\title{
JOGOS DE PAPÉIS (RPG) EM DIÁLOGO COM A EDUCAÇÃO AMBIENTAL: APRENDENDO A PARTICIPAR DA GESTÃO DOS RECURSOS HÍDRICOS NA REGIÃO METROPOLTTANA DE SÃO PAULO
}

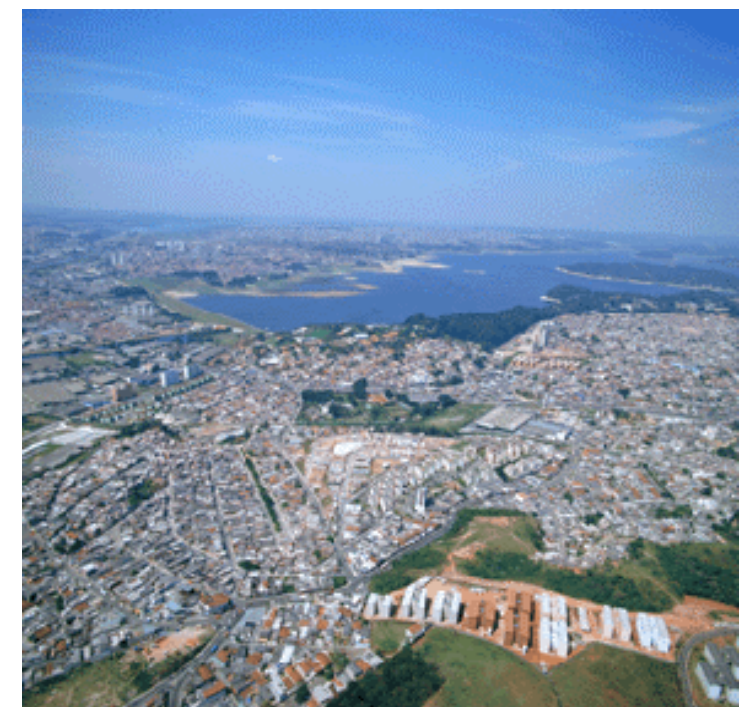

MARIA EUGÊNIA SEIXAS DE ARRUDA CAMARGO

Dissertação apresentada ao Programa de PósGraduação em Ciência Ambiental - PROCAMUSP da Universidade de São Paulo, como parte dos requisitos para obtenção do título de Mestre em Ciência Ambiental.

ORIENTADOR: Prof. Dr. Pedro R. Jacobi

São Paulo 


\section{FOLHA DE APROVAÇÃ̃o}

\section{Autor: MARIA EUGÊNIA SEIXAS DE ARRUDA CAMARGO}

Título: "Jogos de papéis (RPG) em diálogo com a Educação Ambiental: aprendendo a participar da gestão dos recursos hídricos na região metropolitana de São Paulo"

Dissertação defendida e aprovada em ___ _ _ _ _ _ pela comissão julgadora:

Coordenador da Área

Presidente da CPG 
Ao meи pai, pelo bom exemplo

À minha mãe, pela alegria de viver

Ao Tarcísio, pela companhia de todo dia 


\section{Num Dia Excessivamente Nítido}

Num dia excessivamente nítido, Dia em que dava a vontade de ter trabalhado muito

Para nele não trabalhar nada, Entrevi, como uma estrada por entre as árvores, O que talvez seja o Grande Segredo, Aquele Grande Mistério de que os poetas falsos falam Vi que não há Natureza, Que Natureza não existe, Que há montes, vales, planícies, Que há árvores, flores, ervas, Que há rios e pedras, Mas que não há um todo a que isso pertença, Que um conjunto real e verdadeiro É uma doença das nossas idéias.

A Natureza é partes sem um todo. Isto é talvez o tal mistério de que falam.

Foi isto o que sem pensar nem parar, Acertei que devia ser a verdade Que todos andam a achar e que não acham, E que só eu, porque a não fui achar, achei.

Alberto Caeiro 


\section{AGRADECIMENTOS}

Ao professor Pedro Jacobi, meu orientador, não só pela orientação, mas pela abertura de tantos caminhos na área ambiental.

A Raphaèle, coordenadora do Projeto Negowat, que embora não tenha sido reconhecida formalmente, foi uma co-orientadora sempre presente ajudando-me no desafio de compreender e aplicar uma metodologia bastante complexa e sobretudo no exercício de pensar cientificamente.

Ao Projeto Negowat pela bolsa de mestrado concedida para a elaboração desta pesquisa.

À toda a equipe do Projeto Negowat, em especial Cesar, Diana, Jaime, Yara, Wanda, Vilma, Bernardo e todos que contribuíram bastante na aplicação e no aprimoramento dos jogos desenvolvidos.

Aos professores Eda Tassara e Marcos Ortiz pelas contribuições no exame de qualificação.

Ao professor Lino de Macedo, pela disciplina Jogos e a dialética em Piaget e pelas conversas, por conseguir explicar conceitos tão complexos de forma tão simples.

Ao professor Paulo de Salles Oliveira, pela disciplina O lúdico e a cultura solidária.

Ao professor Marcos Ferreira Santos e Solange, pela orientação constante desde a Iniciação Científica e pelo exemplo na "práxis" educativa.

À equipe do Instituto Pólis, em especial Vilma Barban, toda a minha admiração, agradeço o privilégio pela possibilidade de aprender e conviver com uma pessoa tão experiente na área social. Ao Luiz, pela pesquisa realizada com os grupos de Parelheiros que muito nos ajudaram a compreender a problemática dos mananciais na RMSP. Renato Cymbalista, Paula Santoro, por cederem o seu tempo refletindo comigo sobre as questões de pesquisa, enriquecendo-as com sua experiência na elaboração e aplicação do Jogo do Estatuto da Cidade, agradeço também pelas indicações dos outros jogos na área de gestão e planejamento urbano.

Aos professores que colocaram suas aulas à disposição para que pudéssemos realizar as sessões de teste de jogo e seus alunos que participaram com bastante interesse das mesmas: Maria do Socorro Lippi, da Universidade de Santo Amaro (Unisa), Felipa Silveira, da Faculdades Integradas Guarulhos (FIG), Wanda Risso Gunter, da Faculdade de Saúde Pública (USP), Roseli Imbernon, da Universidade de Mogi das Cruzes (UMC).

Aos autores dos jogos brasileiros: Viviane Junqueira do Instituto Ecoar para a Cidadania (SP), Aline Figueiredo de Albuquerque da Ambiens Sociedade Cooperativa (PR), Emily Walsh e Leticia Osorio da Cohre - Centro pelo Direito à Moradia Contra Despejos (RS), pelas conversas e entrevistas concedidas sobre os jogos de papéis brasileiros. 
Aos autores dos jogos internacionais do grupo ComMod: Michel Etienne, Pierre Bommel, Nycolas Faysse pelo curso de formação sobre jogos de papéis com enfoque na modelagem de acompanhamento.

À toda equipe do Projeto Agenda 21 escolar de Embu das Artes: César Pegoraro, Leni Monteiro, Martha Schultz, Silvana Pisani, Indaia Pelosini, em especial Isabel Franco, colega de mestrado que me deu a oportunidade de participar de um projeto tão significativo em Educação Ambiental, de conhecer pessoas tão especiais e ainda partilhou comigo as inquietações da trajetória de pesquisa, tornando-a muito mais rica e menos solitária. Um agradecimento especial ao João, Elaine e todos os professores e professoras das escolas participantes do projeto que muito me ensinaram com sua prática comprometida.

Aos funcionários do Procam: Luciano, Maria José, Gabriela e Marina, pela ajuda nas questões administrativas e institucionais durante todo o mestrado.

Aos colegas de mestrado e doutorado do Procam e da Faculdade de Educação (USP): Maria, Fernando, Ricardo, Marina, Reynaldo, Fabiana, Mariana Viveiros, André, Paulo, César, Fabíola, Sandra Ines, Luciana, Marialina.

Aos professores do corpo docente do Procam por partilharem conosco a complexidade de uma Ciência Ambiental através das disciplinas e seminários.

Aos funcionários da Biblioteca da Faculdade de Educação (FEUSP), por facilitarem muito as nossas consultas e todo o trabalho de pesquisa.

Aos colegas e amigos do CDI (Comitê para a Democratização da Informática) pela partilha dos primeiros momentos do mestrado e pelas reflexões e práticas de um trabalho em Educação para a Cidadania.

Aos mais recentes colegas e amigos do SESC Interlagos, companheiros e companheiras de trabalho.

Aos amigos e amigas de sempre: Kalu, André, Rafa, Joana, Fabíola, Kão, Ju Trindade, Tati Pavão, Shirley, Carlinha, Rodrigo, Beto, Fino, Aninha, Gustavinho, André, Taciana, Eneida, Gabriel, Lúcia, Liss, Mari Fullen, Sachs e tantos mais que não seria possível citar aqui.

À toda minha família, em especial ao meu pai (in memorian), minha mãe, minha avó Gracinha, minha irmã Sylvia, todos os tios e tias, primos e primas, queridos sogros e cunhados, todos que muito contribuíram para a minha formação ao longo de toda a vida, sem os quais esta etapa não teria sido alcançada.

Ao Tarcísio, um agradecimento especial não só pela companhia de todo dia, mas pelo companheirismo em todos os projetos, pela sua capacidade de "pensar em dois", e por me mostrar a possibilidade de uma vida realmente compartilhada. 


\section{SUMÁRIO}

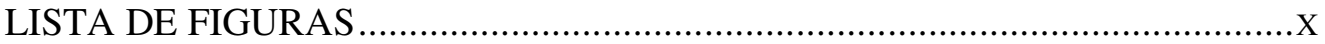

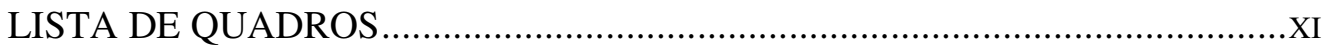

LISTA DE ABREVIATURAS E SIGLAS .................................................

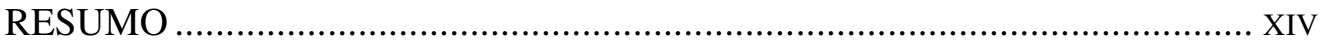

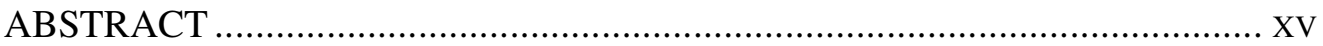

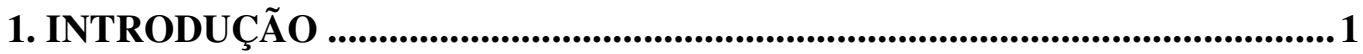

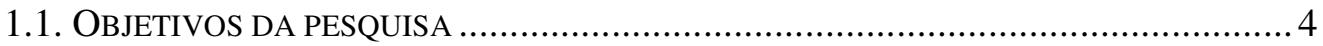

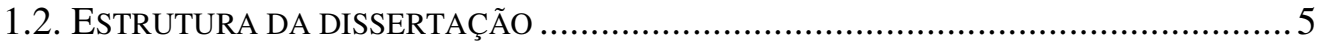

2. A PROBLEMÁTICA ABORDADA NOS JOGOS DE PAPÉIS SELECIONADOS: OS CONFLITOS DA GESTÃO DOS RECURSOS HÍDRICOS NA REGIÃO METROPOLITANA DE SÃO PAULO, OS NOVOS INSTRUMENTOS DE PLANEJAMENTO URBANO E O DESAFIO DA PARTICIPAÇÃO NOS FÓRUNS ESPECÍFICOS....................................................7

2.1. A PROBLEMÁTICA ABORDADA NOS JOGOS DE PAPÉIS SELECIONADOS ................. 7

2.1.1. A gestão inovadora da gestão dos recursos hídricos no Brasil e seus desafios

2.1.2. A questão da gestão dos recursos hídricos na região metropolitana de São

Paulo.

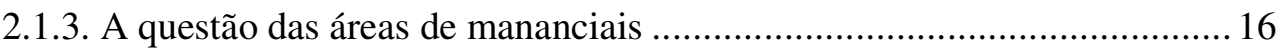

2.2. O Estatuto da CidAdE E A PROPOSTA DA REFORMA URBANA ...................... 19

2.2.1. Os instrumentos do Estatuto da Cidade.............................................. 22

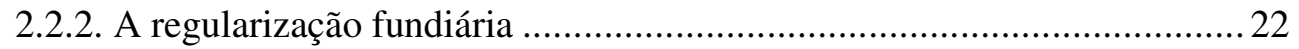

2.3. A QUESTÃO DA PARTICIPAÇÃO DA SOCIEDADE CIVIL NOS COMITÊS DE BACIA E

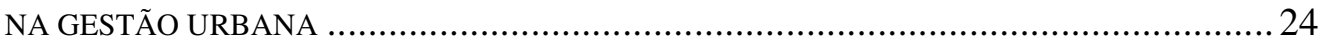

\section{OS JOGOS DE PAPÉIS EM DIÁLOGO COM OS PRINCÍPIOS DA} EDUCAÇÃO AMBIENTAL ...................................................................................27

3.1. OS JOGOS DE PAPÉIS COMO METODOLOGIA DE GESTÃO AMBIENTAL

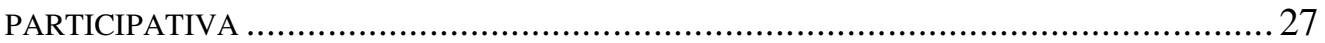

3.1.1. Os desafios da abordagem da modelagem de acompanhamento .............. 31

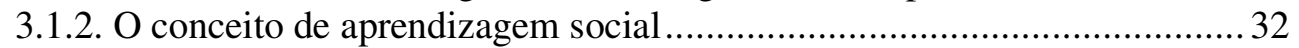

3.1.3. Os desafios da participação............................................................... 35

3.1.4. A Educação Ambiental e a questão da complexidade............................... 38

3.2. A DIVERSIDADE DO CONCEITO JOGO E SUA CLASSIFICAÇÃO .......................... 40

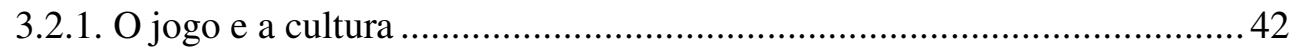

3.2.2. O jogo e a educação............................................................................. 43

3.2.3. Origens e definiç̧̃oes dos jogos de papéis .............................................. 46

3.2.4. A importância do "debriefing” ou análise final do jogo..........................50

3.3. AS CONCEPÇÕES DE EDUCAÇÃO E SEUS DIÁLOGOS COM OS JOGOS DE PAPÉIS: POSSIBILIDADES DA EDUCAÇÃO AMBIENTAL NESTE CONTEXTO .............................51

3.3.1. As concepções de educação e o processo de mediatização da realidade .. 52

3.3.2. Reflexões sobre a Educação Ambiental e suas vertentes ....................... 55

3.3.3. Sobre a criação do termo "Educação ambiental" ......................................63

3.3.4. Algumas considerações sobre as metodologias de EA ........................... 64

4. A PESQUISA REALIZADA: QUESTÕES, HIPÓTESES E METODOLOGIA. APRESENTAÇÃO DOS JOGOS ESTUDADOS...................69 
4.1. A CONSTRUÇÃO DAS QUESTÕES DE PESQUISA E HIPÓTESES

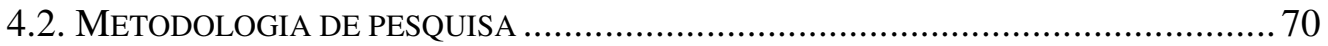

4.2.1. Procedimentos de pesquisa e critérios de análise.................................. 71

4.2.2. Levantamento e comparação de algumas experiências brasileiras que utilizam jogos de papéis na área ambiental e urbana ....................................... 71 4.2.3. Análise das percepções dos jogadores em relação ao Jogo dos Mananciais, protótipo de jogo de papéis com simulação desenvolvido no Projeto Negowat 74

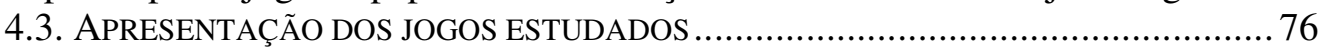

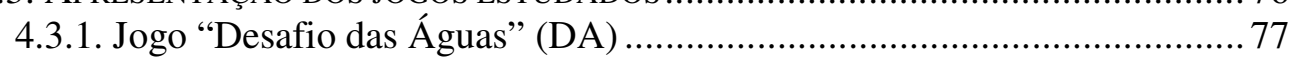

4.3.2. Jogo do "Estatuto da Cidade"(EC) ........................................................ 78

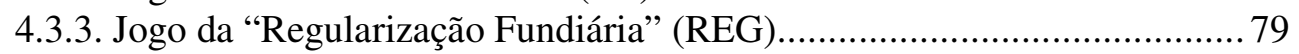

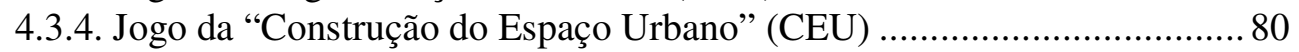

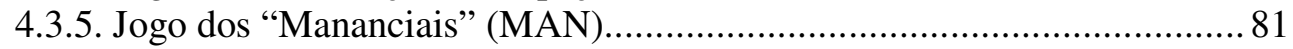

5. EXPERIÊNCIAS BRASILEIRAS DE JOGOS DE PAPÉIS NA ÁREA AMBIENTAL E URBANA: ELEMENTOS PARA PENSAR OS LIMITES E POTENCIALIDADES DESTA METODOLOGIA EM PROJETOS DE EDUCAÇÃO AMBIENTAL ...........................................................................82

5.1. A UTILIZAÇÃO DE JOGOS DE PAPÉIS NA GESTÃO DOS RECURSOS NATURAIS ....... 82

5.2. RESULTADOS E DISCUSSÃO DO LEVANTAMENTO E COMPARAÇÃO DE ALGUMAS EXPERIÊNCIAS BRASILEIRAS QUE UTILIZAM JOGOS DE PAPÉIS NA ÁREA AMBIENTAL E

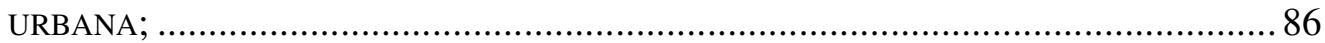

5.2.1. Características em comum das experiências selecionadas ......................8 87

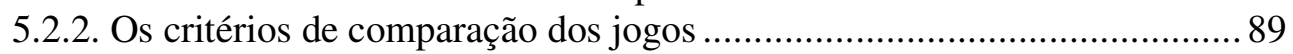

5.2.3. Os resultados da comparação dos jogos ............................................... 91

5.3. DISCUSSÃO - LIMITES E POTENCIALIDADES DOS QUATRO JOGOS DE PAPÉIS

ESTUDADOS EM RELAÇÃO À PROPOSTA DA EDUCAÇÃO AMBIENTAL CRÍTICA ...........99

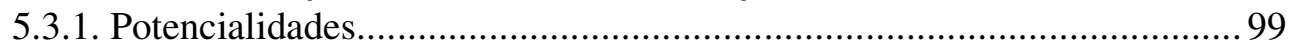

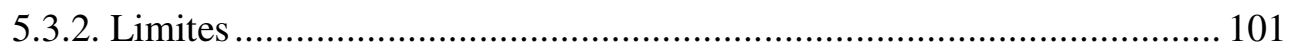

6. ANÁlISE DO JOGO DOS MANANCIAIS A PARTIR DAS PERCEPÇÕES DE UM PÚBLICO DE ESTUDANTES: ELEMENTOS PARA REFLETIR SOBRE AS POSSIBILIDADES E LIMITES DE UM JOGO DE PAPÉIS COM SIMULAÇÃO DE CENÁRIOS....................................................................... 105

6.1. O PROCESSO DE CONSTRUÇÃO DO JOGO E SEUS OBJETIVOS............................ 105

6.2. APRESENTAÇÃO DO JOGO ........................................................................ 107

6.3. SINGULARIDADES DO JOGO DOS MANANCIAIS EM RELAÇÃO AOS ANTERIORES . 109

6.4. ANÁLISE DAS SESSÕES-TESTE DO JOGO DOS MANANCIAIS (MAN): RESULTADOS

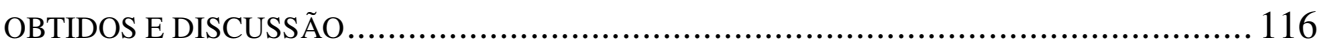

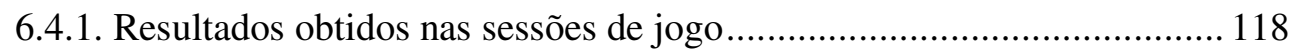

- Aspectos do jogo ............................................................................... 118

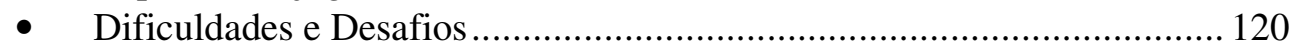

- Aprendizados sobre recursos hídricos ................................................... 123

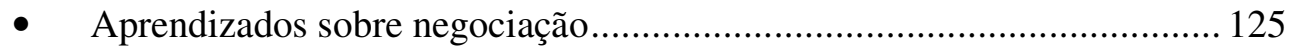

- Aspectos da vivência de reunião do comitê de bacia ................................ 127

- Críticas e sugestões .............................................................................. 129

- Grau de conhecimento dos jogos de papéis (RPG) .................................. 131

- $\quad$ O que entende por jogo de papéis (RPG) ................................................ 132

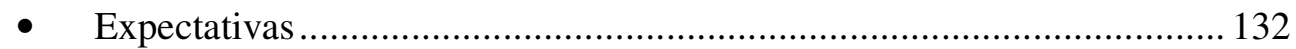

- Conhecimento do Comitê de Bacia............................................................. 133 
- $\quad$ Problemas da gestão dos recursos hídricos nas bacias peri-urbanas......... 134

- $\quad$ Fatores de sucesso de uma negociação na área ambiental ....................... 135

6.4.2. Discussão : Possibilidades e limites de um jogo de papéis com simulação

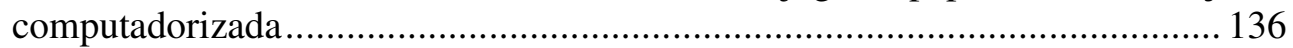

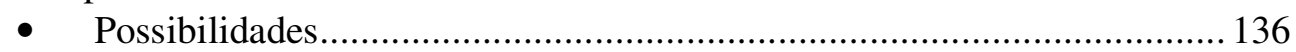

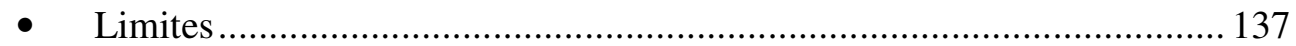

6.5. CONSIDERAÇÕES RELEVANTES SOBRE OUTRO JOGO DE PAPÉIS COM ENFOQUE NA MODELAGEM DE ACOMPANHAMENTO: O PROCESSO TERAGUAS, PERSPECTIVAS DO PROJETO NEGOWAT

7. CONCLUSÕES E CONTRIBUIÇÕES DA PESQUISA PARA NOVOS ESTUDOS ............................................................................................................... 141

8. APÊNDICES E ANEXOS ………................................................................... 146

8.1. EDUCAÇÃO AMBIENTAL, UM BREVE HISTÓRICO ........................................... 147

8.2. ROTEIRO DE QUESTÕES PARA ENTREVISTA COM AUTORES DOS JOGOS SELECIONADOS

8.3. QUESTIONÁRIOS JOGO DOS MANANCIAIS .................................................. 152

9. REFERÊNCIAS BIBLIOGRÁFICAS ...................................................... 154 


\section{LISTA DE FIGURAS}

Figura 1 - Mapa da Mancha Urbana na Bacia Alto Tietê......................................................

Figura 2 - Mapa das Unidades de Gerenciamento de Recursos Hídricos do Estado de SP.....12

Figura 3 - Mapa da Bacia Hidrográfica do Alto Tietê............................................................13

Figura 4 - Mapa do Município de São Paulo : Evolução da população residente segundo os

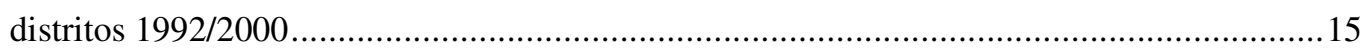

Figura 5 - Mapa das Áreas de Proteção de Mananciais da Bacia do Alto Tietê ......................18

Figura 6 - Oito degraus da participação cidadã..................................................................3

Figura 7 - Visão parcial do Tabuleiro do Jogo “Desafio das Águas”(DA) .............................77

Figura 8 - Visão parcial do Tabuleiro do Jogo "Estatuto da Cidade”(EC) ..............................78

Figura 9 - Visão Parcial do Tabuleiro do Jogo "Construção do Espaço Urbano”(CEU) .......80

Figura 10 - Visão Parcial do Tabuleiro do Jogo dos 'Mananciais"(MAN) .............................81

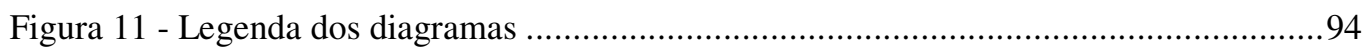

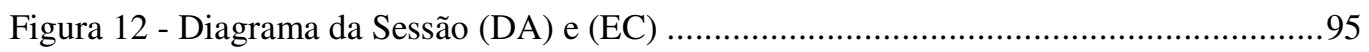

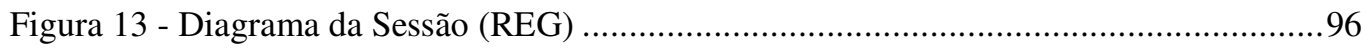

Figura 14 - Gráfico dos 4 RPGs de acordo com os tipos de tarefas .........................................96

Figura 15 - Diagrama da Sessão (MAN) .................................................................... 112

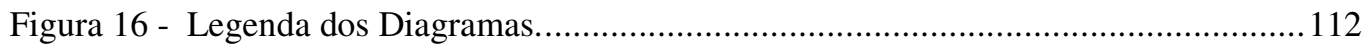

Figura 17 - Gráfico dos RPGs de acordo com os tipos de tarefas......................................113

Figura 18 - Foto ilustrativa de uma sessão do Jogo dos Mananciais....................................117

Figura 19 - Gráfico “Aspectos do Jogo” (Graduação e Pós -Graduação)................................118

Figura 20 - Gráfico 'Dificuldades e Desafios do Jogo”(Graduação e Pós -Graduação) ........ 120

Figura 21 - Gráfico “Aprendizado sobre Recursos Hidricos”(Graduação e Pós -Graduação)

Figura 22 - Gráfico “Aprendizado sobre Negociação”(Graduação e Pós -Graduação).......... 125

Figura 23 - Gráfico "Vivência em reunião do Comitê de Bacia”(Graduação e Pós -Graduação)

Figura 24 - Gráfico “Críticas e sugestõ es ao jogo”'(Graduação e Pós -Graduação) ................129

Figura 25 - Gráfico ‘Grau de conhecimento de jogos - RPG” ..............................................131

Figura 26 - Gráfico ‘O que entende por jogo de papéis - RPG”. ........................................... 132

Figura 27 - Gráfico 'Expectativas” ............................................................................. 132

Figura 28 - Gráfico ‘Conhece o Comitê de Bacia ”.............................................................. 133

Figura 29 - Gráfico ‘Problemas da gestão de Recursos Hídricos” ....................................... 134

Figura 30 - Gráfico ‘Fatores de sucesso de uma negociaç ão ambiental”............................. 135 


\section{LISTA DE QUADROS}

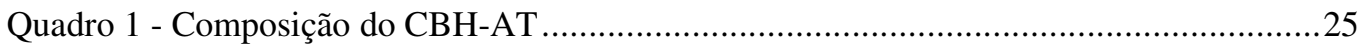

Quadro 2 - Características da EA conservadora e emancipatória. .........................................58

Quadro 3 - Descrição das etapas da pesquisa...................................................................

Quadro 4 - Localização dos Jogos: Espaços de Discussão versus Usos ou Funções ................86

Quadro 5 - Critérios selecionados para a análise dos jogos de papéis estudados.....................89

Quadro 6 - Contexto de utilização dos jogos de papéis estudados..........................................91

Quadro 7 - Os diferentes cenários e funções do suporte visual nos cinco jogos estudados.....92

Quadro 8 - As diferentes formas de organização do tempo de jogo.........................................94

Quadro 9 - Tipos de papéis nos jogos analisados................................................................97

Quadro 10 - Formas de avaliação e o público-alvo ...............................................................98

Quadro 11 - Elementos do cenário no Jogo dos Mananciais (MAN)....................................111

Quadro 12 - Organização do tempo no Jogo dos Mananciais (MAN) ………………..........111

Quadro 13 - Tipos de papéis nos jogos analisados.............................................................114

Quadro 14 - Formas de avaliação no Jogo dos Mananciais em relação ao público-alvo ......114

Quadro 15 - Relação das sessões-teste do Jogo dos Mananciais..........................................116 


\section{LISTA DE ABREVIATURAS E SIGLAS}

\begin{tabular}{|c|c|}
\hline APRM-G & $\begin{array}{l}\text { Área de Proteção e Recuperação dos Mananciais da Bacia Hidrográfica do } \\
\text { Guarapiranga }\end{array}$ \\
\hline $\mathrm{CBH}$ & Comitê de Bacia Hidrográfica \\
\hline CBH-AT & Comitê de Bacia Hidrográfica do Alto Tietê \\
\hline CEFE & Competency based Economies through Formation of Enterprise \\
\hline Cemagref & $\begin{array}{l}\text { Institut de recherche pour l'ingénierie de l'Agriculture et de } \\
\text { l'Environnement }\end{array}$ \\
\hline CEU & Jogo da Construção do Espaço Urbano \\
\hline CIRAD & $\begin{array}{l}\text { Centre de coopération Internationale em Recherche Agronomique pour le } \\
\text { Development }\end{array}$ \\
\hline Cohre & Centro pelo Direito à Moradia Contra Despejos \\
\hline ComMod & Companion Modelling Approach \\
\hline DA & Jogo do Desafio das Águas. \\
\hline DRP & Diagnóstico Rural Participativo \\
\hline EA & Educação Ambiental \\
\hline $\mathrm{EC}$ & Jogo do Estatuto da Cidade \\
\hline EMPLASA & Empresa Paulista de Planejamento Mestropolitano SA \\
\hline FEUSP & Faculdade de Educação da USP, \\
\hline FIG & Faculdades Integradas Guarulhos \\
\hline FSP-USP & Faculdade de Saude Pública da USP \\
\hline FUNDAP & Fundação do Desenvolvimento Administrativo de São Paulo. \\
\hline HarmoniCOP & Harmonising Collaborative Planning \\
\hline IBGE & Instituto Brasileiro de Geografia e Estatística \\
\hline INRA & Institut National de la Recherche Agronomique \\
\hline IPTU & Imposto Predial e Territorial Urbano. \\
\hline MAN & Jogo dos Mananciais \\
\hline MEC & Ministerio da Educação do Brasil \\
\hline NEGOWAT & Negotiating Peri-urban Water Conflicts project \\
\hline ONG & Organização Não-Governamental \\
\hline ONU & Organização das Nações Unidas \\
\hline $\mathrm{PCN}$ & Parâmetros Curriculares Nacionais \\
\hline PMDI & Plano Metropolitano de Desenvolvimento Integrado \\
\hline PMP & Planejamento Municipal Participativo \\
\hline PNUMA & Programa das Nações Unidas para o Meio Ambiente \\
\hline PON & Program on Negotiation at Harvard Law School \\
\hline PROCAM & Programa de Pós Graduação em Ciência Ambiental da USP. \\
\hline PRONEA & Programa Nacional de Educação Ambiental \\
\hline PUC & Pontifícia Universidade Católica \\
\hline REG & Jogo da Regularização Fundiária \\
\hline RMSP & Região Metropolitana de São Paulo \\
\hline RPG & Role Play Game (Jogo de Papéis). \\
\hline SIG & Sistema de Informação Geográfica \\
\hline SIGRH & Sistema Integrado de Gestão dos Recursos Hídricos \\
\hline
\end{tabular}


UGRHI Unidades de Gerenciamento de Recursos Hídricos

UGS

Urban Gaming Simulation

$\mathrm{UMC}$

Universidade de Mogi das Cruzes

UNESCO

UNISA

Organização das Nações Unidas para a Educação, a Ciência e a Cultura

USP

Universidade de Santo Amaro

ZEIS

Universidade de São Paulo.

ZOOP

Zonas Especiais de Interesse Social

Objectives Oriented Project Planning 


\section{RESUMO}

CAMARGO, MARIA EUGÊNIA. (2006). Jogos de papéis em diálogo com a Educação Ambiental: aprendendo a participar da gestão dos recursos hídricos na região metropolitana de São Paulo: São Paulo, 2006. 178p. Dissertação (Mestrado) - Programa de Pós Graduação em Ciência Ambiental PROCAM, Universidade de São Paulo.

Os jogos de papéis (role-playing games) têm sido utilizados em diversos projetos de gestão participativa dos recursos naturais em processos de formação, pesquisa e intervenção de apoio à negociação de conflitos em várias partes do mundo. Uma série de estudos demonstram o potencial destas metodologias para lidar com temas complexos num processo de Educação para a participação, principalmente de atores locais da sociedade civil. Partimos do pressuposto de que os fóruns de negociação de conflitos socioambientais exigem um aprendizado técnico e social para uma participação efetiva da sociedade civil. O objetivo da pesquisa consiste em analisar os potenciais e limites destas metodologias em relação aos princípios da Educação Ambiental. Primeiramente realizamos um levantamento e comparação de experiências brasieliras de formação relacionadas à gestão urbana e ambiental. Em seguida, analisamos de forma mais aprofundada um protótipo de jogo de papéis, com enfoque na modelagem de acompanhamento, que corresponde ao foco do trabalho - O Jogo dos Mananciais. O jogo em destaque trata da problemática da gestão dos recursos hídricos em áreas de mananciais peri-urbanos. Os resultados da análise mostram que o jogo apresenta diversas potencialidades como metodologia de apoio à formação, embora seus limites estejam relacionados à complexidade da ferramenta e ao tempo dispendido na sua elaboração. Além disso, como uma metodologia didática, o jogo de papéis (RPG) deve estar inserido num processo de formação mais amplo.

Palavras-chave: jogo de papéis, negociação de conflitos; educação ambiental, participação. 


\begin{abstract}
CAMARGO, MARIA EUGÊNIA. (2006). Role-playing games and Environmental Education: learning to take part in the water resources management in São Paulo 's metropolitan region, Brazil: São Paulo, 2006. 178p. Dissertação (Mestrado) - Programa de Pós Graduação em Ciência Ambiental - PROCAM, Universidade de São Paulo.
\end{abstract}

Role playing games in natural resources management have recently been tested as training, research and intervention tools all over the world. Various studies point out their potential to deal with complex issues and to contribute on the training processes. We believe that a social learning process is necessary to empower the local communities to take part on the negotiation channels. The objective of this contribution is to briefly analyze the limits and potential of games within environmental education from the critical perspective. The analysis begins by a comparison of four Brazilian experiences, which are "regular" RPGs, developed to deal with the complexity of urban and environmental management. They were used within an educational process focusing on either local communities or technicians. The comparison of these experiences is based on (i) an analysis of the materials (game support) provided by the developers, (ii) interviews with authors and game developers and (iii) participation in game sessions whenever possible. Then we deeply analyze the RPG (Jogo dos Mananciais), the research focus. This game is a prototype based on Companion Modeling Approach. It deals with the water resources management in peri-urban catchments. The results show role-playing games have many possibilities as a training methodology, however their limits are related to the complexity of the toll. So, the RPG must be inserted into a wider educational process.

KEYWORDS: role-playing games; water management; urban management; group processes; environmental education 


\section{INTRODUÇÃO}

"A educação para a cidadania representa a possibilidade de motivar $e$ sensibilizar as pessoas para transformar as diversas formas de participação em potenciais fatores de dinamização da sociedade e de ampliação do controle social da coisa pública, inclusive pelos setores menos mobilizados. Trata-se de criar as condições para a ruptura com a cultura política dominante e para uma nova proposta de sociabilidade baseada na educação para a participação"

(JACOBI,2001)

Por mais que se verifiquem diversos avanços na democratização dos fóruns de tomada de decisão na área ambiental, através da criação de conselhos e estruturas mais participativas de discussão, a questão da participação dos vários setores da sociedade civil ainda é um desafio a ser alcançado.

Partimos do pressuposto que a negociação de conflitos ambientais requer não apenas um conhecimento técnico sobre o assunto, mas também um aprendizado social que envolve as interações dos diversos setores e a busca de uma visão compartilhada do problema. Tais questões envolvem habilidades de negociação, entendimento da situação, posicionamento e tomada de decisão. Trata-se de uma participação qualificada que envolve habilidades de alta complexidade, principalmente para a sociedade civil em seus segmentos mais marginalizados e de baixo nível de instrução.

Neste sentido, formas tradicionais de formação e materiais didáticos simplificados como manuais ou cartilhas já não são suficientes para uma efetiva formação das comunidades e lideranças dos movimentos sociais. No âmbito da educação para a cidadania e da própria educação ambiental, surgem algumas metodologias participativas de maior complexidade que vão atuar no sentido de promover um aprendizado para a participação.

Em tal contexto situam-se os jogos de papéis ${ }^{1}$ ou role-playing-games (RPG), metodologias que agregam o aspecto lúdico do jogo e a interpretação de personagens

\footnotetext{
${ }^{1}$ Jogos de papéis é uma tradução do inglês “role -playing games" que significa jogos de interpretação nos quais os jogadores-personagens devem discutir e tomar decisões sobre uma situação-problema proposta.
} 
presente no teatro, promovendo a vivência dos vários aspectos de uma situação-problema proposta.

Essas metodologias têm sido desenvolvidas em diversos projetos de formação, pesquisa e intervenção relacionados à gestão dos recursos naturais, principalmente em nível internacional. $\mathrm{Na}$ área de formação, os jogos de papéis podem ser utilizados tanto na Educação formal, quanto na educação não-formal. Na primeira aparecem em cursos de formação sobre técnicas de negociação para profissionais das áreas de Direito, Administração de Empresas, Relações Internacionais, entre outras; já na segunda, em projetos sociais de educação popular e formação de grupos da sociedade civil. Na área de pesquisa, dinâmicas de grupo que envolvam jogos de papéis são utilizadas para a coleta de dados, buscando um entendimento maior dos conflitos e das relações sociais que permeiam determinados conflitos.Em projetos de intervenção, o jogo de papéis é utilizado no próprio processo de negociação, buscando uma visão compartilhada do problema ou melhores formas de comunicação entre os envolvidos no processo (BOISSAU;CASTELLA, 2003).

O interesse deste estudo situa-se nas experiências de formação no âmbito da educação não-formal, que utilizem os jogos de papéis em projetos de capacitação de lideranças e movimentos sociais; assim como no processo de elaboração e avaliação de um jogo de papéis sobre a problemática da gestão dos recursos hídricos em áreas de mananciais periurbanos, na região metropolitana de São Paulo (RMSP).

No contexto metropolitano, especialmente na sub-bacia da Guarapiranga, os conflitos socioambientais relativos à gestão dos recursos hídricos situam-se na tensão entre a conservação de áreas de proteção aos mananciais para abastecimento público e a falta de uma política habitacional que impeça a ocupação do solo nessas áreas para fins de moradia popular. $\mathrm{O}$ crescimento da ocupação urbana nas regiões periféricas da cidade de São Paulo, verificado principalmente nos setores de baixa renda da população, tem sido uma das principais causas da degradação dos reservatórios, devido à poluição proveniente da falta de tratamento dos esgotos. Neste sentido, um dos problemas mais 
críticos apontados na gestão dos recursos hídricos na região metropolitana de São Paulo (bacia do Alto Tietê), refere-se ao uso e ocupação do solo (PORTO, 2003).

A pesquisa está inserida no Projeto Negowat ${ }^{2}$. - Facilitando a negociação sobre a gestão da terra e da água em sub-bacias peri-urbanas na América Latina: combinando modelagem multi-agente com jogo de papéis, um projeto de pesquisa interdisciplinar que agrega diversas instituições de pesquisa nacionais e internacionais, dentre elas o Procam (Programa de Pós-Graduação em Ciência Ambiental), onde alunos de Mestrado e Doutorado desenvolvem pesquisa vinculada ao projeto sob a coordenação do Prof. Pedro Jacobi. O objetivo principal do Projeto Negowat é desenvolver e testar ferramentas de apoio à negociação de conflitos sobre água e solo em áreas peri-urbanas. O Projeto, coordenado pela pesquisadora Raphaèle Ducrot, ligada ao CIRAD, desenvolve pesquisas em duas áreas de estudo da região metropolitana de São Paulo (sub-bacias Alto-Tietê/ Cabeceiras e Guarapiranga) e ainda numa área localizada na região de Cochabamba, na Bolívia.

O Projeto Negowat trabalha basicamente com os seguintes referenciais teóricos: (i) o conceito de “Aprendizagem Social”'(Social Learning) (PAHL-WOSTL;HARE, 2004) que pressupõe uma integração dos aspectos sociais e técnicos e de suas inter-relações no tratamento de conflitos socioambientais; (ii) o "Enfoque da Modelagem de Acompanhamento" (Companion Modelling Approach-ComMod) (BARRETEAU et al, 2003) que entende os jogos de papéis e os modelos multi-agente como ferramentas promissoras no tratamento das questões ambientais, à medida que possibilitam a representação partilhada do conflito e a percepção da complexidade inerente às questões.

Nesta pesquisa pretendemos estabelecer um diálogo entre tais abordagens acima citadas e os príncipios da Educação Ambiental em sua vertente mais crítica e progressista a partir da análise da metodologia do jogo de papéis.

\footnotetext{
${ }^{2}$ Negowat: Projeto de cooperação internacional que pretende desenvolver e testar metodologias de jogos de papéis associadas à modelagem multi-agente para apoio a negociação de conflitos relativos ao uso do solo e da água em bacias peri-urbanas. (www.negowat.org)
} 


\subsection{OBJETIVOS DA PESQUISA}

O objetivo geral da pesquisa consiste em analisar os alcances e limites dos jogos de papéis na área ambiental, no que se refere a contribuir na capacitação sobre possíveis concertações e negociações em torno dos conflitos socioambientais em projetos de educação ambiental e educação não-formal em sentido mais amplo.

Como objetivos específicos temos dois que correspondem às duas etapas nas quais está dividida esta pesquisa:

1. Sistematizar e comparar algumas experiências brasileiras na área ambiental e urbanística que utilizam o jogo de papéis como ferramenta didática de formação no âmbito da educação não-formal;

2. Analisar um jogo de papéis, intitulado "O Jogo dos Mananciais", desenvolvido e testado durante o Projeto Negowat, no contexto de desenvolvimento de uma metodologia de formação e apoio à negociação de conflitos socioambientais na área da gestão dos recursos hídricos.

O foco do trabalho incide sobre o jogo de papéis - "O Jogo dos Mananciais", uma vez que tivemos a oportunidade de participar de todo o processo de adaptação do jogo para fins didáticos e das sessões de teste do mesmo que serviram de base para a análise do jogo. Vale ressaltar que este jogo é um protótipo de jogo de papéis com enfoque na modelagem de acompanhamento. Como tal, permite-nos um destaque para seus potenciais e limites em relação aos jogos de papéis tradicionais, os quais foram sistematizados no âmbito do resgate de experiências brasileiras, considerando as limitações inerentes a um protótipo.

O Jogo dos Mananciais, analisado em detalhe neste estudo, pode ser considerado como um primeiro exemplo de um jogo de papéis pautado no conceito de aprendizado social que agrega componentes da modelagem multi-agente ao jogo de papéis tradicional. Desta forma, o jogo encontra-se acoplado a um modelo informatizado que permite a simulação de cenários, integrando num mesmo modelo a dinâmica de transformações ambientais e 
algumas das regras das relações sociais e interações estabelecidas entre os agentes envolvidos na situação-problema.

\subsection{ESTRUTURA DA DISSERTAÇÃO}

Esta dissertação apresenta a seguinte estrutura:

No primeiro capítulo apresentamos a descrição geral da pesquisa, com uma introdução do problema, os objetivos, a estrutura da dissertação e o contexto no qual esta se insere.

No segundo capítulo, explicita-se a problemática abordada nos jogos de papéis selecionados, mapeando assim o contexto no qual tais metodologias aparecem. Nesta parte tratamos basicamente das questões socioambientais relacionadas à gestão participativa dos recursos hídricos e da gestão urbana no que concerne aos desafios de uma participação efetiva da sociedade civil em seus mais diversos setores. Os jogos de papéis, neste contexto, trazem possibilidades de uma metodologia de apoio à negociação de conflitos e de uma ferramenta didática voltada à educação para a participação.

No terceiro, discute-se o referencial teórico que orienta o estudo. A proposta é estabelecer um diálogo entre a temática dos jogos de papéis no contexto da gestão dos recursos naturais e os princípios da Educação Ambiental em sua vertente mais crítica.

No quarto capítulo, explicitamos as questões de pesquisa e as hipóteses que orientam o estudo e a metodologia de pesquisa. Em relação aos procedimentos, o estudo foi dividido em duas etapas: i) o levantamento e comparação de algumas experiências brasileiras de jogos de papéis na área e ii) a análise do monitoramento de um jogo de papéis desenvolvido no âmbito do Projeto Negowat - O Jogo dos Mananciais. Para a primeira etapa da pesquisa, utilizamos a análise do material de jogo, relatórios, entrevistas com os autores e a observação participante de uma sessão de jogo quando possível. Na segunda, foram aplicados questionários aos jogadores ao final das sessões de jogo, a fim de buscar as percepções dos jogadores sobre o jogo. Ainda neste capítulo, apresentamos os jogos estudados para aproximar o tema do leitor. 
No quinto capítulo são apresentados os resultados da primeira etapa da pesquisa e a discussão dos mesmos. No sexto, discutimos os resultados das sessões de teste do Jogo dos Mananciais, que constitui o foco do trabalho, analisando-o e destacando seus limites e potenciais em relação aos jogos de papéis tradicionais sintetizados na primeira etapa de pesquisa. Ainda nesta parte apresentamos brevemente o estado de avanço do Projeto Negowat, no que concerne aos outros jogos de papéis em desenvolvimento, atentando para o processo de aprimoramento de tais ferramentas.

Finalizamos o trabalho com algumas conclusões sobre a temática estudada e contribuições da pesquisa para refletir em trabalhos futuros na área. 


\section{A PROBLEMÁTICA ABORDADA NOS JOGOS DE PAPÉIS SELECIONADOS: OS CONFLITOS DA GESTÃO DOS RECURSOS HÍDRICOS NA REGIÃO METROPOLITANA DE SÃO PAULO, OS NOVOS INSTRUMENTOS DE PLANEJAMENTO URBANO E O DESAFIO DA PARTICIPAÇÃO NOS FÓRUNS ESPECÍFICOS}

\subsection{A PROBLEMÁTICA ABORDADA NOS JOGOS DE PAPÉIS SELECIONADOS}

O presente capítulo tem como objetivo apresentar o contexto no qual está inserida a problemática socioambiental urbana de que tratam os jogos de papéis selecionados para este estudo. Tais jogos abordam questões relativas a dois grandes eixos temáticos: de um lado, a problemática dos mananciais peri-urbanos na região metropolitana de São Paulo e a questão da participação no sistema de gestão dos recursos hídricos (SIGRH), e de outro, os novos instrumentos de gestão e planejamento urbano propostos pela legislação do Estatuto da Cidade ( lei federal 10.257/2001) com o objetivo de garantir a função social da mesma e o desafio da participação da sociedade civil no planejamento e na gestão urbana.

Apesar da aparente divisão temática, os assuntos abordados nos jogos de papéis encontram-se intimamente relacionados quando se trata de questões socioambientais nas áreas de mananciais peri-urbanos. Nestes locais, principalmente na região metropolitana de São Paulo (RMSP), a grande problemática situa-se na tensão entre a conservação ambiental e o crescimento urbano periférico que envolve a necessidade de ocupação do solo para fins de habitação popular em condições precárias.

Objetivamos com este capítulo discutir as possibilidades e os desafios que os novos canais de participação propostos tanto na gestão dos recursos hídricos, quanto no planejamento urbano, apresentam, em relação à participação da sociedade civil nos fóruns específicos.

Vale ressaltar que não se trata de um estudo detalhado da problemática em questão, já que por ser um tema bastante complexo, exigiria um estudo específico e mais aprofundado. $\mathrm{O}$ que se pretende aqui é apresentar o contexto no qual as metodologias, no 
caso os jogos de papéis foram desenvolvidas como subsídios para uma educação popular e ambiental. Neste sentido, os temas acima citados trazem a questão do desafio da participação dos vários atores, em especial da comunidade local, perante aos novos arranjos institucionais e de uma necessária formação para uma participação qualificada e efetiva.

A dinâmica de "urbaniza ção por periferias" produziu um ambiente urbano segregado e altamente degradado com graves conseqüências para a qualidade de vida de seus habitantes, principalmente na região metropolitana de São Paulo (JACOBI, 2000).

Raquel Rolnik, ao resgatar a história da legislação urbana na cidade de São Paulo, demontra a existência de uma cidade ilegal construída à margem da cidade legal que acaba por configurar regiões de cidadania limitada em face a regiões de plena cidadania (ROLNIK, 2003).

Um dos grandes problemas ambientais da cidade de São Paulo, em relação à questão da água é a ocupação das áreas de mananciais. Os loteamentos clandestinos, os bairros irregulares e as favelas estão instalados nestas áreas, comprometendo seriamente a qualidade da água para a população e a qualidade de vida destas pessoas que ali moram em condições bastante precárias. A mancha urbana da cidade de São Paulo estendeu-se praticamente por toda a bacia do Alto Tietê, como pode ser visto na figura a seguir. 
Figura 1 - Mapa da Mancha Urbana na Bacia Alto Tietê

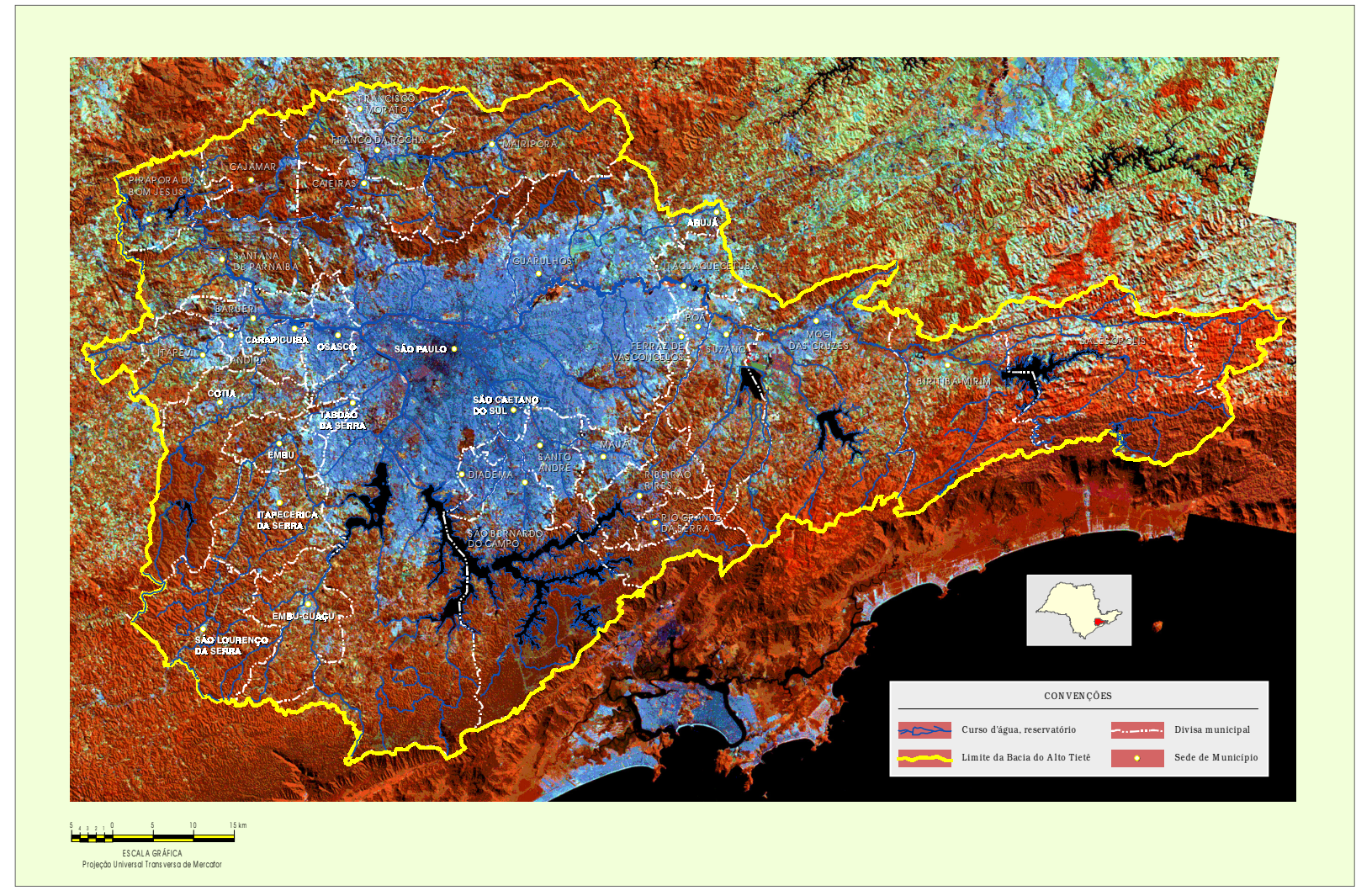

Fonte: Comitê da Bacia Hidrográfica do Alto Tietê

\subsubsection{A gestão inovadora da gestão dos recursos hídricos no Brasil e seus desafios}

No Brasil a legislação relativa ao aproveitamento dos recursos hídricos inicia-se com o Código das Águas, de 1934, que já considerava a água como um bem público. A Constituição de 1988 atribui ao Estado o papel de instituir um sistema nacional de gerenciamento de recursos hídricos com a definição de critérios de outorga de direitos de uso. No entanto, depois de um longo período de discussão, o Congresso aprova no final de 1996 um Projeto de Lei Nacional de Recursos Hídricos que vai instituir a Política Nacional de Recursos Hídricos com a Lei 9433 de 1997, mais conhecida como a 'Lei das Águas"( JACOBI, 2001). 
A partir dessa Política, as discussões em torno da água deixam de ser apenas assuntos técnicos para especialistas e passam a envolver também os usuários e as comunidades. Dá-se então a criação de um sistema de gerenciamento descentralizado e participativo, estruturado em colegiados, em que o Comitê de Bacia será o principal fórum de discussão e tomada de decisão. O fórum pressupõe a participação do Poder público nos vários níveis, dos usuários e das comunidades locais.

A bacia hidrográfica passa então a ser a unidade de gestão territorial, rompendo as tradicionais fronteiras físico-políticas dos estados e municípios, exigindo uma interação entre os vários setores.

A Lei 9433 prevê ainda os seguintes instrumentos para que seja aplicada a Política Nacional dos recursos hídricos:

1) Os Planos de bacia;

2) o enquadramento dos corpos de água em classes, segundo os usos preponderantes da água;

3) a outorga dos direitos de uso de recursos hídricos;

4) a cobrança pelo uso de recursos hídricos;

5) a compensação a municípios;

6) o Sistema de Informações sobre Recursos Hídricos.

De acordo com o artigo 33 desta mesma lei, integram o Sistema Nacional de Gerenciamento de Recursos Hídricos os seguintes órgãos:

I. o Conselho Nacional de Recursos Hídricos;

II. os Conselhos de Recursos Hídricos dos Estados e do Distrito Federal;

III. os Comitês de Bacia Hidrográfica;

IV. os órgãos dos poderes públicos federal, estaduais e municipais cujas competências se relacionem com a gestão de recursos hídricos;

V. as Agências de Água. 
O novo sistema prevê uma gestão integrada e descentralizada da água e de seus usos múltiplos e requer negociações entre órgãos de diferentes níveis de governo (federal, estadual e local), usuários e a sociedade civil organizada é, portanto, um sistema inovador de planejamento e gestão participativa (JACOBI,2001).

No entanto, o desafio da participação efetiva de todos os segmentos nos comitês de bacia ainda é algo a ser alcançado, a inclusão de fatores não apenas técnicos, mas também de caráter político, econômico e cultural tornam o processo bem mais complexo. As relações de poder continuam presentes e a importância do corpo técnico-científico ainda é colocada em primeiro plano, fatores que limitam o envolvimento pleno da comunidade nas reuniões dos Comitês. Há uma certa confusão na legislação, pois ao mesmo tempo em que abre os espaços de participação, pressupõe um acesso às informações técnicas que nem sempre estão disponíveis ao alcance de todos os atores envolvidos (JACOBI,2001).

No Estado de São Paulo, a Lei estadual de Recursos hídricos 7663/91 define a divisão do estado em 22 Unidades de Gerenciamento de Recursos Hídricos (UGRHI) e os Comitês de Bacia Hidrográfica (CBH) são organizados de acordo com a área de abrangência. 
Figura 2 - Mapa das Unidades de Gerenciamento de Recursos Hídricos do Estado de SP

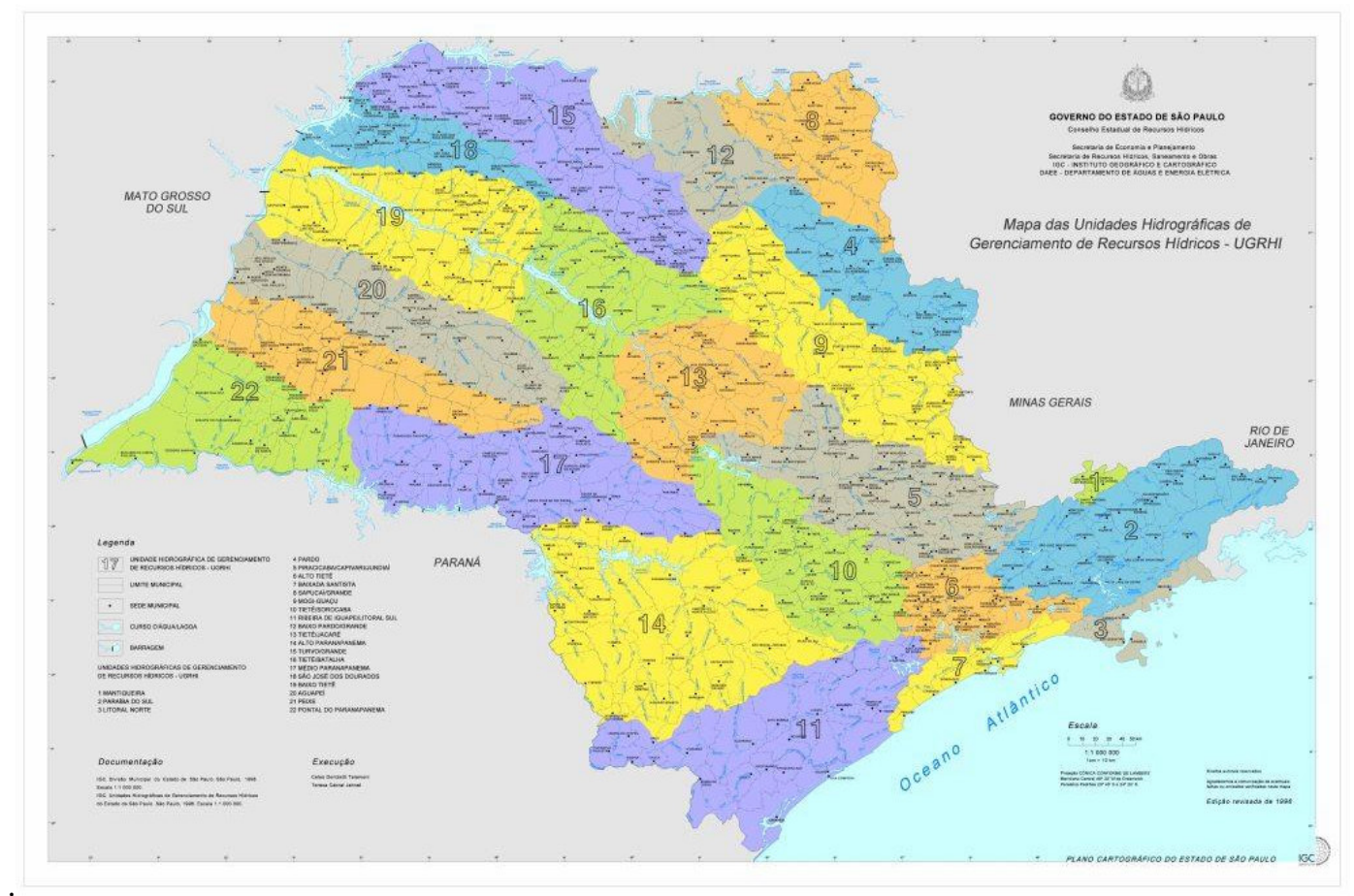

Fonte: Instituto Geográfico Cartográfico de São Paulo

A Bacia do Alto Tietê inclui 35 municípios num território semelhante ao da região metropolitana de São Paulo. O Comitê de Bacia do Alto Tietê está sub-dividido em cinco subcomitês: Juqueri-Cantareira, Pinheiros-Pirapora, Cotia-Guarapiranga e BillingsTamanduateí e Tietê-cabeceiras. Cada sub-comitê apresenta uma estrutura semelhante à do Comitê (JACOBI, 2001). 
Figura 3 - Mapa da Bacia Hidrográfica do Alto Tietê

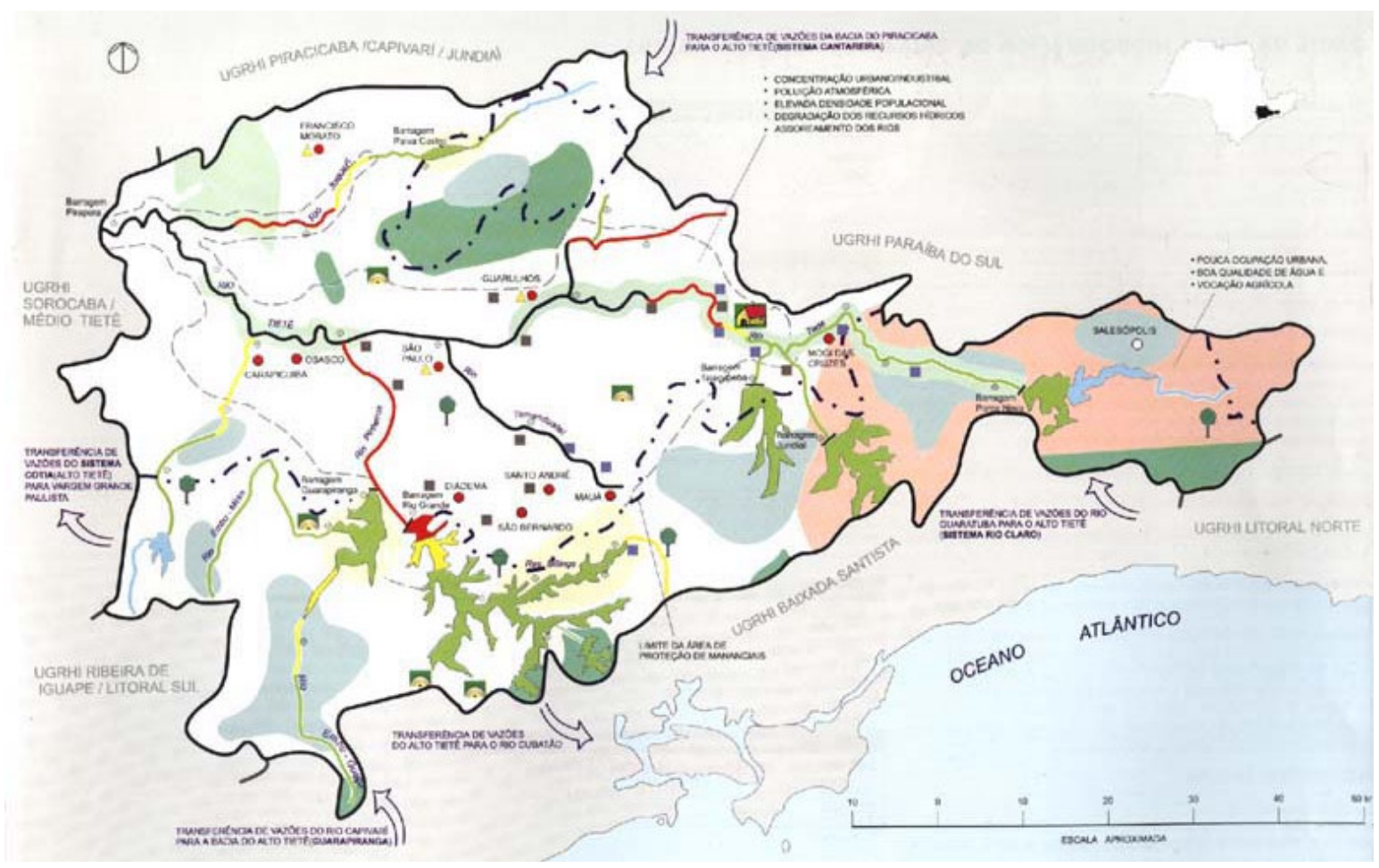

Fonte: Comitê da Bacia Hidrográfica do Alto Tietê

A área urbanizada corresponde a $37 \%$ da área da bacia, a bacia ocupa apenas 2,7\% do território paulista mas concentra quase $50 \%$ da população de todo o estado (JACOBI, 2001).

\subsubsection{A questão da gestão dos recursos hídricos na região metropolitana de São Paulo}

A região metropolitana de São Paulo é o maior aglomerado do país e está localizada numa região de cabeceira de rios, o que causa um sério desequilíbrio entre a demanda e a disponibilidade de água, metade da quantidade de água utilizada na RMSP é importada de outra bacia hidrográfica. A forte pressão de urbanização e a demanda de abastecimento por 18 milhões de habitantes caracterizam os principais conflitos (PORTO, 2003). Segundo a autora, o principal problema da bacia do Alto Tietê, onde praticamente se insere toda a RMSP, diz respeita à ocupação do solo que ocasiona a 
poluição dos córregos e reservatórios, devido à falta de tratamento e coleta dos esgotos e ao despejo de resíduos sólidos nos corpos d’água.

A qualidade de vida da população que vive nas áreas mais degradadas é seriamente comprometida, pois esta é a que mais sofre com os efeitos de degradação ambiental. As principais represas do sistema Alto Tietê: Billings e Guarapiranga são bastante afetadas por esses problemas devido ao elevado crescimento urbano nas áreas periféricas do município de São Paulo que correspondem às áreas de proteção aos mananciais.

A crescente especulação imobiliária, a diminuição da renda dos chefes de família, e as elevadas taxas de crescimento urbano nas classes mais pobres causam uma espécie de expulsão das populações de baixa renda do centro para a periferia, com uma crescente demanda por infra-estrutura urbana. $\mathrm{O}$ aumento do preço da terra urbana é o principal fator que explica o movimento de saída das pessoas do centro para as regiões mais periféricas da cidade, ocupando as áreas de mananciais (BIDERMAN, 2001).

Desta forma, o crescimento demográfico na região periférica de São Paulo é verificado principalmente na população de baixa renda que, por não conseguir suportar o alto custo de moradia no centro da cidade, acaba ocupando as zonas mais periféricas em loteamentos irregulares, de menor custo e com condições bastante precárias de vida. Verificamos no mapa abaixo, a evolução do crescimento demográfico em São Paulo e sua expansão nas áreas periféricas. 
Figura 4 - Mapa do Município de São Paulo : Evolução da população residente segundo os distritos $1992 / 2000$

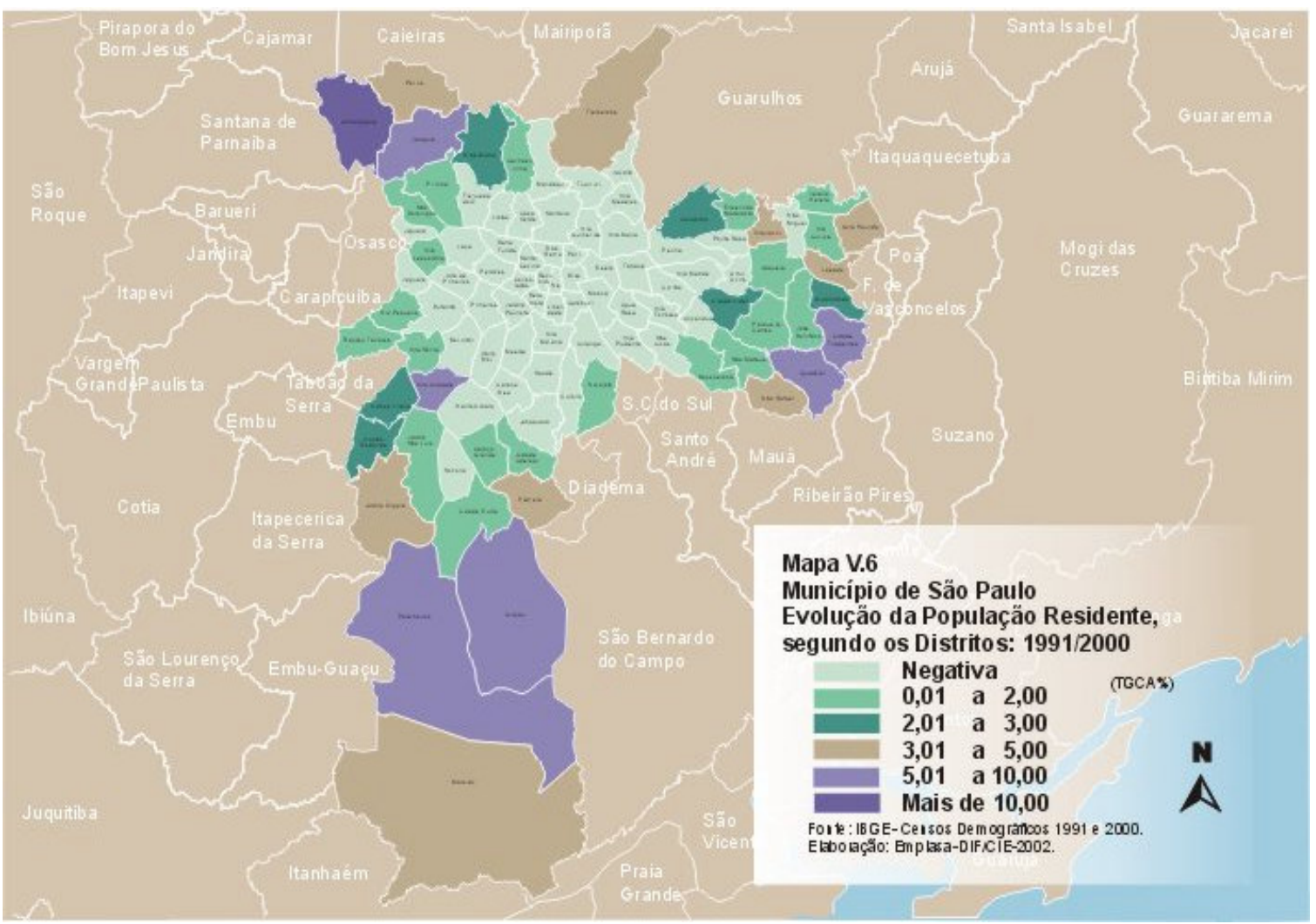

Fonte: IBGE - Censo 1991 e 2000, Elaboração: Emplasa

Os impactos da ocupação humana no ciclo hidrológico acarretam uma série de problemas como a impermeabilização do solo, aumento de enchentes, poluição das águas e redução da disponibilidade hídrica. A poluição do reservatório da Guarapiranga é causada, em parte, pela falta de tratamento dos esgotos domésticos lançados diretamente no sistema. O reservatório Guarapiranga é o segundo sistema produtor de água para o abastecimento público da região metropolitana, responsável pelo abastecimento de cerca de 3 milhões de pessoas ou $20 \%$ da população metropolitana de São Paulo, o que torna a sua poluição altamente preocupante. (CATUNDA, 2000) 


\subsubsection{A questão das áreas de mananciais}

Um dos principais problemas apontados na gestão dos recursos hídricos nas bacias periurbanas refere-se ao uso e ocupação do solo principalmente nas áreas de mananciais (PORTO, 2003).

Neste contexto, os conflitos socioambientais decorrem da tensão entre a conservação de áreas de proteção aos mananciais para abastecimento público e a falta de uma política habitacional que impeça a ocupação do solo nessas áreas para fins de moradia popular. $\mathrm{O}$ crescimento da ocupação urbana nas regiões periféricas da cidade, verificado principalmente nos setores de baixa renda da população, vem causando a degradação ambiental nos reservatórios, devido a poluição proveniente da falta de tratamento dos esgotos, o que compromete a sustentabilidade do abastecimento de água na região.

Na década de 70, com a elaboração do Plano Metropolitano de Desenvolvimento integrado (PMDI), que alertava para o esgotamento dos recursos naturais e pretendia redirecionar o crescimento da metrópole no eixo leste-oeste, foi elaborado, como um dos instrumentos do Plano, a Legislação Estadual de Proteção aos Mananciais (Leis 898/1975 e 1172/1976). Esta legislação delimitava 54\% do território da RMSP como áreas de proteção aos mananciais, estabelecendo padrões para o uso e ocupação do solo de modo a evitar o adensamento populacional e a poluição das águas. As leis de proteção aos mananciais da RMSP proibiram, em grande parte, a implementação de serviços básicos de infra-estrutura e restringiram as formas de ocupação dessas terras, com uma conseqüente desvalorização dos terrenos, que abriu espaço aos loteamentos irregulares e clandestinos (CATUNDA, 2000).

Os moradores das áreas de proteção aos mananciais enfrentam sérias dificuldades na regularização de suas casas e no acesso à serviços básicos como educação, saúde e saneamento, devido à legislação estadual que restringe a ocupação do tipo de habitação popular nestes locais (Leis Estaduais 898/75 e 1172/76). As condições irregulares de

moradia da população residente nestas áreas, acaba por gerar outros tipos de irregularidade como o acesso à água através de redes precárias ou de ligações 
clandestinas. Essas condições sanitárias, juntamente à dificuldade de acesso aos serviços públicos básicos, acabam agravando as condições de saúde e de vida destas populações.

Muito da precariedade de acesso aos serviços públicos deriva das altas restrições impostas pela legislação de proteção aos mananciais, a qual proibia a instalação de serviços básicos nas áreas de proteção, como forma de conter a ocupação.

Com o passar do tempo, tal legislação passou por uma série de revisões até chegar a Lei 9866/97 que apresentava basicamente os mesmos objetivos de conservação e restrição da ocupação, mas que tinha como novidade o fato de estar atrelada ao Sistema de Gerenciamento de Recursos Hídricos (SIGRH), prevendo a gestão integrada e participativa da água, conforme prevista na lei 7663/91 (JACOBI, 2001).

No entanto, as diversas legislações de proteção aos mananciais receberam diversas críticas, uma vez que seu caráter altamente restritivo, causou uma excessiva desvalorização do preço da terra nessas áreas, transferindo o papel de conservação exclusivamente ao proprietário e o Estado ficou omisso. Atualmente o problema da ocupação urbana já consolidada na região deve ser enfrentado através de políticas que pressuponham ações integradas entre as áreas de planejamento urbano e gestão ambiental. Uma lei muito geral, dificilmente poderia ser aplicada, hoje as legislações mais específicas como a lei que define a Área de Proteção e Recuperação dos Mananciais da Bacia Hidrográfica do Guarapiranga - APRM-G, mais conhecida como a Lei Especifica da Guarapiranga são mais factíveis, pois consideram as áreas ocupadas, definindo as zonas onde a urbanização já é consolidada, áreas de risco e áreas de preservação e recuperação ambiental, é específica para a Guarapiranga e não tão geral como a antiga legislação para toda a macrobacia (ANCONA, 2002).

A apropriação e o entendimento dos instrumentos e princípios propostos na Lei Específica da Guarapiranga é de fundamental importância para a comunidade local para que quando for aplicada a lei, esta saiba negociar com maior propriedade suas demandas associadas às questões de moradia e acesso aos serviços básicos de infra-estrutura. 
Quanto ao atendimento por infra-estrutura e acesso aos serviços urbanos básicos na região da Guarapiranga, a taxa de atendimento por rede de água é elevada, cerca de $80 \%$. O sistema público de abastecimento cobre toda a área urbanizada, com exceção dos bairros de Parelheiros e Cipó, no entanto, há muitas redes precárias formadas a partir de ligações clandestinas das linhas de adução da Sabesp, de difícil quantificação e localização. A coleta de esgotos realizada pelo sistema público restringe-se às áreas centrais do município de São Paulo e às áreas de ocupação consolidada. Na porção norte da margem direita da represa, o sistema apresenta $90 \%$ de atendimento, no entanto, ao incluir o distrito de Parelheiros, esse índice cai para 75\%, o que constata a precariedade do sistema na porção sul da bacia. $O$ índice médio de atendimento da bacia de Guarapiranga é de 38\%, o que é ainda muito baixo. (CATUNDA, 2000).

Figura 5 - Mapa das Áreas de Proteção de Mananciais da Bacia do Alto Tietê

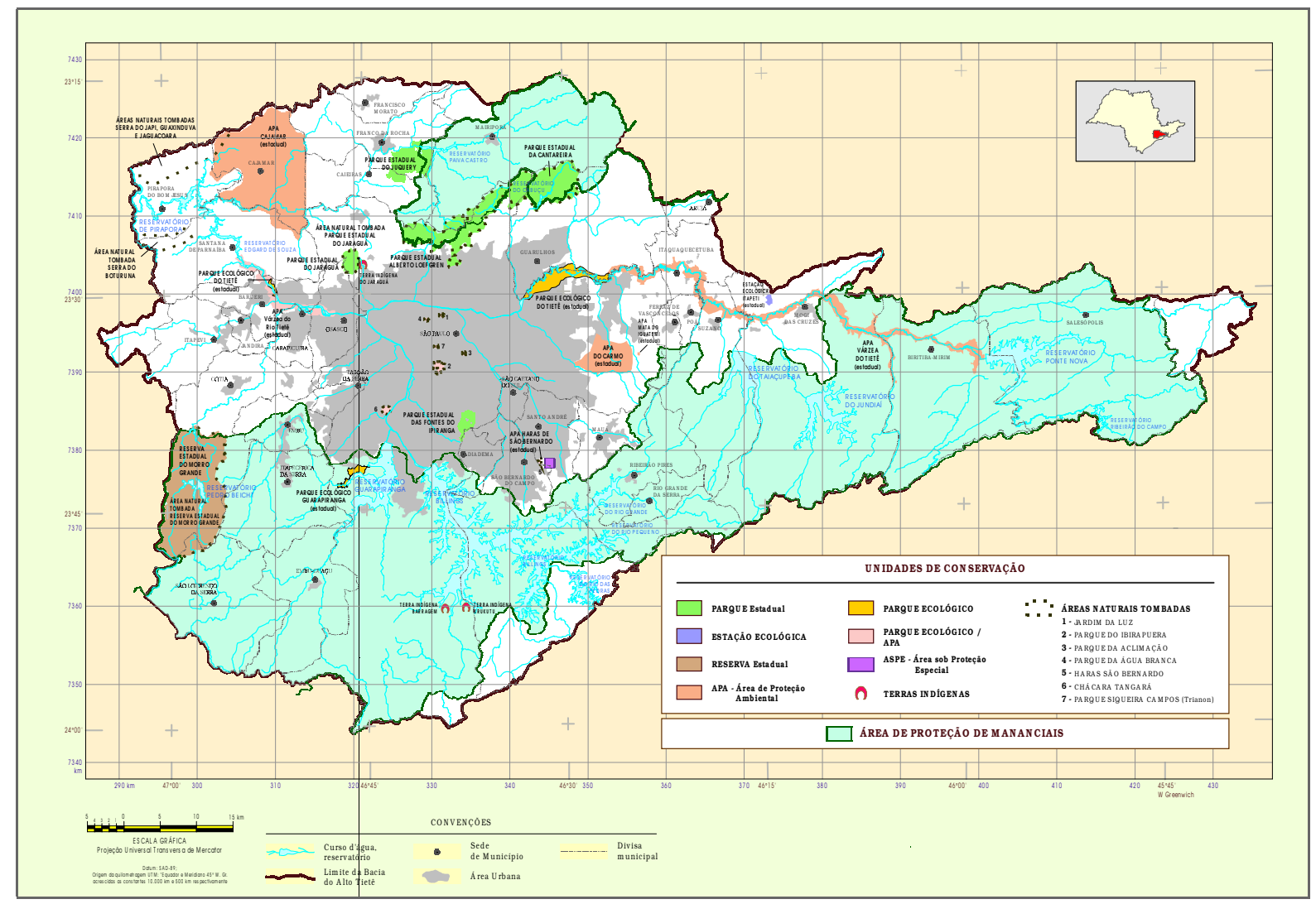

Fonte:Plano de Bacia Alto Tietê, PORTO, 2003. 
Num recente relatório do Banco Mundial intitulado: Água, Redução da pobreza e desenvolvimento sustentável, os autores enfatizam os benefícios para a saúde pública que uma adequada prestação de serviços de saneamento para as populações de baixa renda proporcionaria, promovendo, inclusive uma inclusão social .A poluição das águas causada por um sistema deficiente de coleta e tratamento de esgotos na zona urbana tornou-se um problema fundamental que vem comprometendo a qualidade de vida, os avanços em saúde e o desenvolvimento econômico, principalmente nas grandes áreas metropolitanas (AZEVEDO et al, 2003).

\subsection{O ESTATUTO dA CidAdE E A PROPOSTA DA REFORMA URBANA}

Na questão urbana, o Estatuto da Cidade representa um marco e o produto de muita discussão dos movimentos de moradia em relação à função social da cidade, trazendo instrumentos para possibilitar a regularização fundiária e a criação de zonas de interesse especial, promovendo assim um uso mais democrático da cidade.

"O Estatuto da Cidade é a lei federal de desenvolvimento urbano exigida constitucionalmente, que regulamenta os instrumentos de política urbana que devem ser aplicados pela União, Estados e especialmente pelos Municípios"

(INSTITUTO PÓLIS, 2002)

A rapidez com que se deu a urbanização brasileira trouxe sérios problemas ambientais e sociais: em 1960 a população urbana era 44,7\% do total, no ano 2000 este número passa a $81,2 \%$ do total. As cidades passam então a abrigar imensas desigualdades sociais, a cidade vai crescendo para a periferia, zonas que não tem a menor infra-estrutura e precárias condições de vida, a população de baixa renda acaba ocupando áreas ambientalmente frágeis, como as áreas de mananciais, onde o preço da terra é mais baixo.

Isso caracteriza uma urbanização "selvagem e de alto risco", comprometendo a qualidade ambiental, muitas vezes essa ocupação é até incentivada pelo poder público que cria conjuntos habitacionais muito afastados do centro, a cidade vai crescendo sem qualquer planejamento, de forma caótica, num modelo excludente em que muitos perdem e pouquíssimos ganham (INSTITUTO PÓLIS, 2002). 
O Estatuto da Cidade, Lei federal no 10.257, de 10 de julho de 2001 aparece como uma proposta de reforma urbana, visando identificar a função social da propriedade para uma política urbana mais democrática e redistributiva.

"Parágrafo único. Para todos os efeitos, esta Lei, denominada Estatuto da Cidade, estabelece normas de ordem pública e interesse social que regulam o uso da propriedade urbana em prol do bem coletivo, da segurança e do bem-estar dos cidadãos, bem como do equilíbrio ambiental."

(Estatuto da Cidade, lei federal 10.257/2001, ART $1^{\mathrm{O}}$ )

As diretrizes gerais da legislação estabelecem os princípios que devem orientar a construção da política urbana em todas as instâncias do poder público, a seguir enumeramos alguns destes princípios:

1) garantia do direito a cidades sustentáveis, entendido como direito à terra urbana, à moradia, ao saneamento ambiental, à infra-estrutura urbana, ao transporte e aos serviços públicos, ao trabalho e ao lazer, para as presentes e futuras gerações;

2) gestão democrática por meio da participação da população e de associações representativas dos vários segmentos da comunidade na formulação, execução e acompanhamento de planos, programas e projetos de desenvolvimento urbano;

3) cooperação entre os governos, a iniciativa privada e os demais setores da sociedade no processo de urbanização, em atendimento ao interesse social;

4) planejamento do desenvolvimento das cidades, da distribuição espacial da população e das atividades econômicas do município e do território sob sua área de influência, de modo a evitar e corrigir as distorções do crescimento urbano e seus efeitos negativos sobre o meio ambiente;

5) a oferta de equipamentos urbanos e comunitários, transporte e serviços públicos adequados aos interesses e necessidades da população e às características locais.

Os instrumentos do Estatuto têm como objetivos induzir a ocupação de áreas já dotadas de infra-estrutura, aptas a urbanizar, evitando a expansão e a ocupação de áreas carentes 
de equipamentos e frágeis do ponto de vista ambiental e aumentar a oferta de terra para servir à demanda por moradia existente.

"As inovações contidas no Estatuto situam-se em três campos: um conjunto de novos instrumentos de natureza urbanística voltados para induzir - mais do que normatizar-as formas de uso e ocupação do solo; a ampliação das possibilidades de regularização das posses urbanas, até hoje situadas na ambígua fronteira entre o legal e o ilegal; e também uma nova estratégia de gestão que incorpora a idéia de participação direta do cidadão em processos decisórios sobre o destino da cidade." (INSTITUTO PÓLIS, 2002)

O Estatuto da Cidade estabelece o Plano Diretor como instrumento básico da política de desenvolvimento e expansão urbana, obrigatório para municípios com mais de 20.000 habitantes e também as cidades integrantes de regiões metropolitanas e de áreas de especial interesse turístico. Cabe ao Plano Diretor cumprir a premissa constitucional da garantia da função social da cidade e da propriedade urbana. A elaboração do mesmo deve envolver os diversos setores da sociedade, de forma descentralizada e participativa. O Estatuto prevê ainda uma transformação da cidade de forma mais democrática, visando à superação da lógica patrimonialista, especulativa e predatória que têm se afirmado nas grandes cidades brasileiras.

O problema reside no fato do planejamento urbano e o zoneamento estarem apenas voltados para as classes de média e alta renda e ignorarem a existência de uma grande parcela de mercados destinados às classes de baixa renda. Desta forma vai se construindo uma lógica perversa de cidade que cria áreas reguladas muitas vezes subutilizadas ou os chamados "vazios urbanos" e áreas irregulares que reproduz a precariedade dos assentamentos populares ( INSTITUTO PÓLIS, 2002).

"O objetivo do Plano Diretor não é resolver todos os problemas da cidade, mas sim ser um instrumento para a definição de uma estratégia para a intervenção imediata, estabelecendo poucos e claros princípios de ação para o conjunto dos agentes envolvidos na construção da cidade, servindo também de base para a gestão pactuada da cidade" (INSTITUTO PÓLIS, 2002) 
A concepção de Plano Diretor presente no Estatuto vai além da visão tecnocrática antigamente presente na área urbanística, tratando a cidade e o planejamento urbano em seus aspectos puramente técnicos, mas pressupõe um planejamento integrado à gestão que envolva os aspectos técnicos e políticos. Neste sentido a cidade é composta por um conjunto de agentes que devem "pactuar" os destinos que p retendem para a sua cidade, o seu município.

\subsubsection{Os instrumentos do Estatuto da Cidade}

Além do Plano Diretor, os instrumentos do Estatuto da Cidade dividem-se em três grandes grupos:

1) Instrumentos de indução do desenvolvimento urbano (Consórcio Imobiliário, IPTU progressivo no tempo, Direito de Superfície, Transferência do Direito de Construir, Solo Criado, Operações Urbanas Consorciadas, Direito de Preempção);

2) Instrumentos de regularização fundiária (Usucapião Especial de Imóvel Urbano, Concessão de Uso Especial para Fins de Moradia, Zonas Especiais de Interesse Social -ZEIS);

3) Instrumentos de democratização da gestão urbana (Debates, Audiências e Consultas Públicas, Conferências, Conselho de Desenvolvimento Urbano, Estudo de Impacto de Vizinhança, Gestão Participativa do Orçamento e Iniciativa Popular de Projetos de Lei)

\subsubsection{A regularização fundiária}

A regularização fundiária é uma das grandes questões das áreas urbanas e periféricas nas grandes cidades, principalmente nas áreas de mananciais, onde a maior parte dos lotes e terrenos de pequeno porte são adquiridos de forma irregular.

A regularização fundiária é definida como:

"o processo de intervenção pública, sob os aspectos jurídico, físico e social, que objetiva legalizar a permanência de populações moradoras de 
áreas urbanas ocupadas em desconformidade com a lei para fins de habitação, implicando melhorias no ambiente urbano do assentamento, no resgate da cidadania e da qualidade de vida da população beneficiária”

(INSTITUTO PÓLIS, 2002)

O processo de regularização fundiária é uma diretriz do Estatuto da Cidade que pretende efetivar o direito de moradia de milhões de pessoas que vivem em situação precária e irregular de moradia. A partir da legalização e da urbanização de favelas, loteamentos populares, cortiços, constitui-se um marco legal capaz de garantir os direitos de moradia para a população pobre ou miserável. O processo envolve várias etapas e é um tanto complicado, no entanto surge como uma possibilidade de regularização dos terrenos e uma garantia maior de moradia para a população residente em condições precárias, de acordo com vários critérios mínimos de padrão urbano e zoneamento.

Deve-se ressaltar que o processo de regularização fundiária deve sempre vir acomapanhado de um plano de urbanização e também de políticas públicas fundiárias e imobiliárias sobre o mercado de terras, ampliando a oferta de moradias populares em condições adequadas e o combate à exclusão social de forma mais ampla.

As ocupações irregulares ocorrem em diversas áreas, no que se refere às áreas de preservação ambiental, as mais atingidas são as de mananciais e as margens de rios e córregos. As consequências da ausência de alternativas habitacionais para grande parte da população de baixa renda manifestam-se na ocupação inadequda de áreas ambientalmente frágeis e com diversas restrições .

Nesta perspectiva torna-se difícil pensar separadamente as políticas de gestão urbana em relação às de gestão ambiental, mais especificamente no que concerne à gestão dos recursos hídricos. A complexidade das questões requer novas formas de se conceber e gerir o espaço urbano, em que as formas participativas e pactuadas apresentam maior possibilidade de eficácia. 


\subsection{A QUESTÃo da PARTICIPAÇÃo dA SOCIEDAdE CIVIL NOS COMITÊS DE BACIA E NA GESTÃO URBANA}

A população de baixa renda que mora nas áreas de mananciais muitas vezes não tem acesso aos fóruns instituídos para a gestão dos recursos hídricos seja por uma falta de informação ou porque dificilmente a representação da sociedade civil no comitês de bacia chega às bases dos movimentos populares. Embora a Política Nacional de Recursos Hídricos (Lei 9433/97) em consonância com a legislação estadual de São Paulo determinem que o fórum institucionalizado para a gestão dos recursos hídricos - Comitê de Bacia - deve ter uma representação eqüitativa dos segmentos: Estado, Município e Sociedade Civil, a participação efetiva dos movimentos do segmento sociedade civil ainda é um desafio a ser alcançado (MARTINS, 2001). No que se refere à temática da gestão urbana, a elaboração de um Plano Diretor participativo, no qual todos os cidadãos

estejam habilitados a discutir, como prevê os instrumentos do Estatuto da Cidade, é igualmente um grande desafio.

Torna-se muito difícil falar de sociedade civil de uma maneira geral, uma vez que a sua heterogeneidade vai agregar pessoas muito distintas: desde os níveis socioeconômicos mais elevados, até os movimentos populares e segmentos da população de níveis socioeconômicos bem inferiores.

O Comitê de Bacia do Alto Tietê apresenta 48 vagas igualmente distribuídas entre os setores Estado, Município e Sociedade Civil, para se ter um exemplo da heterogeneidade dos representantes da sociedade civil nos comitês de Bacia, apresentamos a seguir o quadro que ilustra a representação dos segmentos presentes no Comitê Alto Tietê. 
Quadro 1 - Composição do CBH-AT

\begin{tabular}{|c|l|c|}
\hline Segmentos & \multicolumn{1}{|c|}{ Representantes } & No Representantes \\
\hline & $\begin{array}{l}\text { Secretaria de Recursos hídricos,Saneamento e Obras, } \\
\text { Departamento de Águas e Energia Elétrica, Companhia de } \\
\text { Saneamento Básico do Estado de São paulo, Secretaria Estadual } \\
\text { de Meio Ambiente, Fundação Florestal, Companhia de } \\
\text { Tecnologia de Saneamento Ambiental, Secretaria Estadual de } \\
\text { Energia, Secretaria da Educação, Secretaria Estadual de } \\
\text { Economia e Planejamento, Empresa Metropolitana de } \\
\text { Planejamento da Grande São Paulo, Secretaria de Agricultura e } \\
\text { Abastecimento, Secretaria Estadual de Saúde, Secretaria Estadual } \\
\text { de Ciência,Tecnologia e Desenvolvimento Econômico, Empresa } \\
\text { Metropolitana de Águas e Energia e Coordenadoria Estadual de } \\
\text { Defesa Civil }\end{array}$ & \\
Municípios & Três prefeitos de cada sub-comitê e o de São Paulo & \\
\hline Sociedade & $\begin{array}{l}\text { Associações comunitárias (2), Associações industriais(2), } \\
\text { Associações agrícolas(2), Associações de defesa do meio } \\
\text { Cimbiente (3), Associações técnicas especializadas em recursos } \\
\text { hídricos (3), Oraganizações sindicais (1) e Associações } \\
\text { científicas (1) }\end{array}$ & \\
\hline
\end{tabular}

Fonte: JACOBI, KECK, 2003

No entanto a participação efetiva da sociedade civil local dos movimentos sociais de base no Comitê de Bacia, no caso o fórum específico de discussão das questões relativas à gestão dos recursos hídricos, ainda não é uma realidade conquistada.

Da mesma forma a cidade é composta por diversos atores que correspondem aos mais diversos interesses sobre o espaço urbano. Estabelecer canais de debate abertos a todos os segmentos da população é uma das maneiras de fazer com que o Plano diretor, instrumento básico da gestão urbana, não seja apenas uma formalidade ou uma norma, para tornar-se um instrumento de desenvolvimento sustentável nas cidades brasileiras.

A partir deste movimento é possível, através dos instrumentos do Estatuto da Cidade, promover a inclusão social dos segmentos menos favorecidos na questão fundiária em cada município. Neste sentido, desenvolve-se uma 'leitura da cidade", como a possibilidade de inserção dos atores mais marginalizados no processo de planejamento urbano. A discussão do Plano Diretor pode servir de impulso para implantar um 
Conselho da Cidade ou algo equivalente a um fórum permanente de discussão (ROLNIK, 2003).

Neste cenário de novas políticas públicas que pressupõem a participação dos vários atores no processo de gestão dos recursos naturais e de gestão urbana encontramos uma elevada complexidade num contexto de múltiplos interesses e visões distintas sobre uma mesma realidade.

Para alcançar uma gestão participativa mais efetiva nestas instâncias, a sociedade civil em seus mais diversos segmentos deve estar apta a negociar a partir do entendimento das múltiplas visões e dos diversos interesses sobre uma questão socioambiental. Neste contexto, uma Educação que vise formar cidadãos mais conscientes da problemática, de forma a alcançar o seu pleno potencial, deve lidar com as dimensões complexas da sociedade em questão. Assim aparecem as metodologias ou ferramentas didáticas que se constituem como objeto de análise desta pesquisa.

Os jogos de papéis (RPG) apresentam uma discussão a partir de uma vivência da situação-problema e da incorporação de papéis que representam os interesses fundamentais na discussão. Tais metodologias apresentam, como recurso educativo e de apoio à negociação, uma complexidade superior a das tradicionais cartilhas ou manuais didáticos de apoio à formação de grupos. Neste sentido, é de grande relevância analisar os potenciais e os limites destas metodologias como recurso didático num processo não formal de educação para lidar com uma temática socioambiental bastante complexa. 


\section{OS JOGOS DE PAPÉIS EM DIÁlOGO COM OS PRINCÍPIOS DA EDUCAÇÃO AMBIENTAL}

A partir da apresentação da problemática e do contexto no qual os jogos de papéis estão inseridos, pretendemos, neste capítulo, explicitar os referenciais teóricos que orientam a pesquisa.

A idéia é estabelecer a pertinência de um possível diálogo entre uma proposta de gestão ambiental participativa que tem utilizado os jogos de papéis como metodologia e os princípios de uma educação crítica e emancipatória. Por um lado discutem-se alguns dos referenciais que estão na base da concepção de alguns dos jogos de papéis, sob o enfoque da aprendizagem social e da modelagem de acompanhamento. De outro, os que compõem os princípios do campo que se convencionou denominar de Educação Ambiental (EA). A partir das teorias apresentadas, será possível chegar à construção das hipóteses da pesquisa e às diretrizes de análise.

Para fins de organização do texto, o capítulo está dividido em três partes. Na primeira apresentam-se as concepções que embasam o desenvolvimento de jogos de papéis na área ambiental, a questão do aprendizado para a participação e os príncipios e valores da Educação Ambiental em linhas gerais. Na segunda parte, destacam-se as características e princípios do conceito jogo e como os aspectos lúdicos e o jogo aparecem na cultura e na educação. Finalmente, a terceira parte do capítulo traz um aprofundamento nas questões relativas à Educação Ambiental (EA) e às concepções de educação que vão orientar a análise desses jogos ao longo da pesquisa, buscando seus potenciais e limites como recursos didáticos. A partir deste diálogo e do movimento reflexivo apresentado, são formuladas as questões de pesquisa e a construção das hipóteses que orientam o estudo.

\subsection{OS JOGOS DE PAPÉIS COMO METODOLOGIA DE GESTÃO AMBIENTAL PARTICIPATIVA}

$\mathrm{Na}$ área ambiental, atualmente a metodologia dos jogos de papéis é utilizada com diversas finalidades, das quais destacam-se propostas de pesquisa, formação e intervenção (BOISSAU; CASTELLA, 2003). 
Um grupo de pesquisadores tem utilizado tais ferramentas associadas à modelagem multi-agente ${ }^{3}$ com o objetivo de entender a dinâmica complexa de sistemas de gestão ambiental, tanto na área de pesquisa, quanto de formação. Apresentando caráter multidisciplinar, o grupo é constituído por pesquisadores de diversas áreas: agronomia, hidrologia, sociologia, matemática, computação, ecologia, dentre outras. Em sua maior parte, são pesquisadores franceses ligados a várias instituições de pesquisa como CIRAD $^{4}$, Cemagref $^{5}$, INRA $^{6}$ (BARRETEAU et al, 2003). Nesta perspectiva, os jogos de papéis têm sido associados aos modelos multi-agentes numa relação que pressupõe abordar três níveis de interação: 1) uma realidade ou problemática que se pretende abordar, 2) um experimento controlado e 3) um modelo conceitual. Os três níveis de interação formam um triângulo que determina o nível a ser mais evidenciado num contexto de acordo com o foco e os objetivos da ferramenta em desenvolvimento.

Alguns dos princípios de atuação deste grupo foram sintetizados numa carta de intenções relativa à proposta da "Abordagem da Modelagem d e acompanhamento - ComMod", as quais resumidamente propõem através de ferramentas como modelos multi-agente e jogos de papéis os seguintes fatores: (i) a troca de conhecimento, experiências e vivências entre os vários atores envolvidos, incluindo especialistas e leigos; (ii) um reconhecimento mútuo por parte dos pesquisadores e atores locais envolvidos no processo, contemplando a representação das várias partes envolvidas e (iii) a consideração das incertezas e da complexidade inerentes às questões socioambientais na elaboração das ferramentas e metodologias (BARRETEAU, 2003).

O jogo de papéis, neste sentido, é considerado como um modelo, pois corresponde à uma forma de representação da realidade e da problemática em questão. Os modelos não precisam ser necessariamente computadorizados, depende da quantidade de fatores que se pretende abordar. De acordo com o grau de complexidade da ferramenta, o suporte informatizado pode ser ou não necessário. Um modelo pode ser qualquer esquema que

\footnotetext{
3 a modelagem multi-agente consiste em representar num mesmo modelo ou plataforma (software) os processos biofísicos e as dinâmicas sociais de um determinado conflito ou questão (Barreteau, 2003)

${ }^{4}$ CIRAD (Centre de coopération internationale em recherche agronomique pour lê development)

${ }^{5}$ Cemagref (Institut de recherche pour l'ingénierie de l'Agriculture et de l'Environnement)

${ }^{6}$ INRA (Institut National de la recherche agronomique)
} 
prevê uma representação da realidade: um mapa, um sistema de informação geográfica (SIG), um jogo, etc (BARRETEAU, 2003).

Em relação ao desenvolvimento de novas metodologias participativas, o grupo ComMod trabalha há vários anos em projetos de pesquisa sobre a gestão de recursos naturais renováveis combinando o uso da modelagem multi-agente aos jogos de papéis (RPG). Stanislau Boissau e Jean Christophe Castella desenvolveram uma metodologia denominada Samba-Week, a qual combina jogo de papéis, entrevistas e modelagem multi-agente com o objetivo de analisar o sistema de uso e ocupação do solo e gestão local de recursos naturais, na província de Bac Kan, nordeste do Vietnã. No artigo publicado, os autores relatam que o jogo de papéis mostrou-se um instrumento bastante útil para entender a dinâmica ambiental e as relações sociais entre os atores na região estudada (BOISSAU; CASTELLA, 2003).

William Daré em sua análise sobre uma experiência de jogo de papéis acoplado ao modelo multi-agente desenvolvida com agricultores no Senegal, argumenta que o jogo pode ser muito interessante para entender a dinâmica local, pois combina aspectos lúdicos e aspectos da realidade cotidiana dos participantes (DARÉ, 2005).

Michel Etienne enumera uma série de objetivos para os jogos de papéis com enfoque na modelagem de acompanhamento, dentre os quais destacam-se características relativas ao ensino e aprendizagem sobre os conflitos ambientais, tais como a possibilidade de melhorar os conhecimentos sobre determinado assunto, percebendo os vários interesses envolvidos na negociação; estimular as trocas de conhecimento e das representações entre grupos distintos, perceber comportamentos individuais e coletivos e suas implicações na situação proposta (ETIENNE, 2003).

Tais ferramentas são desenvolvidas com o objetivo de compreender e explicitar a complexidade dos sistemas em questão, o que inclui as dimensões ecológicas, sociais e econômicas. O grupo entende o modelo como um objeto intermediário entre o conflito em questão e os atores envolvidos. Neste sentido, os jogos de papéis assim como os modelos multi-agente são entendidos como modelos de representação de uma realidade. 
Conforme citados acima, os objetivos deste grupo em relação à utilização de modelos multi-agente associados aos jogos de papéis vão em duas direções: por um lado entender a complexidade do sistema e por outro, dar suporte ao processo coletivo de tomada de decisão (BARRETEAU, 2003).

Neste processo, é necessário enriquecer o debate em termos técnicos e sociais. A utilização da modelagem, seja através de um modelo multi-agente ou de um jogo de papéis, pretende um reconhecimento mútuo de todos os envolvidos no processo, mais do que uma simplificação da realidade, como verifica-se no tradicional uso de modelos nas áreas social e ambiental (BARRETEAU et al, 2003).

Os pesquisadores que utilizam a abordagem da "modelagem de acompanhamento" atuam em projetos de desenvolvimento e gestão ambiental juntamente aos atores locais. Nesses processos participativos, os diversos pontos de vista devem ser incluídos e contemplados numa perspectiva da aprendizagem social. Nesta abordagem, o conhecimento técnico do problema em questão não é suficiente para uma boa negociação, é preciso enriquecer o debate considerando as relações sociais do contexto. O conceito de aprendizagem social será abordado na seqüência.

A seguir, destacamos alguns dos desafios referentes ao processo de utilização de modelos como ferramentas de apoio à negociação de conflitos ambientais, conforme proposto pelo grupo de pesquisadores ComMod. Estas reflexões serão fundamentais na análise do jogo de pápeis que foi desenvolvido no Projeto Negowat - O Jogo dos Mananciais, o qual corresponde a um protótipo de um jogo de papéis com enfoque na abordagem da modelagem de acompanhamento, ressaltando que este não foi desenvolvido para ser aplicado com os atores locais, mas sim como uma proposta de aprendizado, pois apresenta uma visão acadêmica e um tanto distante da realidade. Portanto é considerado um protótipo de um jogo de papéis com enfoque na modelagem de acompanhamento. 


\subsubsection{Os desafios da abordagem da modelagem de acompanhamento}

Apesar de considerar as questões relativas à complexidade dos sistemas de gestão ambiental e a possibilidade de estabelecer uma visão compartilhada da realidade em questão através de um modelo multi-agente acoplado ao jogo de papéis, a abordagem da modelagem de acompanhamento e, sobretudo da modelagem em geral ainda suscita inúmeras críticas.

A primeira crítica situa-se na base de toda a prática da modelagem pautada nos sistemas de informação. Será que um modelo, por mais completo que seja é capaz de representar uma dinâmica ambiental com as suas múltiplas vertentes: econômica, ecológica, social?

A segunda refere-se à adequação da metodologia ao contexto brasileiro, caracterizado pelo baixo nível de instrução e pela crescente exclusão social das populações de baixa renda. Neste contexto, identificam-se dois principais fatores limitantes: i) o elevado nível de abstração necessário para o entendimento do modelo e, conseqüentemente, o alto nível de escolaridade pressuposto por parte dos atores locais e ii) na exigência de uma infraestrutura computacional necessária para o desenvolvimento das sessões de jogo. Os altos índices de exclusão digital indicam a falta de acesso da maioria da população brasileira às tecnologias da informação, o que poderá ser um fator limitante na capacidade de multiplicação de tais metodologias com a conclusão do Projeto Negowat.

No entanto, quanto mais participativo for desenvolvido o jogo, de forma que as regras do jogo sejam discutidas e compartilhadas por todos, em sintonia com a problemática vivida pelos atores locais e pelo grupo de trabalho, certamente estas limitações poderão ser superadas.

Um outro desafio que se questiona em relação ao enfoque da modelagem de acompanhamento diz respeito à questão da participação. Embora o Sistema Integrado de Gerenciamento dos Recursos Hídricos (SIGRH) pressuponha uma gestão integrada, descentralizada e participativa, a efetiva participação dos atores de base da sociedade civil ainda é uma meta a ser alcançada. A sociedade civil brasileira, principalmente nas 
zonas urbanas, é altamente fragmentada e heterogênea, os fóruns de debate na área ambiental ainda são espaços onde o predomínio da linguagem técnica impede a participação dos atores leigos que fazem parte do sistema. Desta forma, a participação efetiva dos segmentos da sociedade civil vinculados aos movimentos sociais e comunitários enfrenta desafios semelhantes tanto nos comitês de bacia quanto em outros tipos de conselhos, referentes às questões de (1) representatividade; (2) falta de capacitação técnica para intervir de forma mais simétrica nos debates e (3) problemas de ordem financeira que dificultam uma presença contínua (JACOBI, 2001).

Neste sentido, torna-se necessário uma aprendizagem voltada à participação, o que significa uma educação para a cidadania, ou uma Educação Popular e Ambiental (EPA) no seu sentido mais amplo (TASSARA, 2001). Tal educação permitiria aos sujeitos reconhecerem o seu papel de cidadãos, compreendendo o que se discute nestes fóruns para então se envolverem nas questões sócio-ambientais, reivindicando melhores condições de vida e acesso aos espaços democráticos de participação constituídos (DEMO, 2001, JACOBI, 2001).

Da mesma forma que os referenciais da educação para a cidadania, e a proposta de educação popular ${ }^{7}$ são mais familiares ao contexto brasileiro, buscamos refletir sobre a possibilidade de estabelecer um diálogo destes referenciais com o conceito de aprendizagem social. Tal conceito tem sido utilizado por pesquisadores internacionais ligados à temática ambiental para se referir a uma necessidade de um aprendizado que vá além do conhecimento técnico e englobe também as interações e relações sociais de um determinado contexto socioambiental.

\subsubsection{O conceito de aprendizagem social}

De acordo com as críticas referentes aos desafios da participação, é importante destacar o conceito de "aprendizagem social" ( social learning), conceito bastante utilizado pelos pesquisadores que têm refletido sobre a utilização dos jogos de papéis com o enfoque da

\footnotetext{
${ }^{7} \mathrm{O}$ conceito de Educação popular compreende um movimento de "participação na formação e apoio ao fortalecimento de movimentos populares para a condução política de processos de transformação social'(BRANDÃO,1995)
} 
modelagem de acompanhamento. Esse referencial também aparece atualmente bastante difundido em projetos de gestão participativa de bacias hidrográficas ${ }^{8}$ na Europa.

Durante muito tempo, o campo da gestão dos recursos naturais vem trabalhando com os princípios da ótima alocação de recursos e de ótimas estratégias de controle. Tais estratégias supõem critérios bem objetivos e um profundo conhecimento sobre o sistema, o que levou ao desenvolvimento de diversos métodos e instrumentos de suporte à tomada de decisão, genericamente chamados de sistemas de suporte à decisão (DASGUPTA, 2003). Parte-se da crença que estes vários sistemas de suporte apresentam potenciais para auxiliar os gestores a explorar os efeitos de ações propostas e até mesmo comparar e avaliar estratégias de ação de acordo com critérios pré-definidos. No entanto, o processo de tomada de decisão nem sempre se baseia exclusivamente em critérios "racionais", o que torna a eficiência de tais instrumentos bastante questionável. A gestão dos recursos hídricos envolve uma série de fatores econômicos, sociais, ambientais e, portanto, deve lidar com muitas incertezas inerentes ao processo (PAHL-WOSTL, 2002).

Além disso, a gestão participativa envolve decisões coletivas, negociadas e não apenas decisões individuais, potanto é preciso desenvolver um aprendizado por todas as partes envolvidas no processo, num processo de acordos, concertações e negociações. Nestas instâncias a aprendizagem social no processo coletivo, de grupo apresenta-se como uma possibilidade.

Neste sentido, Pahl-Wostl argumenta sobre a necessidade de incorporar a concepção de "aprendizagem social" buscando ir além do simples processo racional de tomada de decisão, um conceito que pretende integrar os seguintes fatores: uma reflexão crítica; o desenvolvimento de um processo participativo, múltiplo e democrático; a construção de uma percepção partilhada do problema em relação ao grupo de atores sociais envolvidos; o reconhecimento das interdependências e interações dos atores (PAHL-WOSTL, 2002).

\footnotetext{
${ }^{8}$ Como exemplo utilizamos o projeto HarmoniCOP - ('Harmonising Collaborative Planning"), um projeto de cooperação européia que envolve diversas instituições de pesquisa para a gestão de bacias hidrográficas em diversas regiões da Europa. Tal projeto pretende analisar a relevância de ferramentas de informação e comunicação (IC-tools), das quais o jogo de papéis faz parte, no desenvolvimento da "aprendizagem social"para a gestão participativa da água. (www.harmonicop.info)
} 
A abordagem da "aprendizagem social" (Social Learning) parte da premissa de que os conflitos sócio-ambientais requerem não só o conhecimento técnico para o entendimento dos conteúdos envolvidos, mas também a incorporação da dimensão humana no processo de gestão, envolvendo os aspectos psicológicos e as relações sociais inerentes ao contexto. Esta aprendizagem envolve as interações dos diversos atores, a busca de uma visão compartilhada do problema e o processo de negociação dos diversos interesses, muitas vezes conflitantes no processo de gestão (PAHL-WOSTL, 2002).

As origens do conceito de "aprendizagem social" remetem à Psicologia, tendo sido o termo proposto por Albert Bandura (1971) para referir-se ao processo de desenvolvimento cognitivo (aprendizagem) dos indivíduos no contexto social. Tal conceito é também utilizado na área da Educação, mais recentemente, nos processos de educação de adultos e educação para a cidadania. "A cidadania pode ser aprendida como uma aptidão ou habilidade, não pelo currículo formal, mas por experiências práticas de participação" (BENN, 2000 apud CRAPS, 2003 ).

A abordagem utilizada nos processos de gestão de água está mais relacionada às reflexões dos últimos anos referentes à colaboração multi-parte, às parcerias públicoprivadas, e à governança colaborativa. Os conceitos de aprendizado organizacional e aprendizagem social receberam diversas críticas pelo fato de ser uma abordagem demasiado instrumentalista e orientada ao desenvolvimento de técnicas de gestão. Entretanto, se for considerada conjuntamente à questão da construção social do conhecimento e da realidade, de acordo com autores como Maturana \& Varela (1987), as reflexões sobre a aprendizagem social são aprofundadas ao pensar as inter-relações entre ciência, sociedade e ambiente (CRAPS, 2003).

Entretanto aqui cabe uma ressalva no que se refere às teorias de Maturana e Varela (2001) sobre a idéia de árvore do conhecimento que estes autores apresentam. Tal concepção não se reduz apenas à construção social do conhecimento, mas despertam para "a aceitação do outro junto a nós", pautada na questão da convivência e do campo afetivo, as quais, segundo os autores, estão na base de toda a socialização e, conseqüentemente do processo de conhecimento. Esse processo envolveria ainda o 
comprometimento e a responsabilidade sobre os atos, aspectos que, aparentemente, não estão contemplados na abordagem da "aprendizagem social" (MATURANA; VARELA, 2001).

Atualmente o conceito perpassa diversas correntes das Ciências Sociais e pretende contribuir para explicitar os objetivos de todos os atores envolvidos no processo; alcançar melhores soluções (mais democráticas) para as questões sócio-ambientais e melhores maneiras de gerenciar os conflitos (PAHL-WOSTL, 2002). O conhecimento técnicocientífico é reconhecido como uma das partes do processo e não como a única forma de conhecimento, este deve contribuir no processo coletivo de discussão, assim como os outros conhecimentos, igualmente relevantes no entendimento da situação.

Uma outra crítica que a abordagem recebe vem da teoria crítica, desenvolvida por Habermas (1984) no campo das ciências sociais que questiona a abordagem da "aprendizagem social" como uma "pseudo -participação", assim como outras iniciativas que abordam os aspectos técnicos da participação sem questionar a questão da distribuição de poder que uma efetiva participação envolve (CRAPS, 2003).

Neste sentido, é importante destacar os desafios da participação em relação ao conceito da aprendizagem social. Como a abordagem participativa não está introjetada por todos na sociedade atual e ainda assistimos grandes desigualdades presentes no que se refere aos canais democráticos, a abordagem do conceito de "apr endizagem social" pode trazer uma visão simplificada da situação. Neste caso, no que concerne ao estudo de metodologias participativas, a participação não pode ser encarada como algo único, mas um conceito complexo que compreende diversos níveis de participação. Alguns destes desafios são destacados no texto abaixo.

\subsubsection{Os desafios da participação}

No contexto dos conflitos socioambientais a participação efetiva da sociedade civil, principalmente por seus representantes de base ainda é um ideal a ser perseguido. Apesar do Sistema de Gerenciamento dos Recursos Hídricos apresentar como pressuposto a 
participação da sociedade civil, a efetiva participação dos movimentos populares no sistema ainda é bastante limitada. (MARTINS, 2001).

A participação popular é, neste sentido, um ideal que precisa ser uma busca constante, pois nunca aparece como uma dádiva, mesmo que instituída nos fóruns apropriados. A participação é um processo que precisa ser conquistado diariamente (DEMO, 2001).

"As transformações político -institucionais, e a ampliação de canais de representatividade dos setores organizados para atuarem junto aos órgãos públicos; enquanto conquista dos movimentos organizados da sociedade civil, mostram a potencialidade de construção de sujeitos sociais identificados por objetivos comuns na transformação da gestão da coisa pública, associado à construção de uma nova institucionalidade. Quando se fala de "participação dos cidadãos"deve se enfatizar que se trata de uma forma de intervenção na vida pública com uma motivação social concreta que se exerce de forma direta, baseada num certo nível de institucionalização das relações Estado/ Sociedade.” (JACOBI, 1996)

Aqui vale destacar o tema que abordamos nesta pesquisa, a necessidade de haver um processo de educação para a participação. Pedro Demo coloca a educação como instrumento de formação à cidadania, participação política e de socialização dos cidadãos que permitirá a apropriação desses espaços e canais de participação institucionalizados (DEMO, 2001).

Neste sentido recorre-se aos princípios da participação cidadã evidenciados por Arnstein em sua "escada da participação cidadã". A autora desenvolve uma escala de níveis de participação para explicitar que nem todas as ações que se dizem participativas o são realmente, analisando ações de planejamento do governo norte-americano (ARNSTEIN, 1969).

Segundo o raciocínio de Arnstein, participação cidadã é um sinônimo para "poder cidadão", ou seja, a participação envolve distribuição de poder que permite a inclusão do s cidadãos mais excluídos no processo de tomada de decisão. Nas palavras da autora:

“..a participação constitui o meio pelo qual os sem-nada podem promover reformas sociais significativas que lhes permitam compartilhar 
dos benefícios da sociedade envolvente(...) participação sem redistribuição de poder é um processo vazio e frustrante para os grupos desprovidos de poder" (ARNSTEIN, 1969)

De acordo com estes princípios, Arnstein desenvolveu uma tipologia de oito níveis o que chamou de "degraus da participa ção cidadã", desde a não-participação caracterizada por ações de "manipulação" e de "terapia" até os níveis de poder cidadão: "parceria", “delegação de poder"e "controle cidadão”, conforme ilustra figura abaixo.

Figura 6 - Oito degraus da participação cidadã

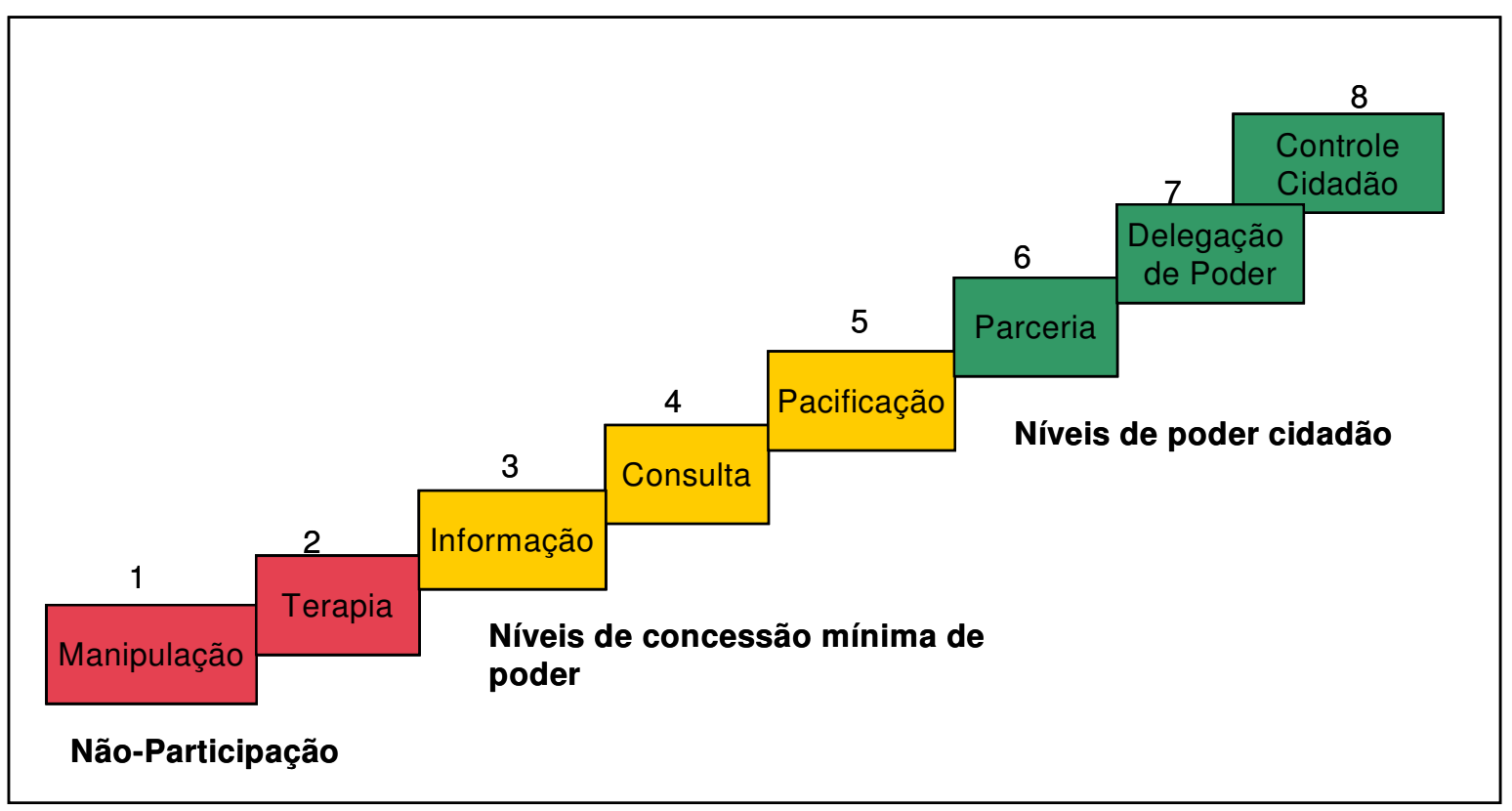

Fonte: ARNSTEIN.S, 1969.

Aqui a questão que se coloca é: Como garantir que os atores locais envolvidos na problemática realmente participem de forma cidadã do processo de gestão ambiental, sendo este um sistema de disputa, que envolve relações de poder e conflitos de interesses?

E na realidade brasileira, num contexto em que existem desníveis de instrução, como permitir a participação efetiva de todos, além da simples presença em reuniões?

Tais questões são fundamentais ao se analisarem metodologias participativas, categoria na qual os jogos de papéis, tanto sob o enfoque da modelagem de acompanhamento, 
quanto da aprendizagem social, estão inseridos (BARRETEAU, 2003; PAHL-WOSTL; HARE, 2004; BROSE, 2001).

\subsubsection{A Educação Ambiental e a questão da complexidade}

Os desafios de uma participação efetiva dos vários atores e segmentos da sociedade civil estão também bastante relacionados com a complexidade dos conflitos abordados na área ambiental. A reflexão sobre uma educação para a participação leva-nos à discussão da Educação Ambiental de uma forma mais ampla, entendida como uma educação que contribua na formação de cidadãos participativos para enfrentar os conflitos socioambientais.

Para tanto, são necessárias ferramentas didáticas que explicitem a complexidade dos problemas devido aos vários interesses envolvidos e às múltiplas configurações que podem assumir. A complexidade apresenta-se em duas vertentes: de um lado a do contexto permeado por múltiplos interesses e uma interdependência de fatores, e de outro, a necessidade de metodologias complexas que consigam discutir a problemática da situação de uma forma ancorada na realidade. Aqui vale destacar uma breve reflexão sobre a questão da complexidade, uma vez que os jogos de papéis aparecem como metodologias de formação mais elaboradas que permitem visualizar grande parte das interações envolvidas nos conflitos socioambientais e que apresentam, portanto um nível maior de complexidade do que as tradicionais cartilhas ou manuais didáticos de formação.

Da mesma forma, em se tratando de uma proposta de Educação Ambiental em sua vertente crítica e transformadora ${ }^{9}$, um dos aspectos essenciais é a abordagem da complexidade no tratamento das questões ambientais. Portanto, são necessárias algumas considerações sobre o conceito de complexidade que também servirão de suporte na análise dos jogos de papéis com o enfoque na modelagem de acompanhamento, pelo fato de que estes são considerados metodologias complexas.

\footnotetext{
${ }^{9}$ A vertente crítica e transformadora da Educação Ambiental pressupõe a incorporação dos aspectos sociais, políticos e ambientais e a perspectiva problematizadora de Educação. Em oposição à vertente conservadora que apenas trata dos fatores ecológicos desconectados das questões sociais (LIMA, 2002)
} 
A abordagem complexa das questões ambientais nas práticas educativas vai sinalizar o caráter integrador esperado de uma EA crítica. O desafio reside na EA ser uma forma de explicitar os conflitos de interesses presentes na sociedade incorporando sua dimensão complexa (LAYRARGUES, 2003 apud LIMA, 2005).

O conceito de complexidade, por ser bastante utilizado, freqüentemente situa-se no senso comum, na falta de um outro adjetivo para descrever uma situação utiliza-se o termo "complexo". Jollivet e Pavé (1997) destacam a necessidade de uma definição pertinente do termo nos estudos ambientais que utilizam tal concepção de complexidade. De acordo com os autores, existem dois tipos de complexidade: i) "áleatória", na qual é complexo "tudo aquilo cuja descrição é longa", como um sistema de nume rosos componentes e ii) "lógica", a qual compõe -se por uma "ássociação múltipla de símbolos elementares”, do tipo dos objetos fractais, num padrão linear ou não de interações entre os componentes do sistema (JOLLIVET; PAVÉ, 1997). No entanto estas definições não parecem suficientes.

Considera-se então o conceito de complexidade evidenciado por Morin, no qual complexus é aquilo que foi "tecido junto", o que está intrinsecamente ligado, não apenas como uma somatória de fatores. A esta concepção soma-se o princípio da incerteza do conhecimento. Morin afirma que para entender o desafio da complexidade é preciso superar os princípios que durante muitos anos estiveram como base do pensamento cientifico e, conseqüentemente educativo. O princípio da ordem, a idéia do funcionamento do mundo como o de uma "máquina perfeita" e o princípio da separação, expressão máxima do pensamento cartesiano. A separação das matérias como forma de organizar o conhecimento, a separação do objeto e do sujeito, a organização das disciplinas que impedem a prática interdisciplinar. Assim como o princípio da redução, o qual diz que a partir das partes é possível conhecer o todo e o princípio da lógica clássica: dedutivo-indutivo-identitária, que levava ao abandono do raciocínio em função de qualquer contradição que caracterizava o erro. (MORIN, 2004):

$\mathrm{O}$ autor demonstra que muitos destes princípios foram abalados ao longo do século XX e que em meados do século XXI as pesquisas cientificas, principalmente no campo da física contribuíram para o surgimento das revoluções científicas, pautadas no princípio da 
incerteza. A idéia de complexidade implica em como conceber a relação entre a ordem, desordem e organização. O princípio da redução dá lugar ao da complementaridade (MORIN, 2004).

Segundo o autor, a complexidade lida com as articulações entre os aspectos de uma realidade, ou no caso, de uma questão ambiental, "não se trata de dar todas as informações sobre um fenômeno estudado, mas de respeitar as suas diversas dimensões, aspira à multidimensionalidade" (MORIN, 1989).

"A complexidade faz apelo à estratégia. A estratégia é a arte de utilizar as informações que surgem durante a ação, integrá-las, formular subitamente esquemas de ação e ser capaz de reunir o Maximo de certezas para defrontar o incerto"

(MORIN, 1989)

Em relação ao tema da pesquisa, a questão que se coloca para nos fazer pensar, mas que talvez não tenhamos pistas suficientes para respondê-la é: Qual o nível de complexidade que os jogos de papéis, com o enfoque da modelagem de acompanhamento, apresentam? Uma complexidade no sentido de Morin (1989), do que é tecido em conjunto a partir de diversos e diferentes "fios" ou uma complexidade mais próxima à soma ou reunião de um conjunto de múltiplas variáveis, organizadas num sistema comum?

\subsection{A DIVERSIDADE DO CONCEITO JOGO E SUA CLASSIFICAÇÃO}

Partindo das diversas definições de jogos de papéis, verifica-se também uma ampla heterogeneidade sobre a definição do conceito jogo em geral. Isto se dá em parte devido à diversidade de tipos de jogos existentes, em parte pelo sentido conotativo e metafórico que a palavra assume na sociedade. As referências ao jogo em geral apresentam relevância para a pesquisa na medida que se pretende discutir a função do lúdico nas práticas educativas. O elemento lúdico presente nos jogos aparece como um fator essencial a ser considerado na análise de tais metodologias.

Caillois, uma das referências clássicas no assunto, discute a dificuldade de definição do conceito, apresentando o jogo como uma atividade com as seguintes características: 1) liberdade - os jogadores não são obrigados a jogar; 2) isolamento - ocorre dentro de limites pré-estabelecidos de tempo e espaço; 3) incerteza - o desenrolar do jogo não é 
pré-determinado, depende do processo realizado pelos jogadores; 4) improdutividade -o jogo tem um fim em si mesmo; 5) a presença de regras - há um conjunto de regras às quais os jogadores devem seguir para jogar; 6) fictícia - há uma realidade "virtual" no processo (CAILLOIS, 1958).

O referido autor propõe a seguinte classificação para os jogos: Agôn, Alea, Mimicry e Ilinx, de acordo com os critérios de competição, sorte ou acaso, simulacro e vertigem, respectivamente. Na categoria Agôn, Caillois situa os jogos que pressupõem a competição, em que há um adversário a ser vencido, são estes a maioria dos jogos esportivos, o xadrez, o jogo de damas, o bilhar. Jogos da categoria Alea, ao contrário dos primeiros, são aqueles em que há um domínio da sorte, tais como jogos de roleta e de loteria, nos quais, de forma aleatória, a decisão não depende tanto do jogador, mas do acaso. Já na terceira categoria - Mimicry - situam-se os jogos que propõem uma ilusão, um universo fictício temporariamente. Também são aqueles jogos em que os jogadores devem assumir um papel diferente do que têm na realidade, representando um personagem. Nesta categoria são encontradas as características mais próximas dos atuais jogos de papéis que serão analisados de forma pormenorizada neste estudo. Finalmente, na categoria Ilinx estão os jogos que provocam vertigem, física e psicológica, do tipo de acrobacias circenses e esportes como alpinismo (CAILLOIS, 1958).

Macedo (1997), de acordo com Piaget, classifica os jogos em quatro categorias: (1) jogos de exercício que correspondem aos primeiros jogos da infância, pautados na repetição; (2) jogos simbólicos, nos quais a criança age como se fosse outra pessoa, experimentando novos papéis e fantasias; (3) jogos de regras, em que há um sistema de regras predefinido e um caráter coletivo, pois a ação de um jogador é dada em função do outro e (4) jogos de construção, nos quais a ênfase do jogo está no processo, nas relações estabelecidas durante o jogo. Nesta perspectiva, os jogos de papéis são caracterizados por jogos de construção, cujo foco está na vivência e no processo. A construção dos personagensjogadores e da situação-problema correspondem ao processo vivenciado neste tipo de jogos (MACEDO,1997). 


\subsubsection{O jogo e a cultura}

"o jogo é uma atividade ou ocupação voluntária, exercida dentro de certos e determinados limites de tempo e de espaço, segundo regras livremente consentidas, mas absolutamente obrigatórias, dotado de um fim em si mesmo, acompanhado de um sentimento de tensão e de alegria e de uma consciência de ser diferente da vida quotidiana"

(HUIZINGA, 2001)

$\mathrm{O}$ aspecto cultural do jogo, na definição de Huizinga apresenta importância no presente estudo por conceber o jogo como prática cultural e atividade voluntária, tal definição é, de certa forma, contrária à concepção do "jogo educativo", que se constitui como o tema da pesquisa. Caillois, mencionado anteriormente também atribui ao jogo, o caráter de improdutividade, por ser este uma atividade com fim em si mesma (CAILLOIS, 1958). Tais características relacionam-se ao jogo livre no qual não há uma clara intenção pedagógica. No jogo pedagógico ou quando este é utilizado como metodologia de suporte a práticas educativas, estas características geram controvérsias, aqui vale uma reflexão sobre quão lúdico consegue ser um jogo com objetivos pedagógicos, da mesma forma que o caráter improdutivo e livre apresentam um certo tipo de restrição neste sentido.

Em sua obra de referência "Homo ludens", Huizinga entende o jogo como algo anterior a cultura, uma vez que já é possível verificar nos animais atividades semelhantes ao que denominamos jogo. $\mathrm{O}$ autor enfatiza ainda, que as ciências sociais e a antropologia não têm considerado a tamanha importância do fator lúdico presente na civilização. $\mathrm{O}$ fator lúdico, segundo Huizinga, está tão presente nas culturas primitivas, nas sociedades tradicionais e até na modernidade que a espécie humana deveria juntamente à definição de Homo sapiens, receber a denominação "Homo ludens" (HUIZINGA, 2001).

Na definição de Huizinga são destacadas características pertinentes ao jogo tais como a diferenciação da vida real ou cotidiana, o seu caráter desinteressado ou voluntário e a presença de regras. Um outro fator inerente ao jogo é a capacidade de "absorver" os jogadores, o que traz a idéia do "feitiço" do jogo devido aos sentimentos de tensão e alegria proporcionados por tal atividade (HUIZINGA, 2001). 
A idéia do mundo virtual e fantasioso, proposto pelo cenário do jogo, permite aos jogadores mobilizarem registros tanto do lúdico e simbólico, mas também registros cotidianos que os sujeitos trazem de suas vivências e histórias de vida. Estas observações foram demonstradas por Daré em sua tese sobre os comportamentos dos jogadores num jogo de papéis sob o enfoque da modelagem de acompanhamento desenvolvido no Senegal (DARÉ, 2005).

Quanto ao caráter lúdico do jogo, oposto à seriedade, alguns autores ressaltam, no entanto, que "certas formas de jogo podem ser extraordinariamente sérias", o que pode ser comprovado ao observar a seriedade de uma criança brincando ou de dois adultos numa partida de xadrez, por exemplo (MACEDO, 1997; HUIZINGA, 2001).

\subsubsection{O jogo e a educação}

Dentre a multiplicidade e a diversidade de conceitos que a palavra "jogo" pode assumir, destacam-se os elementos do jogo com potenciais educativos, nos diversos âmbitos de ensino e as práticas verificadas atualmente em relação aos jogos de papéis.

O potencial lúdico, a presença de regras e a possibilidade de cooperação são alguns dos elementos que possibilitaram a inserção dos jogos nas práticas educativas. A idéia de aprender de forma lúdica, a partir da vivência ganhou bastante destaque com o construtivismo e formas de educação mais cooperativas (MACEDO, 1997).

A utilização de jogos na educação é verificada há muito tempo, desde às experiências de Piaget, sobre o desenvolvimento da criança (PIAGET, 1930). O conceito de jogo educativo infantil foi desenvolvido por Froebel nos jardins de infância da França que tiveram bastante influência nos jardins de infância no Brasil no século passado (KISHIMOTO,1993).

Segundo Claparède, todos os jogos são, em sua essência, educativos. Dewey acrescenta ainda que o jogo assume papel fundamental no desenvolvimento da criança. $O$ autor defende a prática de jogos teatrais ou dramatizações como potencial para o aprendizado 
das diversas disciplinas escolares, numa forma ativa de educação que busca os interesses do aluno (KISHIMOTO, 1993).

Piaget utilizava os jogos de regras para compreender o nível de desenvolvimento das crianças em relação à compreensão das regras em geral. As crianças menores entendem a presença de regras como algo externo ao jogo, imutável, o que o autor denominou de heteronomia; já as crianças maiores conseguem perceber a possibilidade de construir novas regras, indicando o conceito de autonomia (PIAGET, 1930).

Piaget via na situação do jogo - uma atividade estabelecida a partir de determinadas regras, um potencial de formação da autonomia no processo de educação. Na medida que os sujeitos participantes do jogo têm a liberdade de mudar as regras de uma situação, definindo-as conjuntamente, isso pode desenvolver nos sujeitos um senso de coletividade e autonomia (PIAGET, 1930).

Macedo, ancorado nos princípios de Piaget, ressalta o caráter simbólico do jogo como um fator essencial ao desenvolvimento da criança. Segundo o autor, o brincar é uma atividade fundamental e o jogo é uma "brincadeira organizada, com regras e objetivos pré-definidos". O brincar é uma necessidade da criança, o jogo, uma de suas possibilidades à medida que nos tornamos adultos (MACEDO, 2005).

Encontra-se uma vasta referência da utilização de jogos na educação infantil, tanto nos estudos ligados ao desenvolvimento da criança na Psicologia da Educação, quanto nas práticas relacionadas aos problemas de aprendizagem na área da Psicopedagogia (KISHIMOTO, 1993; MACEDO, 1997).

Com a ampla difusão e o grande apelo comercial dos famosos RPGs (role-playing games ou jogos de papéis) entre o público jovem e adolescente, tais metodologias adentraram no contexto escolar apresentando-se simultaneamente como instrumento lúdico e educativo. 
No processo de "escolarização do $\mathrm{RPG}{ }^{10}$ ", os conteúdos das várias disciplinas são estudados em sessões e aventuras de RPG, principalmente na área de história e literatura.

A maioria das teses e dissertações sobre o RPG encontra-se na área de Letras, principalmente na análise dos jogos de papéis como narrativa, ou "arte de contar histórias"(PAVÃO, 2000; MOTA, 1997).

Se por um lado a autoria de novas aventuras de RPG possui amplo potencial de estímulo à criação e criatividade, tanto dos alunos quanto dos professores; o que se verifica é a entrada destas práticas na escola trazidas por "especialistas" de forma pronta, mercadológica e simplificada, desconsiderando a prática cotidiana e a autonomia do professor. Neste contexto, pouco se valoriza o saber pedagógico e a prática cotidiana escolar do professor, mas apenas o conhecimento do especialista que tenta inserir o RPG na escola. Desta forma a autoria do professor é limitada, trata-se mais de uma reprodução (FAIRCHILD, 2004).

Outro ponto importante analisado por Fairchild é a necessária distinção entre informação e conhecimento. $\mathrm{O}$ autor mostra que o jogo muitas vezes possibilita a retenção de uma série de informações relativas ao conteúdo do jogo, o que nem sempre corresponde ao salto qualitativo de uma aprendizagem significativa do conhecimento em questão. A conclusão a que chega o pesquisador remete à necessidade de valorização da autonomia do professor e do aluno, enxergando no RPG uma possibilidade de autoria conjunta e não apenas a sua inserção no ambiente escolar de forma externa e desintegrada ao processo (FAIRCHILD, 2004).

Ainda em relação à utilização de jogos no que concerne à Educação de adultos, não podemos deixar de citar os jogos de empresas, muito utilizados em cursos de Administração de Empresas e Negociação e os jogos de simulação aplicados nos cursos de Sociologia como forma de estimular o pensamento crítico, a capacidade de tomar decisões e resolução de problemas (DORN, 1989).

\footnotetext{
${ }^{10}$ Fairchild, T. (2004) 'O discurso da escolarização do RPG” dissertação de mestrado apresentada na Faculdade de Educação da USP.
} 
No Brasil há uma tradição forte ligada ao Psicodrama ou Role-Playing que se origina na Psicologia e depois ganha espaço na área educacional, juntamente com as técnicas e conceito do Teatro do Oprimido com Augusto Boal. Na década de 60 estas técnicas foram bastante utilizadas na formação de líderes dos movimentos sindicais como suporte em negociação.

Na Psicologia, Moreno desenvolve um amplo estudo sobre o Role Playing e a técnica da inversão de papéis, denominada Psicodrama. As origens deste jogo de papéis situam-se no teatro espontâneo, que depois originou o teatro terapêutico e, consequentemente suas subdividões: Psicodrama, Psicoterapia de grupo e Sociodrama (MORENO, 1923 apud WECHSLER, 1999).

\subsubsection{Origens e definições dos jogos de papéis}

O conceito de jogos de papéis mais difundido nos meios de comunicação refere-se à tradução de "role-playing game" (RPG) ${ }^{11}$, termo inglês utilizado para denominar um conjunto de jogos de interpretação que misturam jogo e teatro na vivência de uma situação ou história a partir dos personagens-jogadores. Segundo Mota, autora da primeira tese de doutorado sobre o tema no Brasil, o RPG é um jogo de produzir ficção, no qual uma aventura é proposta pelo narrador - o mestre - e interpretada por um grupo de jogadores. A ação do jogo pode se desenrolar em vários "mundos": de f antasia medieval, terror ou futurista (MOTA, 1997).

Fairchild demonstra, a partir do resgate de trabalhos acadêmicos brasileiros que abordam a temática, que embora haja uma certa controvérsia em relação às origens dos RPGs, estas remetem aos jogos de guerra (wargames) e/ou jogos de estratégia, concretizando-se nos EUA no inicio dos anos 70 (FAIRCHILD, 2004).

\footnotetext{
11 A expressão RPG vem do inglês "role-playing games" que pode ser traduzida para "jogos de interpretação ou jogos de papéis". Sua origem encontra-se nos EUA, no ano de 1974 com a criação do primeiro RPG intitulado "Dungeons \& Dragons", este é um dos RPGs mais jogados no mundo e simula aventuras na época medieval. No Brasil, este tipo de jogo apareceu em 1985 através da série "Aventuras Fantásticas”(Marcatto, 1996, Mota, 1997, Pavão, 2000, Fairchild, 2004).
} 
Alguns estudos indicam que os jogos de papéis estão igualmente inseridos num contexto mais amplo dos jogos urbanos de simulação (Urban Gaming Simulation - UGS $)^{12}$. Tais jogos surgiram em universidades norte-americanas nos anos 60 ancorados na tendência dos jogos de simulação para a área militar e a administração de empresas. Nas décadas de 60 e 70 houve uma difusão dos UGS em relação ao treinamento para gestores ligados ao planejamento urbano, estas ferramentas pareciam ser úteis na elaboração de análises, projeções e políticas públicas. Posteriormente, uma crise tornou esse tipo de jogos obsoletos devido a fatores como a complexidade de modelos de larga-escala e o alto custo. A dificuldade de compreensão de modelos de larga-escala ou modelos "caixa preta" (black-box models) e a abordagem de cima para baixo na utilização destas ferramentas foram também motivos de críticas (LEE, 1994 apud CECCHINI, 2001).

Em relação às perspectivas atuais e futuras dos jogos urbanos de simulação (UGS), Cecchini e Rizzi (2001) apontam a necessidade de uma discussão epistemológica, metodológica e política ancorada no paradigma da complexidade. Para entender a dinâmica urbana, os autores argumentam que é preciso tanto olhar a cidade do "topo de uma montanha" para entender o seu contexto, quanto andar nas ruas e interagir com os habitantes, descobrindo as razões das ações de cada segmento que se pretende compreender (CECCHINI; RIZZI, 2001).

Para o desenvolvimento desta "hova geração" de UGS, a primeira condição a ser considerada é que o modelo ou o jogo seja útil para os usuários e desenvolvido em cooperação com os mesmos. Que seja facilmente adaptável e de fácil utilização, que provoquem uma consciência e um "despertar" para os problemas, através da simulação de cenários alternativos e do desenvolvimento de estratégias efetivas de negociação e comunicação. Finalmente uma condição fundamental é que sejam desenvolvidos com os métodos e técnicas disponíveis e acessíveis, não necessariamente as mais modernas e

\footnotetext{
${ }^{12}$ Os jogos de simulação urbana (UGS) abordavam questões de planejamento e modelos de uso e ocupação do solo. Estas ferramentas combinavam modelos com jogos mais acessíveis aos atores sociais, nos quais era possível simular os impactos das decisões das pessoas, de acordo com seus papéis. Nesta época as cidades americanas enfrentavam diversas crises sociais relacionadas às questões de racismo, violência e decadência urbana (Cecchini e Rizzi, 2001).
} 
sofisticadas, como afirmam os críticos: “ às vezes um simples jogo feito com papel e caneta pode ser útil e suficiente" (CECCHINI; RIZZI, 2001).

Os jogos de papéis sob o enfoque da modelagem de acompanhamento constituem uma das metodologias de trabalho utilizadas para tornar os modelos mais acessíveis ao público em geral, principalmente os atores locais, desvendando os conteúdos da "caixa preta" que caracterizam os modelos tradicionais (BARRETEAU, BOUSQUET, ATTONAY, 2001).

O jogo de papéis aparece neste contexto como uma possibilidade de aprendizagem para a negociação de conflitos, na medida em que os papéis geralmente se referem a pessoas envolvidas nos conflitos reais, representam indivíduos ou grupos de pessoas com interesses distintos numa mesma situação a ser resolvida. A dinâmica do jogo desenrolase através de interações entre os jogadores variando da competição à cooperação, há um conjunto de regras e cenários que podem ser modificados de acordo com as decisões tomadas pelos jogadores, neste sentido são jogos de simulação (DORN, 1989).

Segundo Daré, o jogo é uma representação esquemática da realidade que pode revelar as relações sociais entre os jogadores. O referido autor utiliza a definição de Mucchielli (1983) na qual o jogo de papéis é uma construção de uma situação problemática, situada entre o jogo e o teatro, em que as pessoas desempenham papéis pré-definidos. Neste sentido, o jogo de papéis (RPG) é composto por três elementos: (1) o jogo em si, composto por um sistema de regras e o ambiente no qual se desenrola a ação; (2) o facilitador ou "mestre do jogo", aquele que organiza a sessão, conhece todas as regras e orienta os jogadores e (3) os jogadores, participantes que desempenham papéis durante a realização do jogo. (MUCCHIELLI, 1983 apud DARÉ, 2003):

Nas diretrizes do projeto "HarmoniCop - Aprendizagem Social no gerenciamento de bacias hidrográficas" (citado anteriormente) os jogos de papéis (RPG) são apresentados na categoria das ferramentas de informação e comunicação ${ }^{13}$, a qual compreende desde ferramentas informatizadas como Sistema de Informação Geográfica (SIG) até

\footnotetext{
${ }^{13}$ Tradução de 'IC -tools", termo utilizado no projeto HarmoniCop para se referir às ferramentas de Informação e Comunicação, categoria na qual encontram-se os jogos de papéis (CRAPS, 2003)
} 
metodologias não informatizadas como mapas, maquetes, jogos de tabuleiro (CRAPS, 2003).

A pertinência da utilização de jogos de papéis (RPG), de acordo com o projeto acima citado, reside em aspectos como identificação de problemas, busca e escolha de soluções, análise de políticas públicas e na validação de modelos (CRAPS, 2003).

De acordo com este referencial teórico, a participação no desenvolvimento da ferramenta é também de fundamental importância à medida que pode melhorar o processo de comunicação entre os diversos atores envolvidos, obter representações mais próximas da realidade, possibilitar um reconhecimento mútuo e uma apropriação da ferramenta por parte dos atores e, finalmente, promover um contexto de comunicação bi-direcional (CRAPS, 2003).

Os jogos de papéis apresentam uma possibilidade importante no contexto pedagógico que é a de se colocar no lugar do outro a partir da vivência dos papéis/personagens que compõem a situação-problema. Isso, que denominamos "empatia", amplia a visão sobre determinada questão, na medida que traz novos olhares a partir dos variados interesses sobre um mesmo recurso ambiental. O conceito de empatia é também usado bastante na literatura referente à negociação, segundo um dos modelos de uma boa negociação, deve haver um equilíbrio entre o nível de empatia e assertividade com o objetivo de chegar a opções de ganhos mútuos (FISHER; URY, 1994).

A composição dos jogos de papéis é basicamente a seguinte: (1) uma situação-problema, (2) um conjunto de jogadores/ personagens que representam a situação e tomam decisões de acordo com as regras do jogo e (3) o mediador ou mestre do jogo, papel essencial que explica as regras da situação, contribui para a discussão sem tomar partido e finalmente conduz a avaliação final e a análise do jogo, parte imprescindível da atividade.

Macedo utiliza o conceito de situação-problema como um recurso importante ao aprendizado e à avaliação, na medida em que nos desafiam a solucionar possíveis problemas do cotidiano. Para o educador, "Situações-problema se caracterizam por 
recortes de um domínio complexo, cuja realização implica mobilizar recursos, tomar decisões" (MACEDO, 2000).

As situações-problema são estratégias interessantes para que os educandos percebam a complexidade dos problemas ambientais e se coloquem no lugar dos tomadores de decisão, assumindo assim a responsabilidade sobre as questões ambientais. Além disso, a vivência de uma situação problemática e o desafio à resolução conjunta da questão pode provocar uma disposição à mudança e uma mobilização para a participação.

\subsubsection{A importância do “debriefing” ou análise final do jogo}

A fase de análise final ou "debriefing" do jogo é uma das partes fundamentais da sessão de um jogo de papéis ou um jogo de simulação, uma vez que é o que confere sentido à prática do jogo, explicitando as estratégias de cada um dos jogadores e verificando as semelhanças e diferenças do jogo em relação ao conflito real.

A análise final de um jogo de papéis é essencial porque esse tipo de atividade muitas vezes mobiliza as pessoas e traz à tona diversos sentimentos, é fundamental reservar um tempo para que os participantes possam expressar o que sentiram durante o jogo. Isso também pode ajudar aos participantes enxergarem a situação com um certo distanciamento, o que pode trazer novas soluções para os problemas (PETERS, 2004).

Tal avaliação ou análise do jogo é o momento mais importante, pois é ela que dará sentido ao que foi vivenciado durante o jogo de papéis e tornará possível fazer as ligações e relações com a realidade que se pretende problematizar. A análise deve durar 1/3 do tempo do jogo, assim se tivermos um período de 3 horas para o jogo, uma hora deve ser reservada para a avaliação. O mediador é o responsável por conduzir a avaliação do jogo, que deve abordar as principais questões suscitadas pela atividade (DORN, 1989).

William Daré em sua pesquisa, na qual realiza uma analise sociológica do jogo de papéis utiliza as discussões coletivas da análise final do jogo para coletar dados. A importância deste processo situa-se no fato de que é o momento em que os participantes podem 
expressar-se livremente sobre as impressões do jogo, descrevendo as dificuldades e os desafios vivenciados durante o jogo (DARÉ, 2005).

A análise final do jogo deve ser orientada e desenvolve-se em três etapas, segundo as instruções de Steinwachs no artigo intitulado- How to facilitate a Debriefing (STEINWACHS, 1992):

1) Fase da descrição - os participantes explicam suas estratégias durante o jogo e as decisões tomadas, relatam as dificuldades e os desafios inerentes a cada um dos papéis. Nesta fase são esclarecidos os objetivos e as regras do jogo;

2) Fase de análise - nesta fase são analisados os resultados da sessão de jogo, através de gráficos, índices de poluição e outros indicadores que o sistema permite explicitar através da mudança de cenários durante o jogo. Os resultados do jogo são discutidos e os vários cenários que se construíram ao longo do jogo, são então analisados tanto nos aspectos da problemática do contexto, quanto das inetrações e relações sociais estabelecidas ao longo do jogo.

3) Fase de analogia - o que o jogo apresenta em comum com a realidade em questão? Quais as formas de negociação de conflitos verificadas tanto no jogo, quanto no conflito real? O que os participantes aprenderam sobre a negociação de conflitos sócio-ambientais, o que aprenderam sobre a problemática dos mananciais ou sobre outro assunto específico ao jogo? A partir dessas questões os participantes vão compreendendo melhor o que foi verificado durante a sessão de jogo e como podem aplicar na realidade os conceitos aprendidos e vivenciados.

\subsection{AS CONCEPÇÕES DE EdUCAÇÃo E SEUS DIÁlOGOS COM OS JOGOS DE PAPÉIS: POSSIBILIDADES DA EDUCAÇÃO AMBIENTAL NESTE CONTEXTO}

"A educação que se impõe aos que verdadeiramente se comprometem com a libertação não pode fundar-se numa compreensão dos homens como seres vazios a quem o mundo "éncha" de conteúdos; não pode basear-se numa consciência espacializada, mecanicistamente compartimentada, mas nos homens como "corpos conscientes" e na consciência intencionada ao mundo. Não pode ser a do depósito de conteúdos, mas a da problematização dos homens em suas relações com o mundo"

(FREIRE, 2005). 


\section{- Quais as concepções de educação presentes nos jogos de papéis?}

Ao prosseguir o presente aprofundamento do referencial teórico acerca dos jogos de papéis, buscam-se os pontos de inflexão destes, como metodologias educativas, com as duas grandes concepções de educação: progressista (problematizadora) e tradicional (bancária) (FREIRE, 1992). Tais referências apresentam-se pertinentes para conduzir às questões que orientarão a análise das diversas vertentes que compõem o campo da Educação Ambiental (EA).

A educação é um campo consolidado de múltiplas teorias e uma diversidade enorme de práticas. Abordar as diversas concepções de educação foge ao escopo deste estudo, no entanto, entende-se que uma breve distinção entre as duas grandes vertentes da educação tradicional e progressista torna-se necessário. Para tal distinção utiliza-se o referencial do educador Paulo Freire, devido ao caráter original, inovador e, sobretudo, atual de seu pensamento sobre a educação brasileira e sua pertinência no tratamento das questões relativas à educação ambiental.

\subsubsection{As concepções de educação e o processo de mediatização da realidade}

Segundo Paulo Freire a educação pode servir tanto para a manutenção do sistema social, econômico vigente, quanto para a transformação do mesmo. De acordo com estes princípios, o autor desenvolve uma série de considerações sobre duas grandes formas de pensar a educação.

De um lado, tem-se a concepção bancária ${ }^{14}$ de educação, na qual o educador é o que sabe e os educandos os que não sabem, para tanto devem ser "preenchidos" como um recipiente. Esta forma de pensar e praticar a educação implica ainda num distanciamento dos sujeitos em relação ao mundo, concebe o Homem como "espectador" e não como "recriador" do mundo (FREIRE, 2005).

\footnotetext{
14 A concepção bancária de educação, segundo Paulo Freire remete à idéia de transmissão de conhecimentos e valores, na qual: "a educação é um ato de depositar, em que os educan dos são os depositários e o educador o depositante" (FREIRE,2005).
} 
'Na visão bancária da educação, o saber é uma doação dos que se julgam sábios aos que julgam nada saber. Doação que se funda numa das manifestações instrumentais da ideologia da opressão - a absolutização da ignorância, que constitui o que chamamos de alienação da ignorância, segundo a qual esta se encontra sempre no outro" (FREIRE, 2005).

Por outro lado, a concepção de educação que Freire vai defender e praticar em toda a sua trajetória, é a vertente problematizadora, na qual tanto educador e educando sabem e podem aprender sempre. O processo de educação se dá no diálogo entre educador e educando e destes com o mundo que os rodeia. Esta mediação da realidade entre educandos e educadores é o que vai constituir a "intercomunicação". Nas palavras do autor: "Ninguém educa ninguém, ninguém educa a si mesmo, os homens se educam entre si, mediatizados pelo mundo" (FREIRE, 2005).

Aqui pode se estabelecer uma semelhança com o que Paulo Freire chama de mediatização da realidade com o que, na abordagem da modelagem de acompanhamento os pesquisadores chamam de "objeto intermediário". O conhecimento, a realidade para Freire são os "mediatizadores" que possibilitam a reflexão crítica entre educador e educando; os jogos de papéis, entendidos como modelos de uma determinada realidade são entendidos como “intermediadores” entre a problemática e os sujeitos do processo. A questão que se coloca é como estes intermediadores se tornam "mediatizadores" no sentido freiriano, em busca de uma reflexão crítica sobre a problemática em questão.

Em que medida tais "objetos intermediários", (entende -se aqui os jogos de papéis sob o enfoque da modelagem de acompanhamento) são apenas de posse de quem os propõe e em que medida são compartilhados por educadores e educandos num processo dialógico? De que forma o entendimento e a compreensão deste saber inerente à concepção do modelo são compartilhados e, portanto, apropriados por todos os sujeitos do processo?

Na concepção problematizadora, o educador refaz constantemente o seu conhecimento a partir da interação com os educandos, e estes passam a ser investigadores críticos num diálogo com o educador, que também assume a postura de investigador crítico. O que se pretende com esta forma de educar é a reflexão, entre os homens e mulheres e destes com 
o mundo, caracterizada pelo exercício de "pensar-se a si mesmos e ao mundo, simultaneamente, sem dicotomizar este pensar da ação"(FREIRE, 2005).

Ao contrário, a concepção "bancária" não problematiza as relações dos sujeitos com o mundo, não explicita a relação dialética do processo, pois entende a realidade de forma estática, imobilista, única, mostrando apenas uma visão de mundo, que normalmente é a do educador, sem questionar suas origens, causas e conseqüências; sem "desvelar a realidade".

Paulo Freire entende os seres humanos como seres históricos e "inconclusos". Os homens não são, mas sim "estão sendo"; da mesma forma a realidade não é, mas "éstá sendo ", esta inconclusão dos sujeitos e da realidade permite e reforça a possibilidade de mudança, tanto do Homem, quanto da realidade (FREIRE, 1992).

Segundo o autor, "ensinar não é transferir conhecimento, mas criar as possibilidades para a sua própria produção ou a sua construção”. Nesta concepção reside a proposta problematizadora da educação. A educação mais progressista, segundo Paulo Freire exige uma série de saberes, dentre os quais a crença de que um outro mundo é possível, isto é, de que o estado da sociedade atual não é inexorável, mas sim construído por um conjunto de fatores sociais, políticos, culturais e históricos (FREIRE, 1996).

Para pensar na possibilidade de mudança, o autor salienta o fato de que a realidade de uma pessoa não é causa ou conseqüência apenas desta pessoa, individualmente, mas sim de um conjunto de fatores e de movimentos sociais, históricos, econômicos e políticos. Aqui a questão que se faz aos jogos de papéis é a seguinte: qual a dimensão individual da problemática em questão que o indivíduo, enquanto representante de um papel toma para si e o quanto esta problemática é percebida como parte de um coletivo composto por uma dinâmica entre o individual e o coletivo de todos os fatores acima mencionados?

Neste sentido é de suma importância analisar na discussão final do jogo, as estratégias individuais de cada jogador ou de um pequeno grupo de jogadores que desempenharam um determinado papel, sem esquecer que estes muitas vezes fazem parte de um coletivo e 
são apenas representantes do mesmo. Há uma tensão entre a ação individual e a coletiva, uma vez que os papéis destacados e vivenciados nos jogos de papéis tendem a exaltar a ação individual.

Metodologias participativas como os jogos de papéis que pressupõem uma vivência de uma situação-problema vão possibilitar o diálogo, resta investigar em que nível este diálogo é possibilitado através de tais metodologias. O diálogo pressupõe ainda uma relação horizontal, cabe aqui verificar o nível de participação estabelecido na relação entre educadores e educandos.

A concepção problematizadora considera o diálogo como essência do fazer educativo. Paulo Freire vai as origens do processo dialógico e entende-o como construção de uma práxis (ação e reflexão sobre a palavra). O diálogo vai além da simples comunicação entre duas pessoas, "o diálogo é este encontro dos homens, mediatizados pelo mundo, para pronunciá-lo, não se esgotando, portanto, na relação eu-tu” (FREIRE, 2005).

Neste sentido, o autor ressalta a importância de considerar a situação em que se encontram os educandos e as suas visões de mundo, numa atuação conjunta e não imposta, a partir de uma situação concreta. O conteúdo programático deve ser buscado na realidade, neste momento é que se inicia o diálogo entre educador e educando (FREIRE, 1992).

Desta forma uma metodologia problematizadora deve entender que tanto os educadores quanto os educandos são sujeitos da investigação, ambos são pesquisadores, diferente do que entendemos tradicionalmente nas práticas de pesquisa mais tradicionais. $\mathrm{O}$ educando ao se tornar sujeito do processo, assume uma postura ativa e pode então se apropriar da realidade de forma significativa (FREIRE, 2005).

\subsubsection{Reflexões sobre a Educação Ambiental e suas vertentes}

Partindo do referencial de Paulo Freire que destaca duas grandes vertentes de concepções de educação distintas, busca-se estabelecer um diálogo com as tendências de Educação Ambiental verificadas atualmente. 
Paulo Freire já colocava em suas considerações a importância de perceber o contexto ecológico dos educandos, por isso as suas idéias de educação problematizadora apresentam grande relevância no pensar a Educação Ambiental atualmente (FREIRE, 1992). O autor também destacava em suas últimas obras uma certa preocupação com a questão ambiental, então entendida como "ecologia", certamente teria desenvolvido mais este tema se tivesse tido mais tempo de vida.

O educador Celestin Freinet (1896-1966), já no início do século trazia também a idéia de "educar para o meio" como forma de estimular a aprendizagem, através dos passeio s pelo bairro e da valorização do ambiente como estratégia de estudo, além de todo o desenvolvimento de experiências práticas e colaborativas que mantinha na sua pratica pedagógica (LEONARDI, 1996).

No entanto, a Educação Ambiental (EA) compreende um campo relativamente recente que tem suas origens na problemática ambiental que começa a ser denunciada pelo movimento ambientalista na década de 60. Entretanto, atualmente e desde a sua constituição a EA apresenta cada vez mais uma diversidade e uma pluralidade de teorias e práticas que orientam suas ações e reflexões (LEONARDI, 1996; LIMA, 2002).

A Educação ambiental (EA) configura-se como um campo bastante variado composto por múltiplos entendimentos e práticas diversas. A diversidade de definições e concepções deve-se, em parte, ao fato desta ser uma prática eminentemente interdisciplinar e à amplitude da temática ambiental (TASSARA, 2001). Além das diversas concepções de Educação ambiental, encontram-se também nomeações variadas para se referir ao campo da EA: Educação para a sustentabilidade, Ecopedagogia, EA transformadora, EA crítica, emancipadora, dentre outras.

A evolução das concepções de EA está intimamente ligada às concepções de meio ambiente consideradas e à sua percepção. Neste campo podem ser encontradas desde concepções altamente conservacionistas, até concepções que consideram os aspectos sociais, entendendo a EA como educação social e política. Nas concepções mais conservacionistas, o meio ambiente é composto apenas por seus aspectos naturais - 
biológicos, físicos e ecológicos, já na concepção mais social de EA, agregam-se também as dimensões econômicas, sociais e políticas e suas interdependências, agregando as contribuições das ciências sociais (DIAS, 1992).

Lima reforça que em todo o histórico da crise ambiental, a Educação aparece como um instrumento potencial de contribuição à problemática. $\mathrm{O}$ autor afirma que ao longo dos anos 90 inicia-se o processo de maioridade da EA, a qual conquista o reconhecimento público e difunde-se numa grande quantidade de reflexões e ações promovidas em diversas instâncias (organismos internacionais, organizações não governamentais, escolas, empresas). Há então, um contexto de variadas experiências, definições teóricas, concepções pedagógicas e político-pedagógicas, embora se verifique a ausência de consensos sobre seus fundamentos e objetivos. Uma avaliação desta pluralidade de iniciativas, inicialmente pode representar um avanço na difusão da temática ambiental; entretanto, uma análise mais pormenorizada indicaria os desafios inerentes à formulação de uma teoria e prática interdisciplinares como a EA em questão (LIMA, 2002).

Em relação às diversas concepções de EA, faremos uma diferenciação das duas grandes tendências: conservacionista e crítica / emancipatória ou transformadora para situar o leitor nas possibilidades de atuação e reflexão neste campo. Tal diferenciação será também relevante para a posterior análise dos jogos de papéis no capítulo de discussão dos resultados da pesquisa.

A vertente de EA que pretendemos enfatizar e através da qual faremos a análise das metodologias, é uma visão da EA crítica, transformadora e emancipatória (TASSARA, 2001; REIGOTA, 1999; LIMA, 2002). Esta vertente contrapõe-se à visão conservadora da EA pautada principalmente na transmissão de informações e conceitos ecológicos, que mais se preocupa com os efeitos dos problemas ambientais do que com suas causas. A EA crítica / transformadora pressupõe a problematização das questões socioambientais buscando suas inter-relações e propondo novos olhares e mudanças de comportamento e valores individuais e coletivos, além da participação na resolução dos problemas de forma ativa e engajada. 
De acordo com as possibilidades conservadoras e transformadoras da escola e da educação em geral, teremos na primeira orientação, uma prática de EA pautada na transmissão de conhecimentos recentes em Ecologia, uma "educação ecológica" que pouco considera um questionamento sobre as raízes dos problemas ambientais. Neste contexto situam-se as práticas que levam à "biologização" da questão ambiental, na qual as questões sociais, históricas e econômicas não são totalmente incluídas. Já na segunda orientação, situam-se intervenções que vão além de pensar os efeitos de um problema ou questão ambiental momentânea para também questionar as origens do problema, desvelando aspectos não visíveis da realidade em questão.

Lima utiliza os seguintes critérios para distinguir a EA conservadora da crítica e emancipatória: a) perspectiva de mudança social - para indicar o potencial de conservação ou transformação; b) o grau de integração - para sinalizar o nível de complexidade ou o reducionismo na abordagem das questões e c) o compromisso social, que mostrará a orientação comunitária/ individualista (LIMA, 2002). A partir dos critérios acima citados, o autor caracteriza as duas grandes vertentes de EA que foram agrupadas no quadro abaixo para facilitar a visualização.

Quadro 2 - Características da EA conservadora e emancipatória.

\begin{tabular}{|l|l|}
\hline EA conservadora & EA crítica / emancipatória \\
\hline $\begin{array}{l}\text { Concepção reducionista, fragmentada e } \\
\text { unilateral da questão ambiental }\end{array}$ & $\begin{array}{l}\text { Compreensão complexa e } \\
\text { multidimensional da questão ambiental }\end{array}$ \\
\hline Compreensão naturalista da crise ambiental & $\begin{array}{l}\text { Defesa do amplo desenvolvimento das } \\
\text { liberdades humanas e não humanas }\end{array}$ \\
\hline $\begin{array}{l}\text { Tendência a sobrevalorizar respostas } \\
\text { tecnológicas diante dos desafios ambientais }\end{array}$ & $\begin{array}{l}\text { Associação dos argumentos técnico- } \\
\text { científicos à orientação ética do } \\
\text { conhecimento }\end{array}$ \\
\hline $\begin{array}{l}\text { Leitura individualista e comportamentalista } \\
\text { da educação e dos problemas ambientais }\end{array}$ & $\begin{array}{l}\text { Cuidado em estimular o diálogo e a } \\
\text { complementaridade - interesses individuais } \\
\text { e coletivos }\end{array}$ \\
\hline $\begin{array}{l}\text { Abordagem despolitizada da questão } \\
\text { ambiental }\end{array}$ & $\begin{array}{l}\text { Politização e publicização da problemática } \\
\text { sócio-ambiental }\end{array}$ \\
\hline $\begin{array}{l}\text { Baixa incorporação de princípios e práticas } \\
\text { interdisciplinares }\end{array}$ & $\begin{array}{l}\text { A democracia como pré-requisito } \\
\text { fundamental para a construção da } \\
\text { sustentabilidade }\end{array}$ \\
\hline Perspectiva crítica limitada ou inexistente & $\begin{array}{l}\text { Atitude crítica diante dos desafios da crise } \\
\text { civilizatória }\end{array}$ \\
\hline
\end{tabular}


Separação das dimensões sociais e naturais da problemática ambiental
Exercício da participação social e defesa da cidadania como práticas indispensáveis à democracia e à emancipação sócioambiental

Fonte: LIMA, 2002

Reconhecer as diferentes concepção e orientação da EA é um primeiro requisito para se pensar em metodologias e práticas no campo. A tendência emancipatória ou transformadora da EA vai reconhecer nas questões ambientais suas dimensões políticas, compreendendo a problemática ambiental como uma expressão de conflitos entre interesses públicos e privados (LIMA, 2002).

O referido autor complementa que a vertente conservacionista esteve pautada no movimento conservacionista norte-americano, antropocêntrico e utilitarista, que busca o uso racional dos recursos naturais, numa conservação que não interfira nas ativdades econômicas e nas estruturas de produção do sistema (LIMA, 2002).

Ao defender uma EA política e transformadora, Reigota reafirma que a competência técnica, ou seja, a informação e o conhecimento necessários sobre a problemática ambiental em questão são tão fundamentais quanto a compreensão de suas implicações sociais, culturais, econômicas e até pessoais (REIGOTA, 1999).

Neste sentido, politizar a EA significa reconhecer e explicitar os conflitos originários das questões ambientais, reconhecer o educando como portador de direitos e deveres; entender o meio ambiente como bem público e o acesso a um ambiente saudável como um direito de cidadania e, finalmente, a participação como prática. A participação entendida como conquista, não como dádiva ou concessão (DEMO, 1999 apud LIMA, 2002).

Sorrentino reafirma a importância de possibilitar uma participação dos segmentos mais marginalizados da sociedade - jovens, mulheres, negros, idosos, crianças, a periferia, as diversas minorias - que ultrapasse a presença física em reuniões e se manifeste nas atitudes e comportamentos, a partir da negociação, da descentralização, do enraizamento, e finalmente, da auto-gestão. O autor define alguns passos necessários à viabilidade da 
participação, são estes: 1) fornecer-lhes informações, 2) criar ou apontar espaços de locução e troca efetiva, 3) definir mecanismos claros de tomada de decisão e 4) possibilitar-lhes condições objetivas de participação efetiva, tais como horários livres, facilidade de deslocamento (SORRENTINO, 2002).

No sentido de uma educação para a cidadania, a educação ambiental vai aparecer não apenas numa perspectiva conservacionista, sensibilizando sobre a necessidade de conservação dos recursos naturais, mas promovendo uma autonomia dos atores sociais ("empowerment") que possa viabilizar esse projeto político, numa perspectiva emancipadora de educação ambiental. A construção da cidadania ${ }^{15}$, o fortalecimento da democracia e a promoção da justiça social são os fundamentos necessários para a implementação, tanto da Política Nacional de Recursos Hídricos, quanto da educação ambiental (SAITO, 2002).

Loureiro inclui a adjetivação "transformadora" na Educação ambiental entendendo -a como uma abordagem similar à vertente emancipatória citada anteriormente e explicita os motivos de uma adjetivação ambiental à própria educação, a saber:

O referido autor complementa que as origens da Educação Ambiental Transformadora remetem à década de 80 , com a participação de educadores ligados à educação popular e aos movimentos ambientalistas e sociais com foco na transformação da sociedade a partir da crítica ao modelo de desenvolvimento. Neste campo apresenta notável influência a obra de Paulo Freire e suas propostas libertárias de uma educação pautada na problematização e no diálogo (LOUREIRO, 2004).

Loureiro afirma ainda que as múltiplas vertentes presentes no campo da EA, já se configuravam, de certa forma, desde a origem do movimento. $\mathrm{O}$ autor alerta para o fato de pensar o desenvolvimento das concepções como um processo linear, originariamente pautado por uma tendência conservacionista e posteriormente, atingindo uma abordagem transformadora. O processo caracteriza-se por algo plural, manifestando diversas tensões.

\footnotetext{
${ }^{15}$ cidadania é aqui entendida como aquela relacionada com o surgimento da vida na cidade, à capacidade de os homens exercerem direitos e deveres de cidadão. Na atuação de cada indivíduo, há uma esfera privada (particular) e uma esfera pública (que diz respeito a tudo que é comum a todos os cidadãos ) In: Covre, M.L.M. O que é cidadania, ed Brasiliense, 1991:18.
} 
O autor também ressalta que a temática ambiental e, conseqüentemente, a EA chegaram no Brasil na década de 70, quando o país encontrava-se sob a ditadura militar e, sob tal pressão era preciso evitar a demasiada "politização dos espaços educativos" (LOUREIRO, 2004).

Tassara utiliza a mesma denominação de EA transformadora e destaca a importância do papel do educador como "um grande mediador das transformações sociais, entre as quais, naturalmente, a emergência de uma consciência ambientalista”. O educador neste processo poderá então contribuir para que as pessoas encontrem caminhos de transformação de suas próprias condições de vida e também da sociedade em geral, "uma possibilidade única de reconstruir nossa história e nossa relação com a natureza”, nas palavras da autora (TASSARA, 2001). Neste sentido, a EA pautada na vertente transformadora vai mais na direção de compartilhar idéias e conceitos do que de fornecer respostas prontas, exigindo a motivação para a reflexão através de olhares diversos.

Acrescentando algumas considerações no âmbito da concepção "transformadora" da EA, Carvalho utiliza a denominação Educação Ambiental Crítica e enumera alguns princípios sobre esta vertente, dos quais destacamos: a compreensão do ambiente e dos problemas ambientais em suas múltiplas dimensões - geográficas, históricas, biológicas, sociais aliando o conhecimento cientifico ao conhecimento popular. A autora indica ainda os princípios do processo de ensino-aprendizagem de uma EA crítica, tais como: possibilitar uma aprendizagem significativa a partir das vivências e da ampliação do repertório, bem como implicar os sujeitos na resolução e na melhoria dos conflitos e problemas locais. Para atingir tais objetivos o educador deve assumir uma postura de mediador das relações sócio-educativas incitando os educandos à pesquisa, à reflexão e possibilitando novos processos de aprendizagem (CARVALHO, 2004).

Guimarães utiliza também a denominação EA Crítica apresentando diversas semelhanças às abordagens anteriormente citadas. $\mathrm{O}$ autor traz a necessidade de qualificar a EA como crítica para indicar uma possibilidade educativa que vise à transformação da realidade, em oposição à educação ambiental de caráter conservador. Tal prática conservadora tem sido bastante verificada no ambiente escolar (ensino formal), devido ao que o autor 
chama de "armadilh a paradigmática", ou seja, à reprodução de ações educativas tradicionais, de forma inconsciente, pelos professores que não apostam na criatividade ou na inovação. As práticas pedagógicas pertinentes à EA Crítica devem romper com esta “armadilha paradigmáti ca”, envolvendo os educandos de forma racional e também afetiva, buscando motivá-los para a causa ambiental. (GUIMARÃES, 2004).

Neste sentido, Guimarães faz referência às interfaces da Educação Ambiental com a Educação Popular, uma vez que o processo educativo não se restringe aos limites da escola. Educação Popular pode ser aqui entendida como uma educação não-formal, desnvolvida fora dos limites da escola, em vários espaços, o termo popular também remete ao processo educativo das décadas de 60 e 70 relacionados à formação dos movimentos populares.

Finalmente uma outra denominação de uma prática educativa semelhante à EA é a denominada Ecopedagogia. A Ecopedagogia também partilha da concepção de Educação transformadora, no sentido da possibilidade de mudança da realidade, segundo Paulo Freire. Uma grande parte dos autores de referência da desta vertente são seguidores do legado freireano. Francisco Gutierrez, o idealizador do termo Ecopedagogia, utiliza a seguinte definição: "uma concepção dinâmica, criadora e relacional de educação, um processo de elaboração de sentidos no cotidiano das pessoas" (GUTIERREZ, 2000 apud AVANZI, 2004).

A representação de natureza / meio ambiente que serve de base a Ecopedagogia, inclui as dimensões espirituais e o caráter holístico, inspira-se em autores como Fritjof Capra e Leonardo Boff. Uma das críticas que os adeptos desta vertente fazem à EA situa-se em relação à representação de meio ambiente, distante das questões sociais e limitadas ao ambiente externo. Os autores afirmam que a Ecopedagogia não seria contrária à EA, mas sim, mais abrangente, o que é verificado nos textos é a necessidade desta abordagem reconhecer-se contrária a um tipo de EA em particular, caracterizado pela vertente mais conservacionista (AVANZI, 2004). 
Em resumo, a educação é um "subsistema" subordinado e articulado ao sistema social maior e vigente, portanto, a evolução das concepções de EA estão, de certa forma, relacionadas aos debates do campo do ambientalismo e da sustentabilidade, assumindo variações em torno do conservadorismo e da emancipação (CARVALHO, 1998; LIMA, 2002).

\subsubsection{Sobre a criação do termo "Educação ambiental"}

Atualmente com o surgimento de novas terminologias que compartilham idéias com a EA, nota-se uma forte discussão em relação à criação do termo Educação ambiental para caracterizar um novo tipo de educação. Alguns autores alegam que se a educação cumprisse bem o seu papel de forma integral, não precisaríamos de tal especificação. Entretanto, torna-se necessário especificar a Educação ambiental como um movimento pedagógico que surge principalmente na América Latina e no Brasil intrinsecamente ligado à crítica social dos movimentos ecológicos, no âmbito da difusão da problemática ambiental na sociedade (CARVALHO, 2002).

Carvalho atribui uma função substantiva ao atributo ambiental da Educação ambiental. Segundo a autora, este termo não é apenas um adjetivo para caracterizar um tipo particular de educação. Neste caso, o atributo assume uma função substantiva ao identificar uma concepção de educação que surge num contexto histórico determinado pelos movimentos sociais ambientais e sua possibilidade de crítica a uma cultura estabelecida, ou seja, suas raízes contra-culturais (CARVALHO, 2002).

Lima destaca que no discurso de alguns educadores ambientais, principalmente os oriundos das "ciências naturais" com pouca formação pedagógica, a EA aparece como algo muito inovador pautado na "ilusão pedagógica", de que a Educação, no caso a EA é solução para toda a crise atual. Tal concepção explicita uma certa fragilidade teóricometodologica da EA e a falta de diálogo com todo o campo de conhecimento acumulado na educação (LIMA, 2002). No entanto, em seu estudo o autor nota um certo amadurecimento do campo a partir de 1995, o que não vem sanar a falta de estudos sistematizados e de diagnósticos da realidade brasileira em relação à identidade do educador ambiental e de suas práticas e reflexões. 
Diversos trabalhos já abordaram o histórico detalhado da EA, não seria necessário aqui fazê-lo novamente (LAYRARGUES, 1999; CARVALHO, 2002; LIMA, 2002). Inserimos um breve histórico da EA como apêndice desta dissertação, assim, o leitor que manifestar interesse terá uma retrospectiva mais aprofundada (vide apêndice). O texto apenas pretende situar o leitor da trajetória de criação do campo que se convencionou chamar de Educação Ambiental.

É importante ressaltar os príncipios e suas modificações ao longo do tempo, sempre lembrando do seu contexto histórico, político e social da época.

\subsubsection{Algumas considerações sobre as metodologias de EA}

Os trabalhos de avaliação das metodologias utilizadas na Educação Ambiental não são muitos, há uma carência de diagnósticos e avaliações de projetos sistematizadas (LIMA, 2002). No entanto, como o foco desta pesquisa reside na análise de um tipo de metodologia de gestão ambiental, algumas considerações sobre os possíveis recursos metodológicos parecem relevantes.

As metodologias da EA são igualmente tão diversas e múltiplas quanto às suas concepções, são verificados os métodos: passivo (em que só o educador fala), ativo (em que os alunos participam da discussão do tema), descritivo (descrevem o que puderam observar numa excursão ou estudo do meio, por exemplo) e analítico (respondem a uma série de questões sobre o tema). A EA que pretende promover a participação deve utilizar metodologias participativas que levem o educando a questionar dados e idéias sobre o tema em discussão, adotando, em grande parte da intervenção um método ativo. Neste sentido, o componente reflexivo das metodologias propostas é igualmente essencial ao processo (REIGOTA, 1994).

Da mesma forma, Loureiro afirma que, em se tratando de uma EA Transformadora, pautada na abordagem da complexidade e da interdisciplinaridade, as metodologias participativas são as mais adequadas ao processo educativo. Tais metodologias começaram a ser utilizadas no final do século XIX, nas pesquisas sociais e tornaram-se mais significativas com as práticas da pesquisa-ação, pesquisa participante e de educação 
popular. $\mathrm{O}$ autor identifica alguns objetivos norteadores de tais metodologias no campo da educação, a saber: contribuir para o exercício da cidadania; promover a consciência crítica, através de uma abordagem integrada dos problemas; estimular a manifestação de todos os envolvidos no processo e vincular os processos de formação com atividades econômicas e políticas (LOUREIRO, 2004).

Silva ressalta que as metodologias da Educação Ambiental brasileira apresentam uma forte tendência empírica e personalizada, na medida que cada educador desenvolve uma metodologia, na maioria das vezes, bastante ligada à realidade local, bem particular. Em um estudo realizado em 1997, o autor verificou a presença da participação comunitária e do diagnóstico participativo em várias atividades. Nos projetos analisados, a discussão em grupo aparecera como uma das técnicas mais utilizadas, seguida por técnicas expositivas adotando o construtivismo ${ }^{16}$ como prática pedagógica (SILVA, 2000).

Segundo Tassara, as intervenções educativas na área ambiental devem desenvolver conhecimentos, valores, atitudes e comportamentos, habilidades essenciais à participação e à emancipação (TASSARA, 2001).

Layrargues aponta a resolução de problemas ambientais locais como uma potencial estratégia educativa, citando a seguinte recomendação da Conferência de Tbilisi, 1980:

"A característica mais importante da educação ambiental é, provavelmente, a que aponta para a resolução de problemas concretos. Trata-se de que os indivíduos, qualquer que seja o grupo da população a que pertençam e o nível em que se situem, percebam, claramente, os problemas que restringem o bem-estar individual e coletivo, elucidem as suas causas e determinem os modos de resolvê-los. Deste modo, os indivíduos estarão em condições de participar na definição coletiva de estratégias(....)”

(UNESCO, 1980 apud LAYRARGUES,1999)

No entanto, a estratégia metodológica de resolução de problemas locais, pode ser, segundo Layrargues uma atividade-fim ou uma atividade-meio (tema gerador). Como

\footnotetext{
${ }^{16}$ Construtivismo: De acordo com a concepção construtivista, o ensino é um processo compartilhado entre aluno e professor, no qual o primeiro vai adquirindo, de forma progressiva, competências e autonomia na resolução de tarefas, na utilização de conceitos e em diversas questões (COLL ,1996)
} 
tema-gerador, a atividade abre novas possibilidades à transformação e à compreensão da realidade, ao passo que como atividade-fim existe apenas a resolução pontual do problema em questão. Utilizar a concepção de tema-gerador pressupõe entender a crise ambiental como uma cadeia de relações num sistema complexo pautado por conflitos, enquanto a de atividade-fim entende uma ação destinada a resolver problemas ambientais específicos, pontuais, isolados do sistema (LAYRARGUES, 1999).

Os jogos de papéis no contexto da Educação Ambiental devem ser considerados, portanto, atividades-meio e não atividades-fim, na medida em que iniciam uma discussão ou sintetizam um conteúdo abordado. O jogo, será então, uma das metodologias utilizadas no processo de formação que envolve uma ampla variedade de ações e reflexões.

Paulo Freire também desenvolveu o conceito de tema gerador. Como ponto de partida do processo de alfabetização, este consistia num tema que fizesse sentido à realidade local dos educandos e que a partir dele, trouxesse novos questionamentos sobre as causas dos problemas enfrentados na realidade. Desta forma, o sujeito estaria sendo alfabetizado na leitura das palavras em consonância com a "leitura do mundo"(FREIRE, 1996).

O sentido de "leitura de mundo" remete à idéia de observar a realidade local trazida por Paulo Freire, em seu projeto de Alfabetização de Adultos na Educação popular. O autor destaca a importância não só de aprender a "leitura da palavra", mas igualmente de aprender a ler a realidade, de forma que as palavras tenham um sentido no contexto dos educandos (FREIRE,1992). Paulo Freire ressalta que qualquer metodologia, por mais progressista que seja, só terá valor se os educandos estiverem dispostos a participar.

'Que não seja uma prática imposta, autoritária, por mais nobres que sejam as intenções de quem a propõe. Não adianta pensar nos melhores conteúdos programáticos se aquilo não fizer sentido, se não motivar os educandos. Neste sentido, entende-se por metodologias participativas aquelas que discutem com o público-alvo os conteúdos abordados e então incorporam suas sugestões e críticas, provocando então um questionamento conjunto, uma reflexão sobre o tema orientada em conjunto por educadores e educandos, de forma crítica e reflexiva "

(FREIRE, 1992) 
As metodologias participativas ganharam uma grande difusão no Brasil a partir das eleições diretas, em 1985 e vêm se consolidando desde os anos 90. Atualmente verificase a existência de diversos métodos participativos utilizados nos setores: público e terceiro setor (organizações não governamentais). As técnicas são diversificadas: o diagnóstico rural participativo(DRP), o planejamento municipal participativo(PMP), a capacitação de empreendedores(CEFE), o planejamento do projeto orientado pelos objetivos(ZOOP), a visualização móvel(METAPLAN), dentre outras (BROSE, 2001). O autor distingue ainda os termos: metodologia, que se refere ao estudo dos métodos e método que se caracteriza pelo próprio instrumento. O método participativo muitas vezes envolve a utilização de vários instrumentos que acabam por receber a denominação de metodologias participativas.

Uma análise mais aprofundada do tema não se deve limitar apenas aos instrumentos, métodos e técnicas, mas também introduzir a questão central que se remete à própria participação que diz respeito às disputas em relação ao poder. 'Instrumentos participativos tem como função principal ajudar a estruturar as disputas sobre poder entre atores sociais, torná-las mais transparentes e, contribuir para uma distribuição mais eqüitativa do poder" (BROSE, 2001). Esta questão da participação, conforme desenvolvida anteriormente, deve considerar também o nível de horizontalidade estabelecido no processo, o que vai corresponder ao nível de participação cidadã vivenciado em cada uma das etapas do projeto (ARNSTEIN, 1969).

Ao longo deste capítulo procuramos demonstrar algumas das possibilidades de diálogo de uma abordagem dos jogos de papéis, a qual vem sendo utilizada como metodologia participativa na gestão dos recursos naturais, com os referenciais da Educação Ambiental, numa proposta problematizadora e progressista de Educação.

No que diz respeito aos jogos de papéis em particular e ao jogo de um modo geral a literatura é bastante extensa. Vários são os autores que apostam na questão do lúdico como forma de promover um aprendizado mais significativo e próximo à realidade dos educandos. Na temática da EA, visando uma educação para a participação, as questões 
suscitadas são de um alto nível de complexidade, procuramos explicitar algumas sem a pretensão de esgotá-las totalmente. O exercício de refletir sobre metodologias de tal complexidade deve sempre ressaltar o fato de que são metodologias, e, como tal, para serem analisadas é necessário que estejam inseridas num contexto educativo mais amplo. As reflexões sobre Educação nos levam a questionar as possibilidades e os limites de metodologias didáticas como os jogos de papéis aqui analisados em relação às perspectivas da Educação Ambiental em sua vertente mais crítica.

A seguir apresentamos a pesquisa realizada, buscando uma metodologia adequada para responder às questões de pesquisa construídas a partir do referencial teórico explicitado. 


\section{A PESQUiSA REALIZADA: QUESTÕES, HIPÓTESES E METODOLOGIA. APRESENTAÇÃO DOS JOGOS ESTUDADOS}

Nos capítulos anteriores explicitamos a problemática do contexto e os referenciais teóricos que orientam este estudo. Neste capítulo explicitam-se os referenciais metodológicos que serviram de base para o desenvolvimento da pesquisa.

Iniciamos o capítulo com as questões de pesquisa que destacamos a partir da literatura referente às vertentes da Educação Ambiental e da inserção dos jogos de papéis no contexto de formação.

Em seguida, explicamos os procedimentos de pesquisa, os quais estão divididos em duas fases: 1) a comparação de experiências brasileiras de formação com ênfase nas questões de uso e ocupação do solo e da água em regiões urbanas, 2) a análise das sessões de teste do Jogo dos Mananciais -um jogo de papéis com simulação de cenários (protótipo de jogo $(o m M o d)$, uma intervenção desenvolvida no Projeto Negowat, na qual foi possível um maior acompanhamento na elaboração e no monitoramento.

Vale ressaltar que as duas etapas de pesquisa estão intrinsecamente relacionadas e foram fundamentais para o desenvolvimento da mesma. Não teria sido possível perceber e evidenciar as especificidades dos jogos de papéis com enfoque na modelagem de acompanhamento sem resgatar as experiências já desenvolvidas no contexto de formação em relação à problemática de gestão ambiental e urbana.

\subsection{A CONSTRUÇÃo DAS QUESTÕES DE PESQUISA E HIPÓTESES}

De acordo com os referenciais teóricos selecionados e explicitados ao longo do capítulo teórico, desenvolvemos duas grandes questões de pesquisa a fim de orientar a análise das experiências de jogos de papéis estudadas.

1) Quais são os potenciais e os limites dos jogos de papéis em geral, no âmbito de uma EA crítica?

2) Quais as contribuições dos jogos de papéis com simulação de cenários, desenvolvidos a partir do enfoque da modelagem de acompanhamento, para a EA 
crítica? O que ainda precisa ser aprimorado para que jogos de papéis ComMod participem como instrumentos didáticos de processos de EA crítica?

Para responder às questões de pesquisa acima citadas, partimos das seguintes hipóteses:

1) Os jogos de papéis, por sua estrutura complexa, seu caráter lúdico e dinâmico, pode ser uma metodologia participativa adequada em projetos de EA, na formação de representantes de comunidades locais ou de educadores ambientais para a discussão da importância da negociação e da participação comunitária na gestão dos recursos hídricos;

2) A abordagem da modelagem de acompanhamento através da simulação de cenários e da interação de diversos atores presentes jogos de papéis pode contribuir na explicitação da problemática ambiental complexa inerente à questão da ocupação urbana e da conservação das áreas de mananciais na RMSP, embora ainda seja uma proposta de difícil entendimento e elevada complexidade.

Deve-se ressaltar, contudo, que o jogo de papéis será considerado como um dos elementos do processo de educação e, como tal, o desafio de analisá-lo de forma isolada apresenta suas limitações.

\subsection{MetOdologia DE PESQUisa}

O referencial metodológico utilizado nesta pesquisa baseia-se na análise qualitativa (AlVES, 1991; LUDKE, 1986) buscando a compreensão das inter-relações que emergem de um dado contexto e pautado nos princípios da pesquisa-ação (BARBIER, 2002; ELLIOT, 1991; BRANDÃO, 1981; THIOLLENT,1986 ).

A pesquisa terá como base a observação participante tanto de algumas de algumas sessões dos jogos de papéis selecionados, quanto do acompanhamento dos processos desenvolvidos no âmbito do Projeto Negowat. Em destaque a oservação participante das sessões do Jogo dos Mananciais. 
A base para o monitoramento das sessões do Jogo dos Mananciais, bem como a reformulação e transposição didática de todo o material do jogo foram desenvolvidas durante a participação nas propostas de intervenção realizadas ao longo do projeto.

\subsubsection{Procedimentos de pesquisa e critérios de análise}

Os procedimentos de pesquisa foram divididos em duas etapas, descritas em detalhe no quadro abaixo:

1) Levantamento e comparação de algumas experiências brasileiras que utilizam jogos de papéis na área ambiental e urbana;

2) Análise das percepções dos jogadores em relação ao Jogo dos Mananciais, protótipo de jogo de papéis com simulação, desenvolvido no Projeto Negowat;

Quadro 3 - Descrição das etapas da pesquisa.

\begin{tabular}{|l|l|c|}
\hline \multicolumn{1}{|c|}{ Etapas da pesquisa } & \multicolumn{1}{|c|}{ Procedimentos } & \multicolumn{1}{|c|}{ Jogos } \\
\hline $\begin{array}{l}\text { 1 Levantamento de } \\
\text { experiências brasileiras, } \\
\text { comparação e uma breve } \\
\text { análise }\end{array}$ & $\begin{array}{l}\text { 1.Análise do material de jogo (tabuleiros, fichas, cartas) } \\
\text { 2.Entrevistas com os autores }\end{array}$ & EC \\
\hline $\begin{array}{l}\text { 2.Participação numa sessão de jogo, quando possível } \\
\text { Manancise do Jogo dos } \\
\text { com simulação, através das } \\
\text { percepções de um público } \\
\text { estudante }\end{array}$ & $\begin{array}{l}\text { 1.Análise dos conhecimentos prévios a partir de um } \\
\text { questionário inicial (aplicado apenas nas duas últimas sessões } \\
\text { de teste) }\end{array}$ & DA \\
\hline $\begin{array}{l}\text { 2.Análise dos questionários finais (aplicados em todas as } \\
\text { sessões de jogo) }\end{array}$ & Jogo dos \\
& $\begin{array}{l}\text { 3. Aplicação de questionários finais e iniciais (algumas } \\
\text { sessões) } \\
\text { 4. Análise da fase final da sessão de jogo } \\
\text { 5. Observação participante }\end{array}$ & Mananciais \\
\hline
\end{tabular}

Fonte: elaborado pela autora.

\subsubsection{Levantamento e comparação de algumas experiências brasileiras que utilizam jogos de papéis na área ambiental e urbana}

A primeira etapa da pesquisa teve como objetivo geral conhecer e sistematizar o que tem sido realizado em projetos de formação em Educação Popular e Ambiental em relação à utilização de jogos de papéis (RPG). Tal procedimento foi também fundamental para explicitar as semelhanças e diferenças que existem entre estas experiências tradicionais 
de jogos de papéis e os jogos de papéis desenvolvidos a partir do enfoque da modelagem de acompanhamento, os quais são alvo da intervenção do projeto de pesquisa Negowat.

Foram selecionados quatro jogos de papéis, sendo três relacionados à problemática da ocupação do solo e questões de moradia (Jogo do Estatuto da Cidade - EC; Jogo da Regularização fundiária - REG e Jogo da Construção do espaço urbano - CEU) e um relacionado explicitamente às questões de uso e ocupação do solo e da água (Desafio das Águas - DA ). A descrição dos jogos em detalhe pode ser visualizada ao final do texto.

A seleção dos jogos de papéis foi baseada em indicações dos próprios autores e seus conhecimentos de experiências desenvolvidas na área que abordam questões complexas relacionadas à gestão ambiental e urbana. Os jogos exploram a problemática das questões urbanas relativas à questão de moradia e especulação fundiária nas grandes cidades, as quais estão intrinsecamente interligadas às questões relativas à problemática dos recursos hídricos na bacia hidrográfica do Alto Tietê, São Paulo, nosso foco de estudo.

Deve-se ressaltar também que por serem da mesma área de atuação, os autores dos três jogos de papéis da temática da gestão urbana (EC, REG e CEU) estão muito articulados, uma vez que as organizações que desenvolveram as ferramentas mantêm um trabalho próximo e de certa forma integrado relacionado às políticas públicas e ao direito à moradia.

Para a análise dos jogos foi utilizado um conjunto de referências de pesquisadores que desenvolveram avaliações, análises e comparações de metodologias de gestão participativa na área ambiental e também materiais didáticos de EA (HARE; PAHLWOSTL, 2004; JUNQUEIRA, 1999; TRAJBER, 1999; ULRICH, 1997, FJERMESTAD, 1997, MAUREL, 2003).

Como o jogo de papéis é aqui entendido como uma dinâmica de grupo, alguns critérios de análise desses processos foram bastante pertinentes para análise dos jogos selecionados. 
Numa estrutura de análise mais geral para os sistemas de suporte aos processos de grupo, destacam-se três grandes critérios (McGrath,1984 apud TUNG,1998):

1) variáveis do contexto que incluem a estrutura do grupo, as características das tarefas solicitadas nos vários encontros do grupo, fatores situacionais e o suporte tecnológico;

2) o processo de grupo em si;

3) os produtos ou resultados do processo.

Fjermestad faz uma avaliação crítica de artigos publicados em revistas da área de sobre o estudo de sistemas de apoio à decisão em grupo e define então uma metodologia de comparação com quatro categorias de variáveis (FJERMESTAD, 1997):

1) tecnologia de suporte utilizada;

2) as variáveis relativas ao grupo, tais como: o tamanho, a composição e as características dos membros do grupo;

3) as tarefas ou objetivos a serem alcançados pelo grupo;

4) o contexto

Para a análise dos jogos selecionados, primeiramente reunimos um conjunto de materiais que compõem cada um dos jogos, tais como material do jogo (manuais, cartas, tabuleiros, fichas) e também outros materiais de referência disponíveis - relatórios e publicações. Em seguida, realizamos entrevistas com os autores ou com a equipe responsável pelo desenvolvimento do jogo e por fim a observação de uma sessão de jogo quando possível.

O acompanhamento de sessões de jogo foi um dos fatores limitantes da pesquisa, uma vez que não foi possível assistir a todas as sessões de jogo. Conseguimos apenas participar de uma sessão de jogo do Estatuto da Cidade (EC) e da Regularização (REG). Não foi possível assistir às sessões do Desafio das Águas (DA) nem do jogo da Construção do Espaço Urbano (CEU), o que, de certa forma limita o nosso aprofundamento em relação à análise desses jogos. Neste sentido, percebemos os limites da análise destes jogos, o que difere da análise do Jogo dos Manaciais, no qual a participação esteve desde à elaboração do material didático, até a aplicação do jogo. 
Entretanto, a partir dos outros recursos utilizados na análise, esperamos apresentar um panorama das possibilidades e objetivos diversos que os jogos de papéis podem oferecer como metodologia didática, sem a pretensão de formular propostas que carecem de um acompanhamento mais sistemático sobre o processo de jogo completo.

$\mathrm{Na}$ análise dos jogos foi possível comparar as variáveis do contexto e perceber um pouco do processo de grupo, através da observação de algumas das sessões em particular e de relatos dos autores. Os impactos ou produtos gerados não entram nesta análise, uma vez que para tal seria necessária uma avaliação de impacto dos projetos em longo prazo, o que não estava ao nosso alcance nesta pesquisa. Da mesma forma, o acompanhamento das sessões de jogo foi possível, apenas, na análise do Jogo dos Mananciais, já que neste, o acompanhamento foi mais próximo e o número de sessões observadas também superior aos demais. Essa análise será detalhada no próximo capítulo da dissertação. De toda maneira, os aspectos de jogo referentes às sessões observadas serão destacados na análise dos resultados.

De acordo com a literatura, selecionamos alguns critérios pertinentes à comparação dos jogos, os quais serão explicitados na análise dos resultados. A partir deste referencial metodológico conseguimos estabelecer uma comparação entre os quatro jogos de papéis selecionados para o estudo. A partir da comparação chegamos às inflexões com a proposta de Educação Ambiental. Estes pontos serão explicitados na discussão das questões de pesquisa.

\subsubsection{Análise das percepções dos jogadores em relação ao Jogo dos Mananciais, protótipo de jogo de papéis com simulação desenvolvido no Projeto Negowat}

Em relação à segunda etapa da pesquisa, foram realizadas cinco sessões-teste do Jogo dos Mananciais para validação e aprimoramento do material de jogo. As duas primeiras desenvolveram-se com estudantes de nível superior (graduação) em cursos da área de Ciências Biológicas em faculdades e universidades privadas e as sessões subseqüentes com estudantes de pós-graduação em cursos da área ambiental de enfoque multidisciplinar de duas universidades da rede pública e uma da rede particular. 
Vale ressaltar que o "Jogo dos Mananciais" corresponde à primeira experiência de pesquisa e intervenção desenvolvida no Projeto Negowat com enfoque na abordagem da modelagem de acompanhamento.

Para a análise do Jogo dos Mananciais foram aplicados questionários aos participantes. Da mesma forma, foram objeto de análise as discussões provenientes da análise final do jogo (ou debriefing ${ }^{17}$ ) que consiste em relatos dos jogadores sobre a situação vivenciada e a observação e a mediação das sessões de jogo.

Os questionários apresentavam como principal objetivo captar as percepções dos participantes em relação à sessão de jogo que haviam participado.

Neste sentido, os questionários traziam questões relativas aos aspectos do jogo tais como as impressões sobre o material e a vivência de jogo, as maiores dificuldades encontradas em relação à dinâmica, as impressões sobre a vivência de uma simulação de reunião do Comitê de Bacia. As questões abordavam ainda as críticas e sugestões ao material de jogo, as quais foram fundamentais para o aprimoramento do material ao longo do processo e finalmente, as peculiaridades do jogo de papéis - Jogo dos Mananciais - em relação a outras dinâmicas de grupo já vivenciadas (vide questionário em anexo).

Para a análise dos questionários, utilizamos cinco variáveis que depois se desdobraram em diversas categorias: 1) Aspectos do jogo; 2) Dificuldades em relação ao jogo; 3) Grau de conhecimento do Comitê de Bacia; 4) Aprendizados sobre a gestão dos recursos hídricos e 5) Aprendizados sobre negociação.

\footnotetext{
${ }^{17}$ debriefing é o termo em inglês utilizado para designar a analise final de uma sessão de jogo de papéis. Esta fase do jogo é bastante explorada por diversos autores da área, que a consideram uma das etapas mais importantes do jogo de papéis (PETERS; VISSERS, 2003, DORN, 1989).
} 


\subsection{APRESENTAÇÃO DOS JOGOS ESTUDADOS}

Apresentamos brevemente as características de cada um dos jogos para situar o leitor na

problemática em questão. Para facilitar a descrição elaboramos "fichas de identificação dos jogos" com as informações principais e a explicação da dinâmica de jogo. 


\subsubsection{Jogo "Desafio das Águas" (DA)}

Nome: Desafio das Águas

Autor: Instituto Ecoar para a Cidadania (ONG SP), 1999

Objetivos : projeto de educação ambiental para a formação sobre a gestão integrada dos recursos hídricos

Público-alvo: membros dos 6 sub-comitês e atores locais da bacia do Alto Tietê, SP

Número de jogadores: 4 a 8 jogadores
Figura 7 - Visão parcial do Tabuleiro do Jogo “Desafio das Águas”(DA)

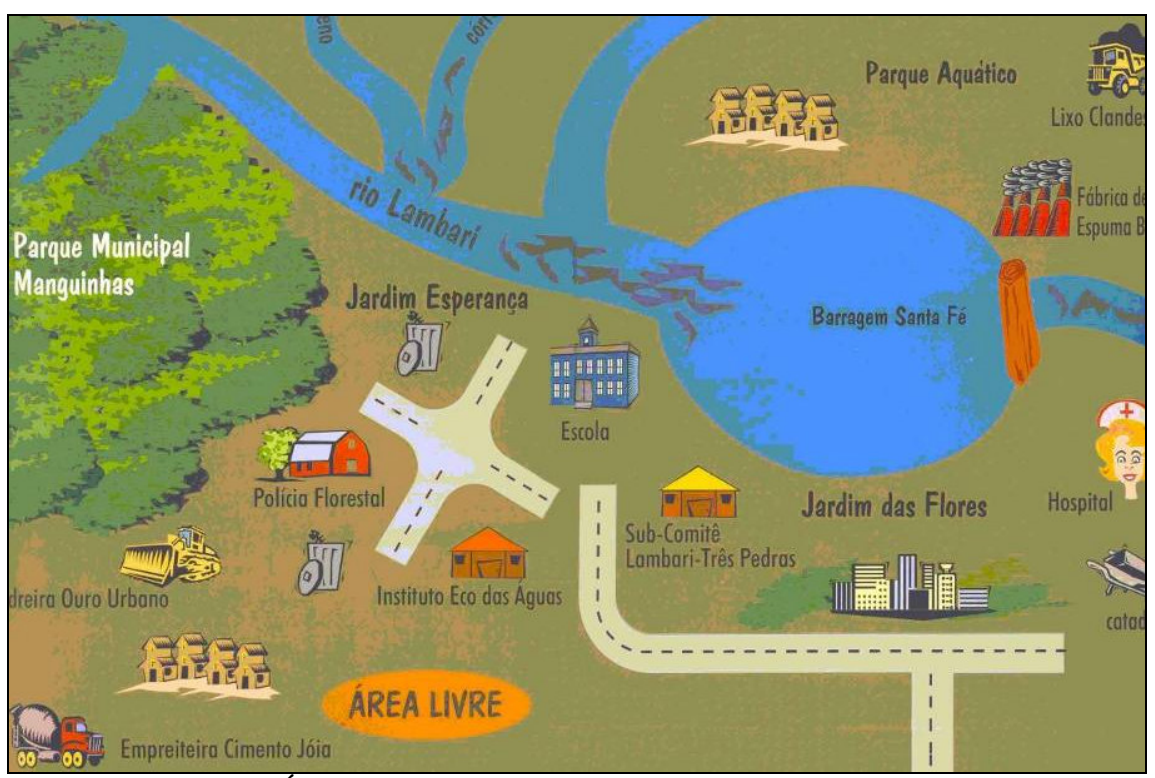

Fonte: Desafio das Águas, Instituto Ecoar para a Cidadania, Junqueira $e t$ al.(1999) São Paulo, Brasil

Descrição geral: O jogo apresenta várias situações de conflito sobre questões urbanas como lixo e esgoto nos córregos, enchentes, participação da população, em que os personagens devem discutir em busca de soluções coletivas.

Dinâmica de jogo: O grupo escolhe um coordenador para o jogo, que será o mediador da sessão; este sorteia uma carta de situação e apresenta os personagens envolvidos. Cada jogador se posiciona em volta do tabuleiro, posiciona-se o peão na região onde a ação se desenrola e a discussão inicia-se com a questão proposta pela carta de situação. A rodada termina quando o grupo finalizar a discussão do assunto ou quando se chegar a um consenso.

Cenário: Sub-bacia do rio 'Lambari”, local caracterizado por vários equipamentos públicos que compõem a cidade: escola, posto de saúde, prefeitura, indústria, loteamentos populares, comitê de bacia, dentre outros. 


\subsubsection{Jogo do "Estatuto da Cidade"(EC)}

Nome: Estatuto da Cidade.

Autor: Instituto Polis (ONG SP) e PUC Campinas, 2002

Objetivos: jogo de papéis desenvolvido para contribuir na difusão e capacitação sobre os instrumentos da Lei federal 10.257 de 2001: Estatuto da Cidade que regulamenta aspectos da gestão urbana.

Público-alvo: técnicos do poder público e movimentos sociais de luta por moradia. O jogo foi difundido através da formação de multiplicadores que atuam na formação de comunidades locais.

Número de jogadores: 6 a 8 jogadores
Figura 8 - Visão parcial do Tabuleiro do Jogo "Estatuto da Cidade" (EC)

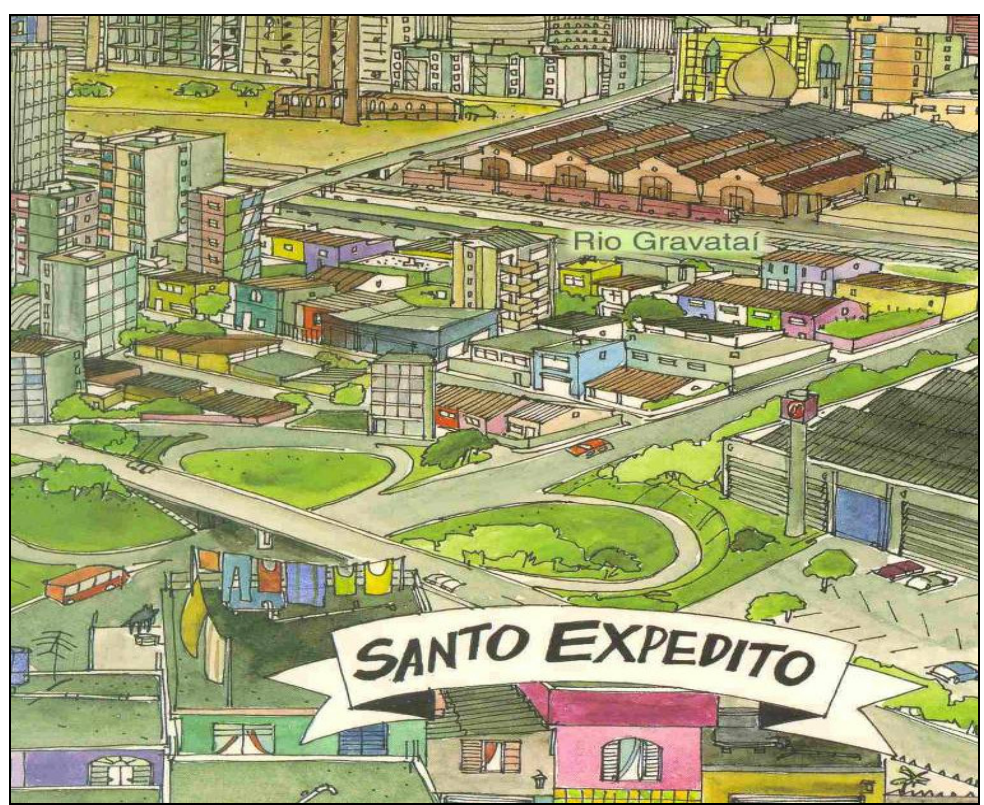

Fonte: extraido de Estatuto da Cidade, The. Instituto Pólis/PUC Campinas, Rolnik, R., Cymbalista, R., Santoro, P. et al (2002). In Rolnik, R. Kit das Cidades. Editora Instituto Pólis, São Paulo, Brasil

Descrição geral: $\mathrm{O}$ jogo é um dos instrumentos de capacitação do Kit das Cidades, composto por vídeo, guia do estatuto, cartilhas, Cd-roms. Esse material teve uma tiragem de 1000 exemplares que foram amplamente distribuídos em nível nacional. Atualmente o Kit das Cidades está na sua segunda edição. O jogo de papéis apresenta situações-problema que os participantes devem resolver utilizando pelo menos um dos instrumentos disponíveis na legislação do Estatuto da Cidade

Dinâmica de jogo: O facilitador do jogo escolhe uma situação-problema descrita no manual do jogo, os papéis são distribuídos aos participantes através das cartas de personagens. O grupo deve então discutir a situação proposta utilizando pelo menos um dos instrumentos do "Estatuto da Cidade" disponíveis. A rodada termina quando a discussão chega a um acordo consensual entre todas as partes.

Cenário: Como o jogo teve ampla distribuição para o Brasil todo, era preciso considerar os diversos tipos de municípios brasileiros. São representadas 3 cidades distintas: uma no litoral: "Tesouro de Areia", uma na zona rural: "Rurópolis"e uma em região metropolitana: 'Santo Expedito". 


\subsubsection{Jogo da “Regularização Fundiária” (REG)}

Nome: "Regularização Fundiária"

Autor: ONG internacional Cohre - Centro pelo

Direito à Moradia Contra Despejos, sediada em Porto

Alegre, RS, 2004

Objetivos: formação de movimentos sociais de luta por moradia nas etapas do processo de regularização fundiária, um dos instrumentos estabelecidos pelo

Estatuto da Cidade (Lei federal 10.257).

Público-alvo: movimentos sociais de luta por moradia e outros movimentos sociais interessados na temática da regularização.

Número de jogadores: 6 a 8 jogadores

Descrição geral: O jogo explicita as etapas do processo de regularização fundiária, em contextos distintos: área pública, favela em área de propriedade privada, loteamento irregular e área de propriedade mista.

Dinâmica de jogo: $\mathrm{O}$ facilitador seleciona uma situação-problema e a partir da proposta os jogadores em grupo devem regularizar as terras em questão utilizando os diversos instrumentos da legislação e interagindo com os atores adequados envolvidos no processo. A rodada termina quando o grupo consegue chegar à regularização fundiária.

Cenário: Vários ambientes representados por fotografias: "Vila do Parque", "Favela Novos Alagados", 'Loteamento Sol Nascente" e "Vila Santa Maria". 


\subsubsection{Jogo da "Construção do Espaço Urbano" (CEU)}

Nome: "Construção do Espaço Urbano"

Autor: Sociedade Cooperativa Ambiens, Curitiba, PR, 2004

Objetivos: explicitar a dinâmica de produção do espaço urbano no que se refere à valorização dos terrenos, zoneamento e ocupação de áreas protegidas pela população de baixa renda. Sensibilizar os técnicos para a problemática em questão.

Público-alvo: técnicos da secretaria do planejamento e habitação e comunidades de baixa renda residentes na periferia.

Número de jogadores: 6 jogadores
Figura 9 - Visão Parcial do Tabuleiro do Jogo 'Construção do Espaço Urbano"(CEU)

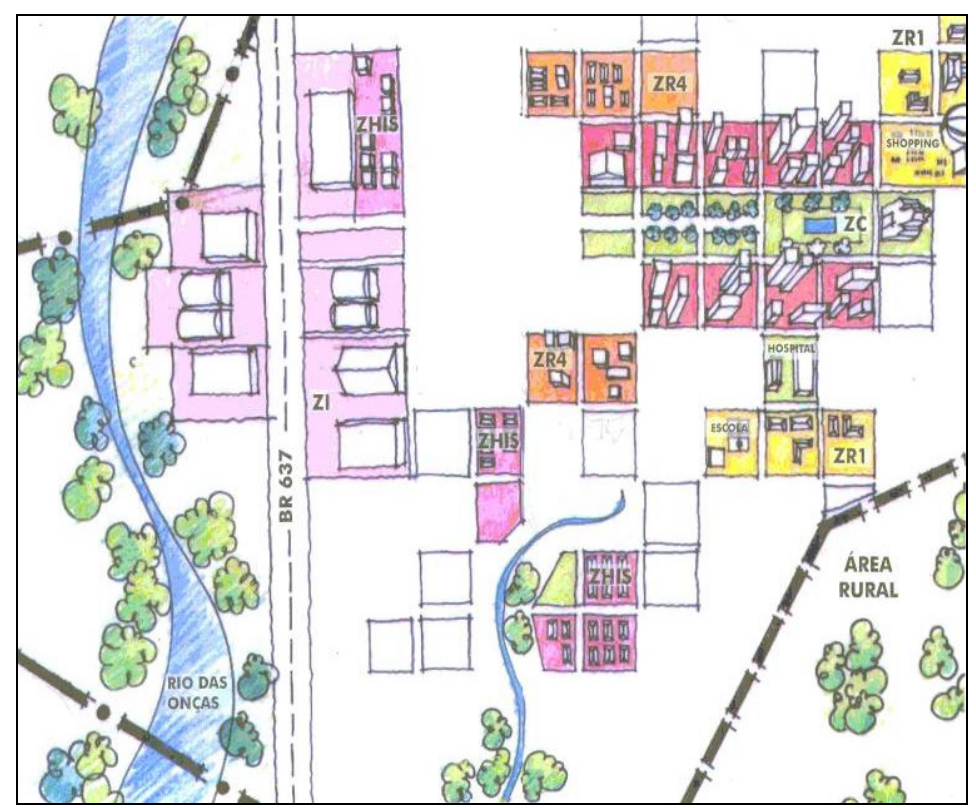

Fonte: Construção do Espaço Urbano, o jogo. .Ambiens, Sociedade Cooperativa, Albuquerque, A. et al (2004) Curitiba, PR, Brasil

Descrição geral: Na situação-problema são apresentados personagens empregados de um incorporador da cidade que desejam adquirir sua casa própria, depois de um ano de trabalho eles constatam, através do salário recebido onde poderão comprar sua moradia, de acordo com o zoneamento da cidade e valor agregado.

Dinâmica de jogo: As rodadas correspondem a um ano de tempo real, no início o incorporador seleciona os empregados e começa a construção do empreendimento. Os jogadores escolhem o local desejado para morar - "casa dos sonhos" e localizam -na no mapa da cidade. Depois de um ano (uma rodada de jogo) eles recebem os salários relativos ao cargo que desempenham e constatam onde podem adquirir a sua moradia - "casa real". Ao fim do jogo há uma discussão sobre a impossibilidade de adquirir as casas do sonho que envolve questões de zoneamento e valorização dos terrenos.

Cenário: - Uma planta/mapa de uma cidade imaginária com o respectivo zoneamento. 


\subsubsection{Jogo dos "Mananciais" (MAN)}

Nome: Jogo dos Mananciais

Autor: Projeto Negowat SP, 2004

Objetivos: explicitar a problemática da gestão integrada dos recursos hídricos e o uso e ocupação do solo em bacias periurbanas numa região metropolitana. $\mathrm{O}$ Jogo dos Mananciais é um jogo acadêmico com foco na modelagem de acompanhamento (ComMod).

Público-alvo: estudantes de nível superior, técnicos ligados à gestão dos recursos hídricos.

Número de jogadores: 9 a 15 jogadores
Figura 10 - Visão Parcial do Tabuleiro do Jogo dos 'Manancia is”(MAN)

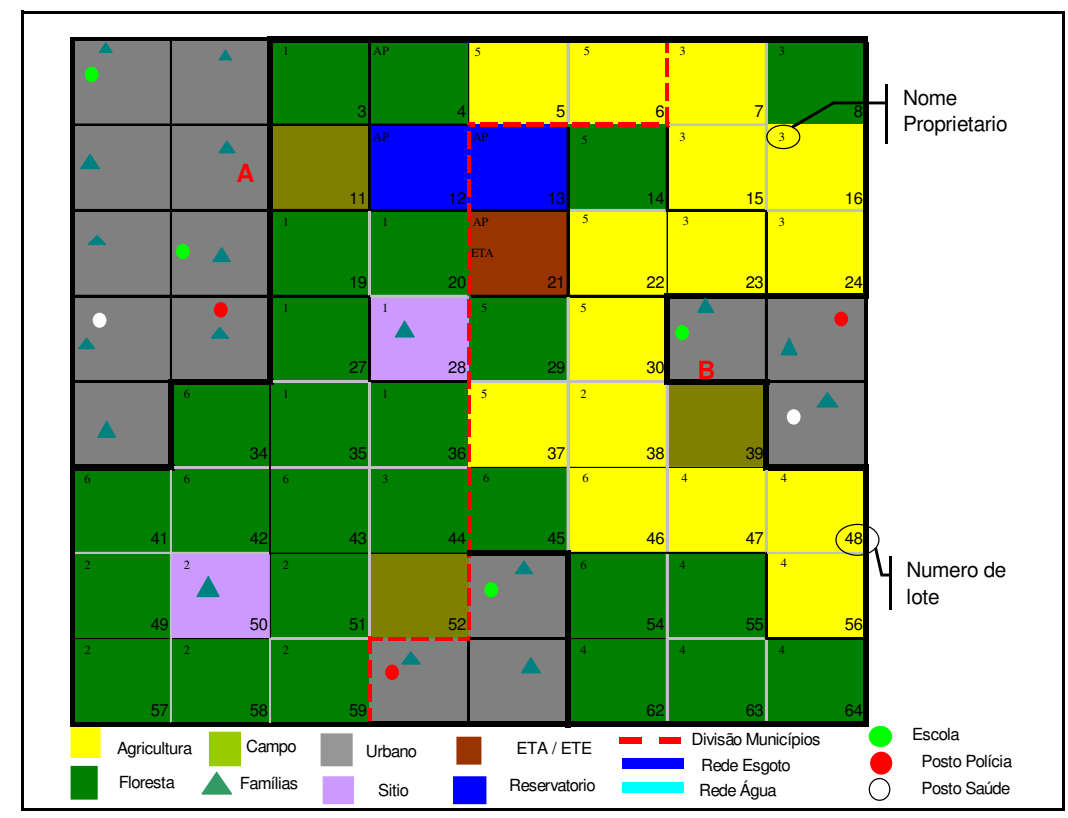

Fonte: JogoMan o jogo, Projeto Negowat (Negotiation on Water Resources), Ducrot, R. et al (2004) CIRAD, Procam/ USP, Instituto Polis entre outras instituições (2004), São Paulo, Brasil

Descrição geral: O jogo apresenta uma situação-problema de poluição nos reservatórios devido à crescente urbanização e simula uma reunião do comitê de bacia para a discussão do problema em questão; desta situação participam os prefeitos, empresa de tratamento de água e esgoto, proprietários de terra, Secretaria do meio ambiente e movimentos sociais de luta por moradia.

Dinâmica de jogo: Os jogadores recebem instruções sobre os papéis e funções que desempenham juntamente com o mapa de localização de suas parcelas ou terrenos. Em seguida devem tomar decisões relativas à alteração do uso do solo em suas parcelas ou compra e venda dos lotes. Os jogadores que representam a Cia de Água e a Prefeitura podem ainda investir em redes de água e esgoto e equipamentos públicos. O jogo é dividido em fases: (1) tomadas de decisão individuais, em que cada jogador implementa sua estratégia (2) interações entre os jogadores como compra e venda de terrenos e (3) uma tomada de decisão coletiva durante a simulação de uma reunião do "Comitê de Bacia". No final do jogo há um momento de avaliação coletiva ou "debriefing".

Cenário: Um mapa modelizado (abstrato) com 64 parcelas de 1 ha cada localizadas numa bacia peri-urbana, numa área de manancial. 


\section{EXPERIÊNCIAS BRASILEIRAS DE JOGOS DE PAPÉIS NA ÁREA AMBIENTAL E URBANA: ELEMENTOS PARA PENSAR OS LIMITES E POTENCIALIDADES DESTA METODOLOGIA EM PROJETOS DE EDUCAÇÃO AMBIENTAL}

A apresentação dos resultados e discussão dos mesmos foi dividida em duas partes que correspondem a dois capítulos distintos. Neste capítulo apresentamos os resultados do levantamento e comparação de alguns jogos de papéis brasileiros sobre a temática da gestão ambiental e urbana desenvolvidos em projetos de educação popular e ambiental. No próximo capítulo, destacamos o processo de elaboração do Jogo dos Mananciais, apresentando suas principais diferenças e similaridades em relação aos jogos tradicionais citados anteriormente, aprofundando a análise.

Desta forma, buscamos na discussão responder às questões centrais da pesquisa:

Quais as potencialidades e limites dos jogos de papéis numa proposta de Educação Ambiental crítica?

Quais as contribuiçõos dos jogos de papéis com simulação de cenários, desenvolvidos a partir do enfoque da modelagem de acompanhamento, para a EA? O que ainda precisa ser aprimorado para que jogos de papéis ComMod participem como instrumentos didáticos de processos de Educação Ambiental?

\subsection{A UTILIZAÇÃo DE JOGOS DE PAPÉIS NA GESTÃo DOS RECURSOS NATURAIS}

Inicialmente é importante situar o leitor sobre as funções dos jogos de papéis, no que concerne aos seus objetivos num processo de gestão ambiental. De acordo com a literatura, os jogos de papéis podem ser utilizados para diversas funções, o que denominamos usos distintos, encontramos três grandes usos distintos para os jogos de papéis, a saber (MAYER; DEJONG, 2004):

1. Formação 
O uso do jogo de papéis para capacitação numa perspectiva educativa pode ter públicos e objetivos diversos. Uma comunidade acadêmica em técnicas de negociação, comunidades locais em projetos de formação e educação popular, técnicos de políticas públicas para uma percepção mais realista dos problemas sócio-ambientais, todos esses podem ser considerados público-alvo (JUNQUEIRA, 1999).

Nesta área existem muitas experiências acadêmicas como o Programa de Negociação de Harvard (Program on Negotiation at Harvard Law School - PON) um programa universitário interdisciplinar da Faculdade de Direito de Harvard. O programa desenvolve cursos de formação em resolução e negociação de conflitos e para tanto utiliza muitos jogos de papéis como metodologia. Como exemplo destacamos o jogo Radwaste, desenvolvido pelo PON, cujo objetivo concentra-se na definição de um local para a construção de um aterro sanitário para depósito de resíduos radioativos de baixa periculosidade. Neste contexto, são convidados a discutir os representantes dos municípios potenciais para sediar o empreendimento, os ambientalistas, o governo e as indústrias geradoras de tais resíduos. As informações confidenciais distribuídas aos jogadores determinam os interesses de cada jogador que não estão explícitos, há uma tabela para contagem dos pontos que determina os resultados da negociação, indicando também o tipo de acordo realizado.

Aqui no Brasil alguns órgãos públicos também desenvolvem jogos de papéis em seus programas de formação de técnicos e gestores públicos. Como exemplo, no estado de São Paulo, destacamos a FUNDAP (Fundação do Desenvolvimento Administrativo). Os jogos utilizados em formação de gestão e administração pública são considerados 'jogos de governança" desenvolvidos de acordo com a temática que se pretende discutir e com o objetivo de explicitar os diversos interesses presentes em uma negociação de conflitos.

A maioria das experiências brasileiras relatadas situa-se no campo da formação, todos os jogos selecionados nesta análise possuem a formação como foco principal, são eles: Desafio das Águas (DA), Jogo do Estatuto da Cidade (EC), Jogo da Construção do Espaço Urbano (CEU), Jogo da Regularização (REG) e Jogo dos Mananciais (MAN). As características destes jogos serão analisadas de forma detalhada ao longo da pesquisa. 


\section{Pesquisa}

O jogo de papéis tem sido utilizado por diversos pesquisadores internacionais como instrumento de investigação sobre as regras sociais de interação entre os atores, bem como sobre as regras de gestão dos recursos naturais em determinada realidade. Os jogos de papéis podem também ser utilizados para a validação de um modelo de difícil compreensão. Mais do que um grupo focal ou uma tradicional dinâmica de grupo, esta metodologia permite, a partir da vivência de papéis, considerar as diversas percepções sobre um mesmo problema ou conflito sócio-ambiental. Neste sentido, o jogo de papéis pode contribuir para uma representação compartilhada da realidade, na medida que explicita e traz à tona os vários pontos de vista e interesses diversos dos atores sociais envolvidos num determinado conflito (BOISSAU; CASTELLA, 2003; ETIENNE, 2003).

Como exemplos de jogos de papéis utilizados em projetos de pesquisa destacam-se o 'Njoobaari ilnoowo" ou "Jogo do Senegal", um projeto do CIRAD desenvolvido com agricultores do vale do rio Senegal, na África; e a metodologia "Samba-Week" que combina jogo de papéis, entrevistas e modelagem multi-agente num processo elaborado para a análise do sistema de uso do solo e gestão local dos recursos naturais no Vietnã. (BOISSAU; CASTELLA, 2003; BARRETEAU; BOUSQUET; ATTONATY, 2001; DARÉ, 2005). No Brasil, a utilização de jogos de papéis como ferramenta de investigação e pesquisa ainda se situa num campo restrito, pouco explorado e documentado atualmente.

\section{Intervenção}

Função do jogo de papéis quando este é inserido no próprio processo de negociação e de decisão na realidade local, neste caso o instrumento pode ser utilizado para facilitar a comunicação entre os atores envolvidos, explicitar certos conceitos técnicos de difícil assimilação e ajudar na negociação e no processo de decisão de questões polêmicas. Este tipo de uso para os jogos de papéis ainda é pouco relatado, tanto no Brasil, quanto no exterior. Como exemplo, destacamos a experiência "Self-Cormas", proposta de um modelo de simulação acoplado a jogo de papéis desenvolvida com o objetivo de 
compartilhar conhecimento e aumentar o poder de atuação de grupos de agricultores e pecuaristas na região de Saint-Louis no Senegal. Vale destacar que esta proposta foi desenvolvida de forma participativa, integrando os atores locais na concepção do jogo e definição das regras (D’AQUINO, 2003).

Além dos usos ou funções dos jogos de papéis, foram identificados também três espaços de discussão onde estas experiências puderam ser encontradas: (1) fórum definido, (2) atores difusos em relação ao fórum definido e (3) atores difusos na ausência de um fórum definido, detalhados a seguir:

\section{Fórum definido}

No caso brasileiro seria o Comitê ou Sub-Comitê de bacia hidrográfica na área da gestão dos recursos hídricos, conselhos de participação popular nas diversas áreas e os órgãos técnicos do governo nos diversos níveis, como as secretarias de planejamento do Estado ou do município, na área urbanística;

\section{Atores difusos em relação ao fórum definido}

No caso de um trabalho com associações comunitárias, movimentos sociais e membros da sociedade civil organizada que poderiam ter acesso aos fóruns definidos, que participam de outros fóruns, mas não necessariamente estão representados no Comitê de bacia ou nos respectivos conselhos;

\section{Atores difusos na ausência de um fórum definido}

Quando existem os conflitos sócio-ambientais, mas não existe um fórum institucionalizado para a resolução e negociação dos mesmos, essa situação ocorre em alguns países como a Bolívia, que não possui em sua estrutura legislativa um sistema de gerenciamento de recursos hídricos descentralizado e reconhecido legalmente.

Para situar os jogos de papéis coletados no levantamento bibliográfico, procedemos ao cruzamento da categoria "Usos ou Funções" com a categoria "Espaços de discussão" esclarecendo assim onde estão inseridas estas propostas. 
Há ainda um outro espaço de discussão específico ao Jogo dos Mananciais (MAN), que foi direcionado ao público estudante em nível de graduação e pós-graduação.

Quadro 4 - Localização dos Jogos: Espaços de Discussão versus Usos ou Funções

\begin{tabular}{|c|c|c|c|c|}
\hline & \multicolumn{3}{|c|}{ Usos ou Funções } \\
\hline & & Pesquisa & Formação & Intervenção \\
\hline \multirow{4}{*}{ 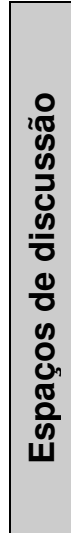 } & Fórum definido & & $\begin{array}{c}\text { Jogo do Estatuto da Cidade (EC) } \\
\text { Jogo da Construção do Espaço urbano (CEU) } \\
\text { Radwaste- PON - EUA }\end{array}$ & \\
\hline & $\begin{array}{l}\text { Atores difusos } \\
\text { com relação ao } \\
\text { fórum definido }\end{array}$ & & $\begin{array}{c}\text { Desafio das Águas (DA) } \\
\text { Jogo da regularização fundiária (REG) }\end{array}$ & $\begin{array}{l}\text { Self-Cormas, } \\
\text { Cirad Senegal }\end{array}$ \\
\hline & $\begin{array}{l}\text { Atores difusos } \\
\text { na ausência de } \\
\text { um fórum } \\
\text { 4definido }\end{array}$ & $\begin{array}{c}\text { Samba- Week, } \\
\text { Boissau, Vietnã } \\
\text { Njoobaari ilnoowo } \\
\text { Jogo do Senegal - } \\
\text { Cirad } \\
\end{array}$ & & \\
\hline & Estudantes & & Jogo dos Mananciais (MAN) & \\
\hline
\end{tabular}

Fonte: elaborado pela autora

\subsection{RESULTADOS E DISCUSSÃO DO LEVANTAMENTO E COMPARAÇÃO DE ALGUMAS EXPERIÊNCIAS BRASILEIRAS QUE UTILIZAM JOGOS DE PAPÉIS NA ÁREA AMBIENTAL E URBANA;}

As experiências destacadas em negrito no quadro correspondem aos jogos selecionados para a comparação e análise. Trata-se de experiências de formação quanto à função e variam em relação ao público-alvo, dois jogos têm o público-alvo como um fórum definido (EC) e (CEU) e os outros três destinam-se a atores difusos com relação ao fórum definido (DA), (REG) ou público de estudantes (MAN).

A nossa análise baseia-se na comparação de quatro jogos de papéis desenvolvidos para a capacitação de atores locais ou de técnicos do poder público sobre aspectos da gestão ambiental, planejamento urbano e assuntos específicos relativos a novos instrumentos de legislação ainda de difícil compreensão para grande parte da população. Os jogos de papéis em questão foram considerados como ferramentas de formação pelos autores. $\mathrm{Na}$ nossa análise não é possível explorar os impactos ou outro tipo de avaliação sobre a eficiência das ferramentas, para isso seria necessário um tempo maior de pesquisa e uma avaliação local aprofundada com o público-alvo de cada experiência. Trata-se mais de um levantamento de experiências de formação utilizando jogos de papéis a fim de 
comparar uma amostra do que está sendo desenvolvido no Brasil com as perspectivas da proposta ComMod, em nível internacional.

\subsubsection{Características em comum das experiências selecionadas}

Os jogos de papéis selecionados apresentam algumas características em comum que nos permitiram agrupá-los nesta análise, a saber: (1) a problemática da complexidade da gestão urbana e da gestão ambiental, (2) o propósito de formação e capacitação como função principal da ferramenta e (3) o público a que se destina, composto por atores comunitários ou representantes de comunidades locais ou por técnicos de alguns setores do governo que se relacionam com as comunidades.

\section{- Quatro jogos que abordam a complexidade da gestão ambiental urbana}

Desses quatro jogos, um apresenta o foco sobre a gestão dos recursos hídricos em subbacias de uma região metropolitana (DA), dois (EC e REG) apresentam os instrumentos do Estatuto da Cidade, lei federal 10.257/2001 que exige a elaboração de Plano Diretor

para todos os municípios com mais de 20.000 habitantes, regulamentando assim o uso e a ocupação do solo na cidade para garantir a função social da mesma. O jogo (CEU) discute a questão do valor agregado aos terrenos no espaço urbano ressaltando a importância de se desenvolver uma visão compartilhada sobre o problema entre os diversos atores envolvidos.

\section{- Quatro jogos de papéis com proposta de formação}

Os jogos (EC) e (REG) foram desenvolvidos com um objetivo específico de ilustrar um conjunto de conceitos de difícil entendimento para técnicos e para a população em geral sobre as possibilidades de uma nova legislação para a gestão urbana (Estatuto da Cidade, Lei Federal 10.257/2001). Os outros jogos (DA) e (CEU) apresentam como objetivo a discussão de conflitos sócio-ambientais, demonstrando a existência dos diversos interesses e, conseqüentemente a importância do processo de negociação. Vale destacar que os cinco jogos são utilizados como materiais didáticos em processos de Educação 
Popular, em âmbito mais amplo, e não apenas em projetos específicos de Educação Ambiental. O Jogo do Estatuto da Cidade (EC) é utilizado no final de um curso de dois dias sobre a legislação referente ao Estatuto da Cidade. Neste contexto, o jogo é uma forma de verificar o aprendizado e a apropriação dos novos conceitos explicitados durante o curso, como uma síntese de conteúdos. O jogo Desafio das Águas (DA) é parte de uma metodologia de discussão da gestão dos recursos hídricos em áreas peri-urbanas. O jogo da Regularização (REG) foi desenvolvido para ser utilizado num curso específico sobre as etapas do processo de regularização fundiária e direito à moradia.

\section{- A diversidade do público-alvo}

Os jogos foram desenvolvidos para públicos diversos: técnicos do poder público em várias instâncias; representantes de conselhos ou membros dos comitês de bacia, no caso da gestão dos recursos hídricos; lideranças comunitárias de movimentos sociais ou estudantes. Os jogos selecionados variam também na escala de distribuição e aplicação: o jogo (CEU) foi restrito ao treinamento de técnicos locais do município de Londrina, por outro lado, os jogos (DA) e (EC) foram já amplamente distribuídos e utilizados em larga escala, o Desafio das Águas (DA) em São Paulo e o Estatuto da Cidade (EC) no Brasil todo.

\section{- Quatro jogos cooperativos}

Todas as experiências correspondem a jogos de papéis do tipo cooperativos, ao contrário dos tradicionais jogos competitivos, nestes a cooperação é o modo de interação entre os jogadores, uma vez que para a realização das tarefas do jogo é necessário estabelecer acordos. A definição de jogo cooperativo utilizada é a seguinte: "O jogo cooperativo consiste em jogos e atividades em que os participantes jogam juntos, ao invés de contra os outros (....) são jogos onde o esforço cooperativo é necessário para se atingir um objetivo comum e não para fins mutuamente exclusivos. Através deste tipo de jogo aprendemos a trabalhar em grupo, confiança e coesão grupal. A ênfase está na participação, na partilha, na aceitação de todos os jogadores e no reconhecimento que todo jogador é importante" ( BROTTO, 2001). 


\subsubsection{Os critérios de comparação dos jogos}

Conforme previamente mencionado, a sessão de jogo foi considerada como uma dinâmica de grupo durante o processo educativo e a partir deste princípio e de referências teóricas pautadas na análise de experiências semelhantes, selecionamos os seguintes critérios de análise: (1) contexto de utilização do jogo; (2) o "ambiente" de jogo; (3) o tipo de tarefas solicitadas aos jogadores; (4) as características dos papéis/personagens e (5) as formas de avaliação, conforme detalhado no quadro seguinte.

Quadro 5 - Critérios selecionados para a análise dos jogos de papéis estudados

\begin{tabular}{|c|c|}
\hline \multicolumn{2}{|r|}{ Critérios para análise dos jogos de papéis selecionados } \\
\hline \multirow{2}{*}{1} & Contexto de utilização do jogo durante o processo educativo \\
\hline & (no início, durante o processo ou no final) \\
\hline \multirow{3}{*}{2} & O ambiente do jogo (cenário/espaço e tempo) \\
\hline & 2.1. Cenário (mapas, fotografias, tabuleiro desenhado) \\
\hline & 2.2. Tempo (dividido em rodadas ou não, ilustração do diagrama da sessão \\
\hline \multirow[b]{2}{*}{3} & Tarefas solicitadas aos jogadores \\
\hline & $\begin{array}{l}\text { (tipos de tarefas: intelectuais ou comportamentais, seqüenciais ou } \\
\text { independentes) }\end{array}$ \\
\hline \multirow{2}{*}{4} & Características dos papéis/personagens do jogo \\
\hline & (tipos de características: pessoais ou profissionais) \\
\hline 5 & Formas de avaliação \\
\hline
\end{tabular}

Fonte: elaborado pela autora

De acordo com o quadro acima, detalhamos o que foi analisado em cada um dos critérios apresentados:

(1) Contexto de utilização do jogo durante o processo educativo - A maioria desses jogos de papéis estão inseridos em processos de treinamento e formação mais amplos . Portanto, estes jogos podem ser utilizados no início do processo, para facilitar a comunicação entre os participantes e promover um clima mais favorável às discussões através do fator lúdico; podem aparecer em algum momento ao longo do processo de formação ou então são inseridos no final de um curso ou treinamento para promover uma síntese e verificar o entendimento dos conteúdos abordados durante todo o curso. O 
contexto de utilização do jogo é importante para entender o papel do jogo no processo educativo.

(2) O ambiente do jogo (cenário/espaço e tempo) - Um fator essencial presente nos jogos de papéis é a representação de um cenário virtual que corresponde a uma parte da realidade que se pretende explorar, pode ser uma cidade imaginária ou uma região. Para tanto, o jogo pressupõe alterações no espaço e no tempo real. Neste critério de análise exploramos o tipo de suporte utilizado para a representação do território e sua representação gráfica (tipos de ilustrações, fotografias, mapas, tabuleiro de jogo) e a contagem do tempo (em rodadas ou não), sendo que uma rodada pode corresponder a um ano de tempo real, por exemplo.

(3) Tarefas solicitadas aos jogadores - As tarefas do jogo ou da dinâmica de grupo numa reunião são critérios de análise apontados pelos diversos autores, uma vez que correspondem a uma seqüência de ações que caracterizam o jogo em si (McGrath,1984 apud TUNG; TURBAN, 1998; FJERMESTAD,1997). Inicialmente realizamos uma descrição de todas as tarefas solicitadas em seguida procedemos a uma classificação das mesmas. As tarefas foram classificadas em: (1) intelectuais - tarefas que demandam uma decisão: este tipo de tarefas foi identificado por verbos como: debater, discutir, negociar conflitos, descritos no manual de instruções dos jogos- e tarefas comportamentais ou físicas - as que demandam uma ação, identificadas por ações de preenchimento de fichas, posicionamento de peças no tabuleiro ou deslocamento na sala de jogo; (2) individuais as que dependem apenas de um jogador e coletivas - as que dependem de dois ou mais jogadores; (3) seqüenciais, recíprocas ou independentes, ilustrando o tipo de dependência existente entre as tarefas propostas e a ordem de realização das tarefas durante o jogo.

(4) Características dos papéis/personagens do jogo - Os papéis são características essenciais dos jogos de papéis. Como o próprio nome indica, é a possibilidade de incorporação de personagens que diferencia este tipo de jogo dos demais. Nos jogos analisados diferenciamos três tipos de caracterização dos papéis: (1) os que descrevem cargos ou funções, (2) os que se concentram nas atribuições e características dos personagens e (3) os que definem apenas as profissões dos personagens. Dentre estes, há 
aqueles papéis que chamamos "psicologizados" c om características pessoais dos personagens contidas nas informações confidenciais e outros que são mais neutros, sem indicações da vida pessoal dos personagens.

(5) Formas de Avaliação - A avaliação é um fator essencial em qualquer experiência educativa de formação, aqui analisamos o público-alvo a quem se destina a avaliação, os materiais utilizados e os assuntos abordados.

\subsubsection{Os resultados da comparação dos jogos}

\section{- Contexto de utilização dos jogos}

Quadro 6 - Contexto de utilização dos jogos de papéis estudados

\begin{tabular}{|c|c|c|c|}
\hline & \multicolumn{3}{|c|}{ Contexto de utilização } \\
\hline & Início & Durante o processo & Final do curso \\
\hline 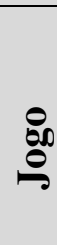 & $\begin{array}{l}\text { (CEU) - o jogo foi utilizado } \\
\text { para sensibilizar os técnicos } \\
\text { sobre a questão da ocupação } \\
\text { irregular em áreas protegidas } \\
\text { nas cidades }\end{array}$ & $\begin{array}{l}\text { (DA) - o jogo foi concebido a } \\
\text { partir das situações-problema } \\
\text { identificadas na fase de diagnóstico }\end{array}$ & $\begin{array}{l}\text { (EC) e (REG) são } \\
\text { utilizados no final de um } \\
\text { curso sobre gestão urbana } \\
\text { e direito à moradia }\end{array}$ \\
\hline
\end{tabular}

Fonte: elaborado pela autora.

Conforme descrito no quadro, notamos diversas possibilidades de uso dos jogos de papéis em diversos contextos. Os jogos (EC) e (REG) são utilizados no final de um curso sobre os instrumentos do "Estatuto da Cidade" e "Direito à moradia". Os cursos têm a duração de 12 e 8 horas respectivamente. (DA) é utilizado durante um processo de Educação Ambiental que compreendia uma fase de diagnóstico local, o jogo e um plano de ação, o que permitiu explicitar os conflitos e os atores importantes no processo. Foi uma maneira diferente e criativa de trazer aos participantes do projeto os dados que haviam sido coletados no diagnóstico. O jogo (CEU) é usado no início de um curso para uma primeira sensibilização dos técnicos da área de planejamento sobre a questão da ocupação irregular em áreas protegidas na cidade de Londrina. PR. Ao ser utilizado no ínicio do processo, o jogo de papéis parece ser um mecanismo de integração dos participantes e entendimento do assunto. Ao final de um curso, o jogo pode ser uma forma de sintetizar e discutir conteúdos abordados ao longo do processo. 


\section{- O ambiente de jogo (cenário, espaço e tempo)}

Nos RPGs mais "clássicos ou tradicionais" (como Dungeons \& Dragons), o jogo acontece num ambiente virtual, num tempo de um pasado remoto ou de um futuro distante, apoiado num mapa também imaginário. Nos RPGs educativos, como os que selecionamos neste estudo, o espaço ou cenário do jogo geralmente remete a uma cidade virtual que apresenta semelhanças com a realidade. Os jogos aqui estudados utilizam diversos suportes para descrever esta paisagem virtual que se refere a uma realidade local bastante próxima. O território ou cenário do jogo pode então ser representado por uma fotografia aérea, um tabuleiro com desenhos, uma planta com o zoneamento tradicional de uma cidade, como podemos visualizar no quadro abaixo.

Quadro 7 - Os diferentes cenários e funções do suporte visual nos cinco jogos estudados

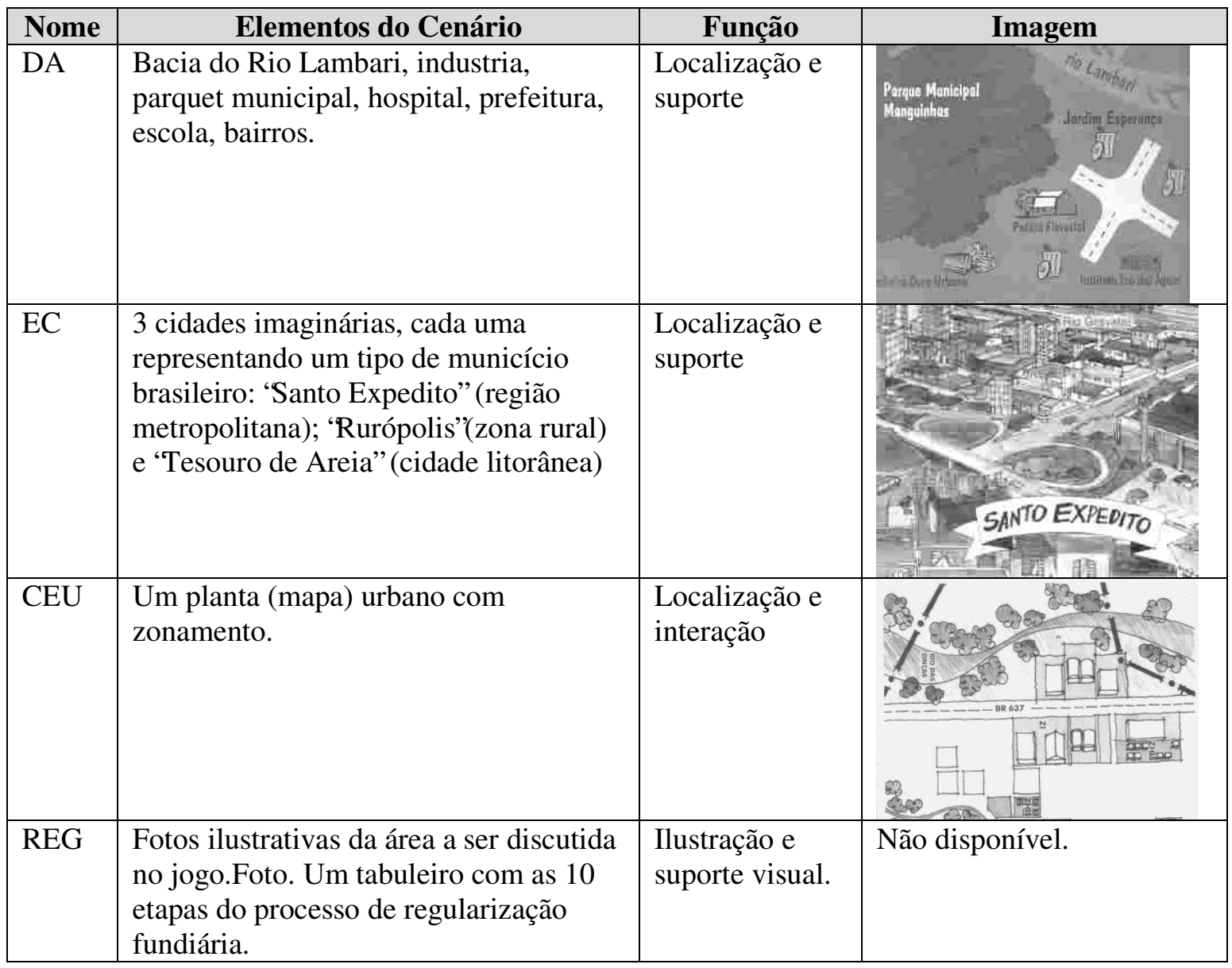

Fonte: elaborado pela autora. 
No tabuleiro do jogo (DA) estão representados os vários ambientes da região: o rio 'Lambari'que atravessa a cidade, a barragem, os córregos, o Parque Municipal, as fábricas, a prefeitura, hospital, escola. As situações do jogo ocorrem em uma determinada região do cenário do jogo, para isso os jogadores têm o tabuleiro para localizarem onde ocorre a situação.

O Jogo do Estatuto da Cidade (EC) apresenta 3 cenários distintos, que correspondem às cidades imaginárias do jogo: uma para cada tipo de município brasileiro: um no litoral Tesouro de Areia, outra no interior - Rurópolis, e outra em área urbana, metropolitana Santo Expedito, mostramos as diferenças entre um cenário mais próximo à realidade (município de "Santo Expedito", do Jogo do Estatuto da Cidade) . Um dos jogos, o Jogo da Construção do Espaço Urbano (CEU) utiliza um mapa impresso do tipo de uma planta da cidade com a delimitação do zoneamento urbano.

(EC) foi um jogo desenvolvido para todo o Brasil e portanto apresenta o desafio de representar questões pertinentes a realidades distintas que compreendam um pouco da diversidade dos municípios brasileiros. Desta forma, foram desenvolvidos três tabuleiros de jogo diferentes, representando possibilidades distintas (uma metrópole, uma cidade litorânea e uma cidade do interior, zona rural). Os tabuleiros evidenciam as principais características de cada tipo de município através de desenhos.

Os cenários de jogo também podem apresentar diversas funções. Nos jogos (DA) e (EC), sua principal função é ilustrar a situação-problema e auxiliar na integração dos jogadores. Já no jogo (CEU) o tabuleiro é o suporte para as ações dos jogadores, que vão localizar as suas casas, as de "sonho" e as "reais ou possíveis", neste caso não é apenas um elemento de ilustração, mas também de interação.

\section{- A organização do tempo de jogo}

A organização do tempo de jogo é também diferente do tempo real, geralmente o jogo é dividido em rodadas, uma rodada de jogo pode representar um ano ou um tempo determinado. 
A divisão de rodadas no jogo (CEU) demonstra uma passagem de tempo e em alguns casos a simulação permite avaliar o impacto das ações de cada um dos jogadores no ambiente como um todo, a presença de mais de uma rodada permite que as ações sejam implementadas. No jogo (CEU) a rodada tem a duração de aproximadamente 30 minutos. Nos outros jogos (DA), (EC) e (REG), a existência de uma grande rodada, ou de um tempo contínuo de jogo, vai possibilitar um tempo maior de discussão, mas os impactos gerais de cada uma das ações ficam dispersos e menos visíveis, as ações não são implementadas efetivamente no ambiente. O tempo de duração de jogo, neste caso pode variar muito em função do grupo. O quadro abaixo sintetiza as informações referentes ao tempo nos diversos jogos.

Quadro 8 - As diferentes formas de organização do tempo de jogo

\begin{tabular}{|c|l|c|}
\hline Jogo & \multicolumn{1}{|c|}{ Organização do Tempo } & Duração da Sessão (em horas) \\
\hline DA & Contínuo (não há divisão em rodadas) & 4 \\
\hline EC & Contínuo (não há divisão em rodadas) & 1 \\
\hline REG & Contínuo (não há divisão em rodadas) & 2 \\
\hline CEU & 2 Rodadas (1 rodada= 1 ano) & 1 \\
\hline
\end{tabular}

Fonte: elaborado pela autora.

\section{- Tarefas solicitadas aos jogadores}

A sequência de ações dos jogadores e tarefas de cada jogo de papéis selecionado estão representadas nos "diagramas de sessão". Estes diagramas explicitam as i nterações entre os jogadores e ilustram a dinâmica de uma sessão de jogo. As tarefas individuais foram diferenciadas das tarefas coletivas ou que requerem algum tipo de interação entre os jogadores, como as discussões em grupo, por exemplo.

Figura 11 - Legenda dos diagramas

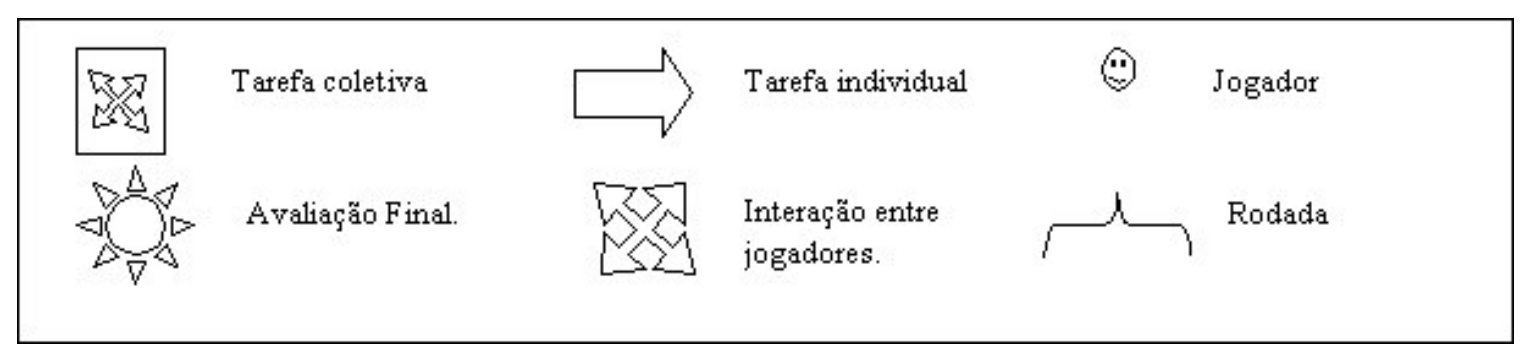

Fonte: elaborado pela autora. 
(DA) e (EC) não apresentam divisão em rodadas, o foco é uma grande discussão coletiva.

Figura 12 - Diagrama da Sessão (DA) e (EC)

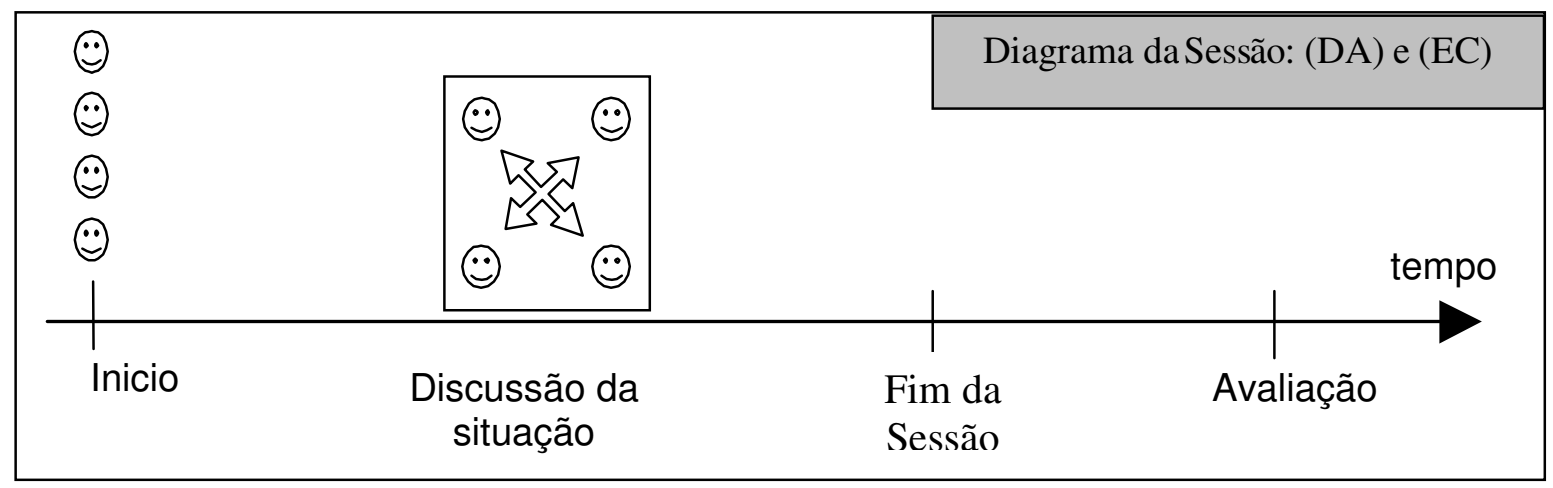

Fonte: elaborado pela autora.

Por outro lado, (CEU) não apresenta nenhuma tarefa coeltiva ou qualquer interação entre os jogadores durante o jogo, cada jogador faz as suas ações individualmente, a única interação ocorre na discussão final (debriefing) sobre o ocorrido durante o jogo. O jogo compreende duas grandes rodadas. Na primeira os jogadores devem localizar no tabuleiro a "casa dos sonhos". Depois de um período de trabalho, os jogadores recebem os seus salários e então podem compras as suas casas. No entanto, a "casa real" que poderão comprar nem sempre corresponde à casa imaginada. As escolhas e a mudança de planos serão os focos da análise final do jogo, na discussão coletiva, nesta fase serão visíveis os padrões e determinantes da urbanização numa cidade.

O jogo (REG) compreende uma série de tarefas coletivas e sequenciais, as quais correspondem às etapas do processo de regularização fundiária previsto no Estatuto da Cidade (lei federal 10.257/2001). Cada etapa é composta por uma discussão coletiva por todos os jogadores. Neste caso, o jogo é composto por uma sequência de tarefas coletivas. 
Figura 13 - Diagrama da Sessão (REG)

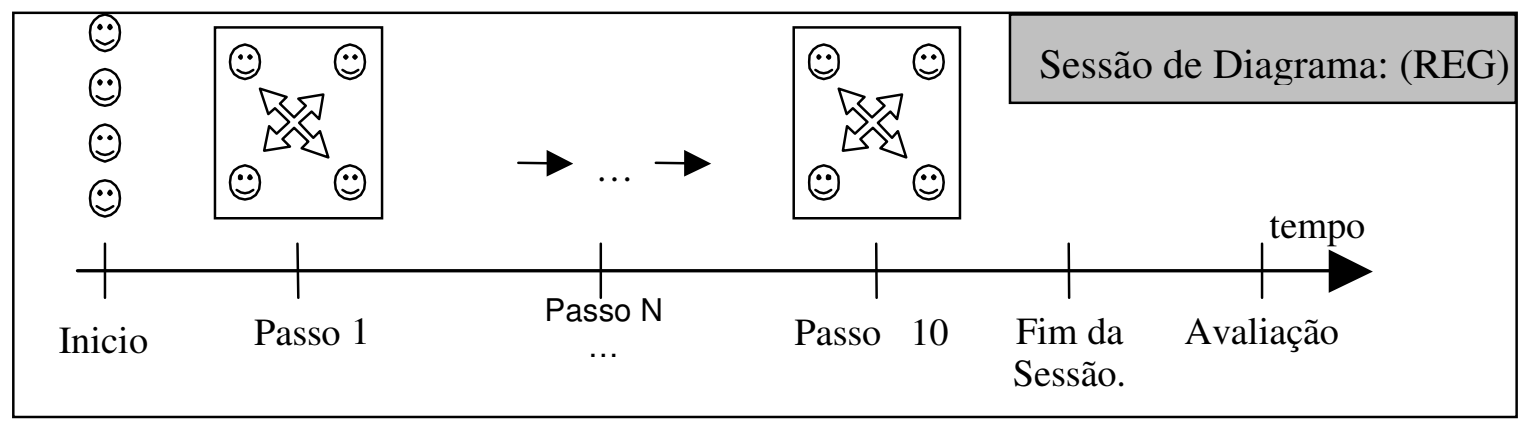

Fonte: elaborado pela autora.

A maioria dos RPGs estudados possibilitam tarefas intelectuais, como discussão, negociação de conflitos, construção de acordos, etc. As tarefas comportamentais, as que requerem algum tipo de deslocamento ou movimento do jogador aparecem apenas no jogo (CEU). (CEU) é também bastante dinâmico, uma vez que ilustra o processo de urbanização visto na realidade, pautado no alto valor da terra na cidade, na especulação imobiliária e em decisões individuais.

Figura 14 - Gráfico dos 4 RPGs de acordo com os tipos de tarefas

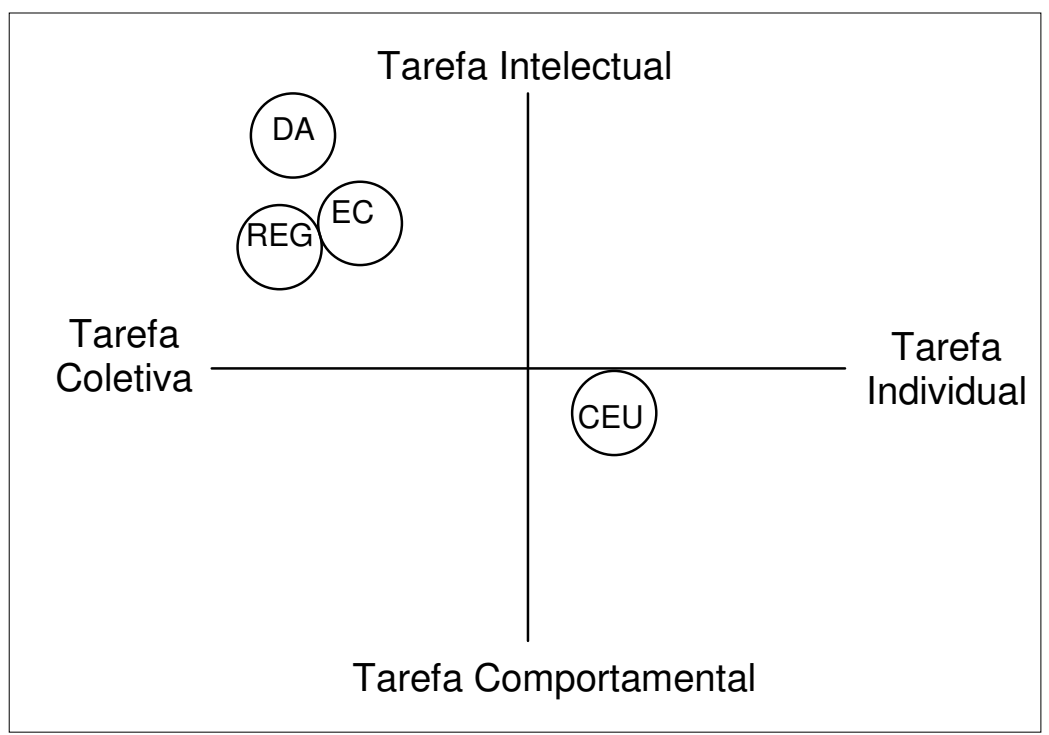

Fonte: elaborado pela autora. 
Todos os jogos apresentam um momento de discussão coletiva, o qual corresponde à principal tarefa em três jogos, (DA) destaca-se por ser composto unicamente por uma discussão coletiva.

No jogo (REG), todos as etapas devem chegar à regularização do terreno e devem ser seguidas por todos os jogadores, reforçando a necessidade de um esforço coletivo.

\section{Características dos papéis/personagens do jogo}

Os papéis representados nos jogos incluem alguns dos diversos atores envolvidos no processo de urbanização. Os jogos (DA) e (EC) apresentam a maior diversidade de papéis, incluindo prefeitos, representantes de bairro, lideranças comunitárias, técnicos do poder público, dentre outros. Os papéis nestes jogos são descritos a partir das características psicológicas do perfil dos personagens. No entanto, nem todos os personagens jogam em todas as sessões, o número de participantes é variável em função da situação-problema escolhida para o jogo, há personagens obrigatórios e opcionais. No jogo (REG) os papéis são descritos por suas ocupações ou profissões, assim como no jogo (CEU).

Neste jogo, a descrição do papel é dada pelos aspectos econômicos (propriedades, gastos e despesas) e pelas funções inerentes ao ator que representa. As informações confidenciais disponíveis aos jogadores nos jogos (DA) e (EC) podem limitar as possibilidades criativas do próprio jogador, embora seja um suporte para iniciar a jogada e criar um ambiente lúdico e descontraído.

Quadro 9 - Tipos de papéis nos jogos analisados

\begin{tabular}{|c|c|c|}
\hline Jogo & Tipo de papéis & $\begin{array}{c}\text { Informações disponíveis na } \\
\text { descrição dos papéis }\end{array}$ \\
\hline $\begin{array}{l}(\mathrm{DA}) \\
(\mathrm{EC})\end{array}$ & $\begin{array}{l}\text { Prefeito, líder comunitário, cidadão, professor, } \\
\text { ambientalista, técnicos em políticas públicas, biólogo, } \\
\text { jornalista, engenheiro, dentre outros }\end{array}$ & $\begin{array}{l}\text { Idade, cargo, local de residência, } \\
\text { história de vida, informações } \\
\text { confidenciais sobre aspectos mais } \\
\text { psicólogicos do personagem }\end{array}$ \\
\hline (CEU) & $\begin{array}{l}\text { Empreendedor, arquiteto, psicólogo, pedreiros e au } \\
\text { xiliares. }\end{array}$ & $\begin{array}{l}\text { Nome da profissão e descrição do } \\
\text { salário (renda) }\end{array}$ \\
\hline
\end{tabular}




\begin{tabular}{|c|l|l|}
\hline (REG) & $\begin{array}{l}\text { Advogado, ONG Direitos Humanos, empresários, } \\
\text { prefeito, técnicos da área de habitação, técnicos da } \\
\text { empresa de água, dentre outros }\end{array}$ & Nome do cargo e descrição \\
\hline
\end{tabular}

Fonte: elaborado pela autora.

\section{- Formas de avaliação}

Todos os quatro jogos apresentam uma avaliação final, embora as formas de avaliação variem bastante nos jogos estudados. Alguns focam na avaliação do processo como um todo, do curso ou do treinamento (EC, REG); enquanto que outros, o foco está mais na análise do jogo (debriefing): (CEU, DA). Nas sessões de jogo que tivemos a oportunidade de participar, a fase de síntese ou avaliação final não foi realizada sistematicamente, devido à falta de tempo ou pelo foco da discussão ter sido direcionado para o processo como um todo e não especificamente no jogo em si.

Um outro aspecto a ser considerado em relação às formas de avaliação utilizadas nos jogos é o público-alvo a que se destina a avaliação, em alguns jogos (CEU, REG) a fase de avaliação fica restrita aos jogadores, enquanto nos outros (DA, EC) a avaliação destina-se também ao facilitador do jogo.

Quadro 10 - Formas de avaliação e o público-alvo

\begin{tabular}{|l|l|c|}
\hline Jogo & \multicolumn{1}{|c|}{ Forma de avaliação } & Público-alvo \\
\hline DA & $\begin{array}{l}\text { Há dois roteiros de avaliação propostos: um mais direcionado ao processo } \\
\text { de discussão em grupo e outro mais focado à análise dos resultados e na } \\
\text { eficácia de soluções encontradas durante o jogo para os problemas } \\
\text { enfrentados }\end{array}$ & $\begin{array}{c}\text { Jogador e } \\
\text { Facilitador }\end{array}$ \\
\hline EC & $\begin{array}{l}\text { Um questionário de avaliação sobre todo o curso do 'Estatuto da Cida de” } \\
\text { é aplicado ao final do jogo aos participantes. Neste questionário constam } \\
\text { perguntas sobre os diversos instrumentos do “Kit das Cidades", dentre eles } \\
\text { o jogo de papéis. }\end{array}$ & $\begin{array}{c}\text { Jogador e } \\
\text { Facilitador }\end{array}$ \\
\hline CEU & $\begin{array}{l}\text { Um roteiro de questões é proposto para discutir os conflitos identificados } \\
\text { durante o jogo, neste jogo, o tempo de discussão é extenso, uma vez que o o } \\
\text { jogo é apenas uma forma de sensibilizar os participantes sobre a } \\
\text { complexidade das questões do zoneamento urbano relativas à conservação } \\
\text { e ocupação. }\end{array}$ & Jogador \\
\hline REG & $\begin{array}{l}\text { A avaliação do jogo está inserida numa avaliação mais geral sobre ocurso } \\
\text { de 'Direito à Moradia” }\end{array}$ & Jogador \\
\hline
\end{tabular}

Fonte: elaborado pela autora. 


\subsection{DisCUSSÃO - LIMITES E POTENCIALIDADES DOS QUATRO JOGOS DE PAPÉIS ESTUdAdOS EM RELAÇÃo À PROPOSTA dA EdUCAÇÃo AMBIENTAL CRíTICA}

Os quatro jogos estudados lidam com questões semelhantes, mas apresentam diferentes contribuições à Educação Ambiental. Na discussão deste capítulo, pretendemos elucidar aspectos verificados nas diversas experiências de jogos de papéis que podem ser considerados potencialidades e limites deste tipo de ferramenta didática no que concerne à Educação Ambiental em sua vertente crítica. Esses pontos abordados a seguir servirão para dialogar com as hipóteses levantadas no presente estudo. Iniciaremos pelos aspectos que se situam no campo das potencialidades:

\subsubsection{Potencialidades}

\section{- A capacidade de explicitar a complexidade da situação}

De certo modo, todos apontam para a representação de uma realidade complexa permeada por diversos conflitos de interesses, envolvidos na gestão sócio-ambiental de áreas peri-urbanas. Os jogos de papéis enfatizam também a necessidade de participação, negociação e articulação entre os vários atores envolvidos no processo, através da vivência das situações de forma ativa durante o jogo.

Nos jogos estudados as situações-problema apresentadas buscam sempre um esclarecimento da complexidade do problema a partir da interligação e da interdependência dos diversos fatores envolvidos, principalmente através da integração das questões ambientais e sociais. Os jogos apresentam as situações-problema a partir dos conflitos e não da harmonia, neste sentido, trazem o conceito de complexidade proposto por Morin, em que complexo é o que foi "tecido junto", o que está interligado numa complementaridade contrária ao reducionismo (MORIN, 2004).

\section{- A possibilidade de vivência de uma situação de conflito}

A vivência proporcionada por este tipo de jogo pode contribuir na discussão de temas polêmicos, uma vez que a partir da representação de um papel, as pessoas podem se colocar mais facilmente na situação de um determinado sujeito ou grupo social envolvido 
na problemática, facilitando assim a "empatia" ou a capacidade de se colocar no lugar do outro, um dos pressupostos importantes para uma boa negociação.

A vivência de um papel implica também a necessidade de tomar decisões, o que envolve uma análise da situação e uma capacidade de interação com os outros jogadores e com o ambiente para perceber as possibilidades de ação.

A dinâmica proporcionada pelo jogo de papéis possibilita ainda um aprendizado ativo e não passivo, através da vivência e da prática, o que vai ao encontro das formas mais progressistas de educação, na qual o educando é também um sujeito no processo de aprendizagem e não apenas um receptor de informações.

- A capacidade de apresentar os múltiplos pontos de vista numa perspectiva integrada

O jogo de papéis (RPG) combina estes diferentes aspectos do aprendizado: conceitos, atitudes, estratégias e comportamentos e integra os aspectos técnicos e político-sociais essenciais na discussão dos problemas sócio-ambientais. Ao apresentar os vários "atores" envolvidos numa situação de conflito, o jogo traz à tona os vários interesses e requer uma negociação para o desenrolar do jogo. Neste sentido, o jogo de papéis pode

ser considerado como uma metodologia que valoriza a visão problematizadora de Educação (FREIRE, 2002), pois o grupo é que deve, a partir da discussão, chegar às soluções para a situação-problema.

\section{- A importância da mediação no processo de negociação de conflitos}

Todos os jogos estudados introduzem a questão da importância da mediação no processo de negociação de conflitos, pois existem papéis de mediação e também a possibilidade de escolha de um mediador entre os participantes/jogadores. Os participantes acabam assumindo papéis de "mediadores" ao organizar as reuniões e discussões sobre os conflitos apresentados no jogo.

\section{- O aspecto lúdico inerente ao jogo}


Um outro aspecto a ser ressaltado é o fato do jogo de papéis criar um ambiente descontraído e agradável, favorecendo a informalidade das relações, isso foi claramente observado nas sessões de jogo, os jogadores gostaram de jogar e se divertiram bastante atuando de acordo com os seus papéis e incorporando o personagem.

\subsubsection{Limites}

Em relação aos aspectos limitantes deste tipo de jogo, destacamos alguns que consideramos importantes de serem avaliados numa proposta de trabalho em Educação Ambiental, os quais enumeramos a seguir:

\section{- A importância da avaliação do jogo e o tempo disponível}

A fase de síntese ou avaliação final - debriefing - é essencial para dar sentido ao jogo, fazendo as relações das situações de jogo com as da realidade, a partir desta avaliação é que o jogo ganha sentido no contexto pedagógico, tornando-se uma atividade-meio e não um fim em si mesmo. No entanto, notamos em algumas das sessões assistidas, que o tempo destinado à avaliação muitas vezes não é suficiente para uma análise mais aprofundada, para que se possa fazer as relações pertinentes ao contexto da problemática abordada. O tempo é sem dúvida um fator limitante, uma sessão de jogo completa, incluindo uma avaliação aprofundada, requer no mínimo oito horas de trabalho, o que nem sempre é possível neste tipo de atividade.

\section{- O jogo como parte de um processo educativo mais amplo}

Todos os jogos estudados estavam inseridos num processo educativo mais amplo, um curso ou treinamento, os autores concordam que o jogo em si não consegue agregar todos os fatores importantes ao processo educativo, quando inserido num processo mais contínuo outros objetivos conseguem ser alcançados. Neste sentido, o jogo de papéis é um instrumento didático que pode potencializar uma discussão ou mobilizar os educandos para uma participação mais ativa nas questões sócio-ambientais se for introduzido num contexto e não apenas como uma atividade isolada. 
Em relação ao processo educativo, os jogos foram inseridos em momentos distintos do processo, os que foram utilizados no início mostraram contribuir para a motivação dos participantes e facilitaram a comunicação entre o grupo, nesta fase o jogo de papéis pode também ser útil para o diagnóstico da situação a partir das visões trazidas pelo grupo. No final do processo, o jogo de papéis foi utilizado para sintetizar ou discutir aspectos importantes do conteúdo abordado durante o curso. É fundamental considerar os objetivos que se pretende atingir com este tipo de jogos para que seja inserido no momento mais adequado do processo.

\section{- A disposição para a vivência}

Todos os entrevistados ressaltaram o poder de mobilização que o jogo de papéis desempenha, promovendo a discussão e a participação de conteúdos específicos, técnicos e muitas vezes de difícil entendimento. Por haver a necessidade de incorporar o papel, o jogo mobiliza as pessoas por completo, como no teatro em que o racional e o emocional estão presentes, é interessantepois evita de certa forma as dicotomias do objetivo/subjetivo, razão/emoção, ambiente/sociedade que ainda estão bastante presentes na educação mais tradicional. Esta possibilidade torna os jogos de papéis ferramentas muito promissoras na Educação Ambiental Crítica.

Entretanto, por ser uma dinâmica de vivência, o jogo pressupõe a participação de todos, se os participantes não se envolverem, o jogo pode ficar monótono e sem sentido. Por esse mesmo motivo, o jogo traz à tona sentimentos, emoções dos participantes, que muitas vezes incorporam plenamente o papel designado, é preciso que o facilitador do jogo esteja bem preparado para lidar com possíveis atritos entre os participantes, tendo a clareza do que é jogo e do que é realidade

\section{- A complexidade da dinâmica do jogo}

Em algumas sessões notamos que o entendimento das regras do jogo é um dos fatores essenciais para a participação. Alguns jogadores que não entenderam o funcionamento do jogo, simplesmente abandonaram o seu papel ou então jogaram de forma automática sem um maior envolvimento. Por tratar de situações complexas, o jogo de papéis (RPG) 
envolve uma série de possibilidades de ações integradas e consequentemente, uma série de regras e procedimentos a seguir. Deve-se sempre considerar o nível de complexidade possível em relação ao público-alvo para que não afaste as pessoas da dinâmica devido à falta de entendimento e compreensão do jogo em si, limitando assim a discussão do assunto em questão.

\section{- A singularidade de cada sessão de jogo}

As sessões de jogo são independentes e portanto podem trazer aspectos bastante diversos de uma situação, uma sessão nunca será igual a outra. Uma possibilidade interessante é jogar com dois ou mais grupos simultaneamente e, no final fazer a análise coletiva, buscando as diferentes estratégias de ação, comparando e discutindo as possibilidades, pode ser importante para iniciar uma análise mais completa da situação.

Uma outra dificuldade na EA é jogar com pessoas que não estão cientes da situaçãoproblema, ou que não estão familiarizadas com o conteúdo mais técnico abordado no jogo. Mesmo o jogo do Estatuto da Cidade (EC), que considerou diversos cenários em diferentes tipos de municípios brasileiros, apresenta uma grande quantidade de informações técnicas que geralmente são muito distantes da população em geral. Neste caso, o papel de um facilitador ou "mestre do jogo" é essencial para explicar as dúvidas e conduzir, mediar o jogo, a discussão. Se o facilitador não estiver muito bem preparado, torna-se difícil o desenrolar do jogo, neste sentido, a formação de multiplicadores é um aspecto a ser considerado.

Percebemos diversas possibilidades destes jogos em projetos de Educação ambiental e Educação não-formal de um modo geral. A vivência de uma situação-problema é algo que mais desperta o interesse nos participantes jogadores, assim como os aspectos lúdicos que dão um diferencial à dinâmica e trazem as singularidades do jogo em relação a outras dinâmicas de grupo.

No entanto, o jogo quando utilizado como uma forma de transmissão de conteúdos de difícil compreensão pode tornar-se cansativo devido ao excesso de informações que é preciso saber para jogar, chegando até mesmo a perder o seu caráter lúdico. 
Uma das grandes limitações deste tipo de jogo na EA reside na relação entre a complexidade, possibilidades didáticas, público-alvo e o tempo de duração de uma sessão de jogo. Um jogo muito simples pode limitar a abordagem complexa do assunto, limitando-se aos aspectos lúdicos do jogo, por outro lado, um jogo muito complexo, torna-se difícil de entender e limita o seu alcance.

Finalmente, é importante ressaltar o fato de que por termos assistido a poucas sessões de jogo e, devido ao fato da singularidade de cada sessão de jogo, podemos ter tido algumas observações equivocadas que poderiam ter sido modificadas em outras sessões com grupos diferentes.

No entanto, as entrevistas com os autores e a análise do material de jogo possibilitou-nos uma combinação de materiais que de certa forma ampliam a pesquisa, não restringindo apenas à observação das sessões.

Pretendemos com este levantamento apresentar um panorama dos jogos de papéis desenvolvidos em experiências brasileiras que abordam os desafios da participação dos movimentos populares da sociedade, agregando também critérios de comparação e análise que podem ser úteis em estudos próximos referentes ao tema. Temos consciência que não esgotamos a análise e que um acompanhamento mais próximo das sessões de cada um dos jogos pode resgatar novos elementos de discussão.

Esta etapa da pesquisa leva-nos a próxima etapa na qual foi possível um acompanhamento aprofundado de um jogo de papéis, com simulação. A breve análise dos jogos tradicionais foi também essencial na comparação e no entendimento de um jogo com simulação de cenários, protótipo de jogo com modelagem de acompanhamento, desenvolvido pelo Projeto Negowat. A partir desta primeira etapa, as possibilidades e os limites de um jogo de papéis com este enfoque também aparecem mais com maior clareza. 


\section{ANÁlISE DO JOGO DOS MANANCIAIS A PARTIR DAS PERCEPÇÕES DE UM PÚBLICO DE ESTUDANTES: ELEMENTOS PARA REFLETIR SOBRE AS POSSIBILIDADES E LIMITES DE UM JOGO DE PAPÉIS COM SIMULAÇÃO DE CENÁRIOS}

Depois de apresentar um panorama dos tipos de jogos de papéis que correspondem às experiências brasileiras na área de formação, conforme o levantamento e a comparação dos jogos selecionados neste estudo, procedemos à análise de um jogo de papéis, com simulação de cenários, desenvolvido no âmbito do Projeto Negowat. Neste capítulo apresentamos e analisamos em detalhe o jogo de papéis que se constitui como o foco da nossa pesquisa: "O Jogo dos Mananciais"(MAN).

Para tanto, o capítulo encontra-se dividido em quatro partes: nas três primeiras explicitamos o processo de construção do jogo, sua inserção dentro do Projeto Negowat, a apresentação detalhada do mesmo e as singularidades deste jogo em relação aos anteriores. Na última parte do capítulo, apresentamos os resultados da aplicação do jogo em sessões de teste nas várias universidades e o público-alvo a quem se destina; assim como a discussão dos resultados obtidos, analisando-os a partir das percepções dos jogadores participantes. Desta forma teremos elementos para discutir as posssibilidades e as limitações de um jogo de papéis com simulação dentro da proposta de uma Educação Ambiental em sua vertente crítica.

\subsection{O PROCESSO DE CONSTRUÇÃO DO JOGO E SEUS OBJETIVOS}

O Jogo dos Mananciais foi o primeiro jogo desenvolvido no Projeto Negowat, a partir dos referenciais do "enfoque da modelagem de acompanhamento" e da "aprendizagem social" que orientam o Projeto. Daí a sua característica de "protótipo", cujo processo de elaboração serviu para capacitar a equipe interna sobre o desenvolvimento desse tipo de jogo de papéis e da organização de uma sessão de jogo (material de apresentação, fichas dos jogadores e fase de debriefing ou avaliação final do jogo). Depois desta primeira fase de capacitação interna no desenvolvimento da ferramenta, passamos aos testes de jogo para a validação do material com estudantes de graduação e, posteriormente de pósgraduação. 
O Jogo dos Mananciais (MAN) parte de uma visão acadêmica dos pesquisadores do Projeto Negowat sobre os conflitos de uso e ocupação do solo. Ao longo desta pesquisa, dedicamos um maior tempo a esse jogo. Desde a elaboração do material de jogo a partir da transposição didática até a aplicação do jogo em sessões de teste para estudantes de graduação e pós-graduação. Ao longo das sessões de teste, o jogo sofreu diversas adaptações com o objetivo de incluir as críticas e sugestões relevantes do público, esclarecendo dúvidas e aprimorando o material de jogo, num processo de pesquisa-ação

Este jogo difere dos tradicionais jogos de papéis como os selecionados e apresentados no capítulo anterior porque envolve a simulação de cenários através de um modelo multiagente $^{18}$ acoplado ao jogo. Desta forma, ao longo das jogadas, os jogadores podem visualizar as ações realizadas e seus impactos na região onde ocorre a ação do jogo.

O jogo apresenta os princípios da abordagem da modelagem de acompanhamento, mas pode ser considerado ainda como um protótipo de jogo ComMod, uma vez que sua concepção está pautada numa visão acadêmica, um tanto distante da realidade e que não prevê a aplicação com os atores locais.

Atualmente encontra-se em fase de desenvolvimento um outro jogo de papéis intitulado "TerAguas", o qual será aplicado com atores locais e que corresponde a um processo mais amplo que inclui um jogo-maquete, um jogo computadorizado e um processo de intervenção com os grupos locais. Ao final do capítulo apresentaremos em detalhe as perspectivas do projeto Negowat e as possibilidades dos jogos em desenvolvimento.

O Jogo dos Mananciais (MAN) apresenta como objetivo geral discutir as formas de uso e ocupação do solo e da água em regiões peri-urbanas e introduzir a idéia da gestão participativa, integrada e descentralizada dos recursos hídricos através da vivência de uma reunião simulada do Comitê de Bacia.

\footnotetext{
${ }^{18}$ Modelo JogoMan - um software desenvolvido na plataforma Cormas (Common Pool Resources and Multi-Agent Systems) por Raphaele Ducrot, Jaime Sichman e Diana Adamatti LTI / POLI USP
} 
(MAN) foi desenvolvido para ser utilizado em cursos universitários, tanto de graduação quanto de pós-graduação, da área ambiental ou para técnicos com foco na gestão integrada dos recursos hídricos.

Em relação aos objetivos específicos, o jogo pode ser explorado com maior ênfase em duas direções, em função dos conteúdos que se pretende explorar e do público-alvo:

\section{- Formação em gestão integrada de recursos hídricos numa bacia peri-urbana.}

Neste sentido, o jogo evidencia as estreitas relações existentes entre o uso e ocupação do solo, a gestão da água e a gestão urbana e possibilita discussões nos seguintes aspectos: (i) Participação e representação numa base de múltiplos atores envolvidos; (ii) desenvolvimento de reuniões do comitê - Simulação de uma reunião do Comitê de bacia; (iii) processo de planejamento; (iv) Elaboração de novas regras; (v) processo de implementação de novos acordos;

- Formação em habilidades de negociação para um planejamento estratégico ou para a resolução de conflitos

Para o público especialmente interessado em formação em técnicas de negociação, o jogo possibilita também uma discussão e vivência sobre vários aspectos do processo de negociação: (i) implementação de mecanismos de coordenação de grupo; (ii) entendimento de valores, interesses e sensibilidade de riscos; (iii) gerenciamento de informações técnicas na negociação; (iv) avaliação de acordos e (v) técnicas de negociação (aspectos políticos, opções fechadas)

\subsection{APRESENTAÇÃo do JOGO}

\section{A situação-problema}

O Jogo dos Mananciais é um jogo de papéis computadorizado que simula o funcionamento de uma bacia hidrográfica peri-urbana, na qual os recursos hídricos estão em processo de rápida degradação devido à crescente urbanização e condições 
inadequadas de saneamento. Trata-se de uma bacia abstrata, virtual que não existe na realidade.

\section{Os personagens / jogadores}

1. O Prefeito dos municípios, encarregado do desenvolvimento de infra-estrutura no território municipal.

2. O gerente da Companhia de água e saneamento, que gerencia e implementa infraestrutura para tratamento e distribuição de água potável, e serviços de coleta e tratamento de esgotos.

3. Proprietários de terra com estratégias iniciais distintas (agricultor tradicional, especulador imobiliário, ambientalista, etc)

4. Representantes das famílias que chegam à região em busca de moradia popular e emprego

5. Representante da Secretaria do Meio Ambiente encarregado de implementar uma nova política de uso da água, baseada na gestão integrada dos recursos hídricos

\section{A dinâmica de jogo}

Os jogadores devem realizar tarefas que envolvem a tomada de decisão, negociação, comunicação e interação com os outros atores. O jogo é estruturado em três fases: 1 . tomada de decisão individual: estágio no qual cada jogador define e implementa suas próprias estratégias em relação ao uso e ocupação do solo e desenvolvimento de infraestrutura, 2. tomada de decisão coletiva no final de cada rodada, representada pela reunião do Comitê da Bacia para avaliar a situação e buscar soluções. Os acordos firmados nesta fase podem ser implementados na rodada seguinte. A sessão de jogo finaliza com uma fase de debriefing (síntese final - $3^{\circ}$ fase), que é um momento importante para analisar e discutir os resultados da sessão de jogo. 


\subsection{SINGULARIDADES DO JOGO DOS MANANCIAIS EM RELAÇÃO AOS ANTERIORES}

Com relação ao Jogo dos Mananciais (MAN) ocorre uma diferenciação em relação aos anteriores, uma vez que pode ser definido como um jogo de papéis apoiado por um sistema de simulação computadorizada, ou seja, tem como base um modelo multi-agente de mesmo nome. Esse jogo destaca-se por ser o único jogo computadorizado, com base num programa (software) de simulação de cenários e por estar relacionado a um projeto de pesquisa inter-institucional que congrega instituições brasileiras e européias (Projeto Negowat) que tem utilizado a abordagem da modelagem multi-agente, com base na abordagem da modelagem de acompanhamento (ComMod-Companion modeling approach) para o desenvolvimento de ferramentas de apoio a negociação e participação nos conflitos sócio-ambientais (BARRETEA et al, 2003).

A hipótese deste grupo de pesquisadores é que na gestão dos recursos naturais, os atores envolvidos precisam mais do que uma troca de visões sobre o problema em questão, mas sim um verdadeiro processo de aprendizado que envolva as interações dos atores locais e técnicos para um suporte à negociação de conflitos. Neste sentido, é importante enriquecer o processo em termos técnicos e sociais, de forma a "empoderar" os atores mais marginalizados no processo. O processo de modelagem, seja através de um modelo multi-agente ou de um jogo de papéis, pretende um reconhecimento mútuo de todos os envolvidos no processo, mais do que apenas uma simplificação da realidade, o que é caracterizado por um "modelo participativo" (BARRETEA et al, 2003).

Conforme apresentado, o Jogo dos Mananciais apresenta algumas características distintas dos jogos de papéis tradiconais selecionados neste estudo. Para evidenciar estas especificidades deste jogo, procedemos a uma comparação do mesmo em relação aos outros jogos, seguindo os mesmos critérios de análise. Tal comparação permitirá uma melhor visualização das semelhanças e diferenças do Jogo dos Mananciais em relação aos jogos de papéis tradicionais, buscando, da mesma forma, seus limites e potencialidades em projetos de Educação Ambiental. 


\section{O público-alvo}

Ao contrário dos outros jogos, que apresentam como público-alvo técnicos ou atores locais de movimentos sociais, o Jogo dos Mananciais (MAN) foi desenvolvido para formação acadêmica e testado com estudantes de graduação e pós-graduação de cursos ligados à área ambiental, ainda de forma restrita. Neste sentido não pode ser considerado totalmente um jogo pautado na modelagem de acompanhamento, pois esta pressupõe a participação de atores locais. O Jogo dos Mananciais apresenta vários problemas de calibragem e de representação que impedem sua aplicação por atores locais, entretando pode ser um instrumento de formação acadêmica para atores mais distantes do processo.

\section{O contexto de utilização do jogo durante o processo educativo}

O jogo dos Mananciais (MAN) foi desenvolvido para ser utilizado em cursos acadêmicos na área da gestão integrada dos recursos naturais, especialmente dos recursos hídricos. O processo completo no qual se insere o jogo compreenderia um curso de 12 horas, o que inclui um primeiro módulo sobre legislação e o sistema de gestão integrada dos recursos hídricos, a sessão de jogo e um terceiro módulo a partir da discussão do jogo, sintetizando os desafios encontrados e as possíveis soluções discutidas. Desta forma, seria utilizado durante o processo educativo assim como o jogo Desafio das Águas (DA).

\section{O ambiente de jogo (cenário, espaço e tempo)}

O Jogo dos Mananciais (MAN) é o único que apresenta um mapa abstrato, representando parcelas quadriculadas correspondentes aos lotes. Em todos os outros jogos temos bairros ou cidades imaginárias com nomes inventados que nos remetem aos locais da ação. Os tabuleiros, de um modo geral, são utilizados como cenário do jogo, apenas neste jogo que há mapas individuais que servem de suporte aos jogadores para anotarem e monitorarem as suas ações.. O cenário neste jogo não é apenas um mecanismo de ilustração do jogo, mas também um suporte de ação, localização e tomada de decisão para os jogadores.

No jogo (MAN), as informações de localização ou os mapas de jogo, não são compartilhados por todos os jogadores, há mapas distintos de acordo com o papel. Por 
exemplo, o prefeito possui as informações relativas ao seu município, mas não tem acesso às informações do municipio vizinho; enquanto o ambientalista dispõe do mapa completo da região. Esta separação de informações pode ser reforçada pela organização da sala de jogo, colocando os jogadores de cada município em um canto da sala, por exemplo e ao final de cada rodada, promover discussões coletivas que vão obrigar os jogadores a se deslocarem pela sala. Esta pode ser também uma forma de comparar estratégias distintas entre os vários grupos de jogadores.

Quadro 11 - Elementos do cenário no Jogo dos Mananciais (MAN)

\begin{tabular}{|c|c|c|c|}
\hline Jogo & Elementos do cenário & Função & Imagem \\
\hline MAN & $\begin{array}{l}\text { Mapa modelizado com diferentes } \\
\text { parcelas (lotes) e usos do solo (ex.: } \\
\text { floresta, agricultura, campo) na } \\
\text { região. Representa o reservatório e } \\
\text { estação de tratamento, os municipios } \\
\text { com areas urbanas e infra-estruturas. }\end{array}$ & $\begin{array}{l}\text { Ilustração e } \\
\text { suporte para } \\
\text { os jogadores. }\end{array}$ & \\
\hline
\end{tabular}

Fonte: elaborado pela autora.

\section{A organização do tempo de jogo}

Sobre o tempo, o Jogo dos Mananciais (MAN) apresenta divisão em rodadas como o Jogo da Construção do Espaço Urbano (CEU). No entanto, as rodadas do (MAN) são mais rápidas (de 10 a $15 \mathrm{~min}$ ) e representam um ano da realidade. Esta rapidez das rodadas contribui para evidenciar o impacto da rápida dinâmica de alteração dos usos do solo e da água nas regiões de periferia de uma grande metrópole. Neste caso, a rapidez das rodadas é importante para a visualização da mudança rápida de cenários que o jogo pretende explicitar.

O quadro abaixo mostra a organização do tempo de jogo no Jogo dos Mananciais (MAN).

Quadro 12 - Organização do tempo no Jogo dos Mananciais (MAN)

\begin{tabular}{|c|l|c|}
\hline Jogo & \multicolumn{1}{|c|}{ Organização do tempo } & Duração da sessão de jogo \\
\hline MAN & $\begin{array}{l}\text { De 3 a } 5 \text { Rodadas } \\
\text { (cada rodada corresponde a 1 ano) }\end{array}$ & $\begin{array}{c}\text { 4 horas (incluindo o tempo de introdução } \\
\text { e apresentação do jogo) }\end{array}$ \\
\hline
\end{tabular}

Fonte: elaborado pela autora. 


\section{Tarefas solicitadas aos jogadores}

(MAN) é um jogo que combina os dois tipos de tarefas, o que inclui não apenas o deslocamento dos jogadores pela sala de jogo, mas também diferentes tarefas intelectuais (tomada de decisão individual e coletiva, cálculos, negociação de preços e discussão coletiva).

O jogo (MAN) apresenta tarefas individuais e coletivas durante os diversos momentos do jogo, como pode ser verificado no diagrama abaixo (Figura 16 - Diagrama da Sessão (MAN) ). Cada jogador pode escolher uma estratégia de ação, mais individual ou mais coletiva, através das negociações, a estratégia de jogo pode ser alterada em função da mudança do cenário, do uso do solo e da água.

Figura 15 - Diagrama da Sessão (MAN)

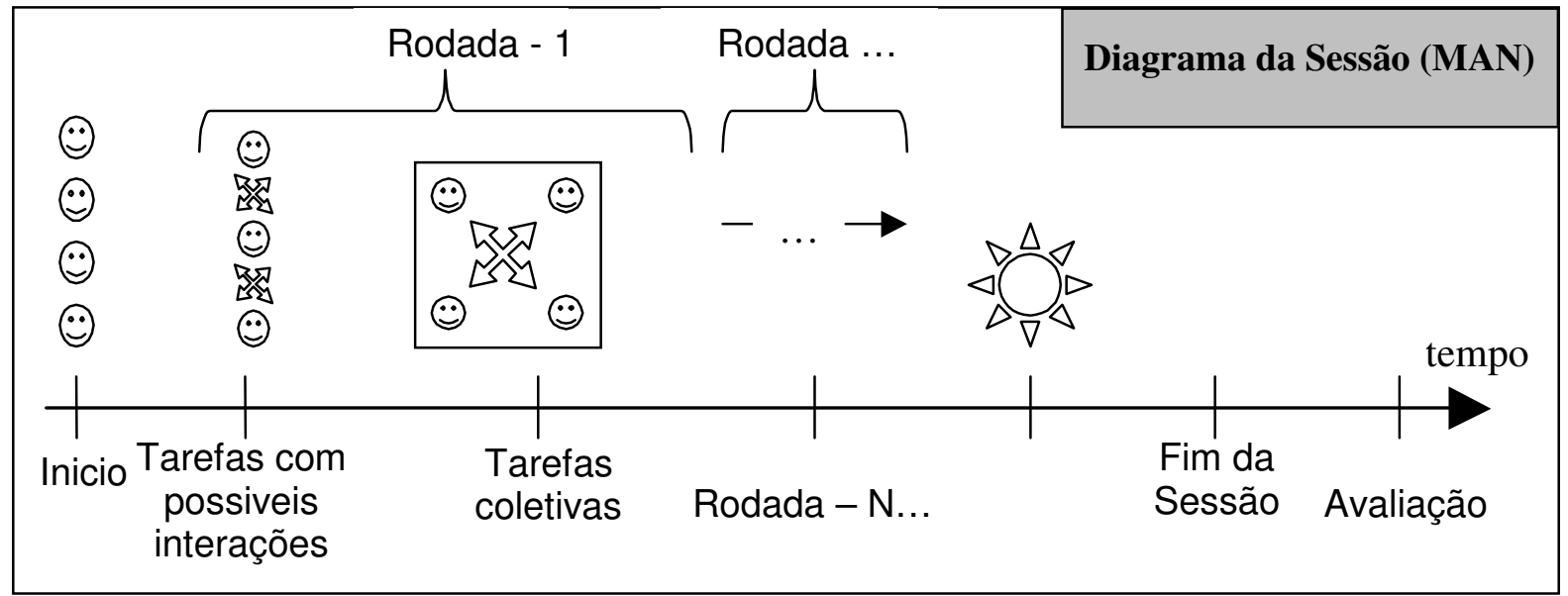

Fonte: elaborado pela autora.

Figura 16 - Legenda dos Diagramas.

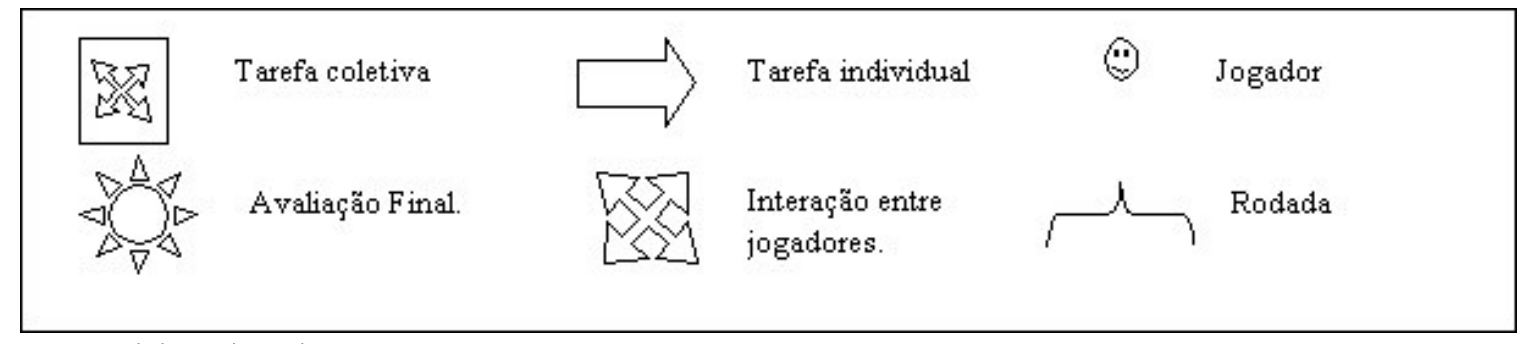

Fonte: elaborado pela autora. 
O jogo (MAN) apresenta diferentes níveis de interação durante a sessão de jogo. Cada rodada possui um tempo para ações individuais (escolher os possíveis usos do solo para a sua propriedade) e possíveis negociações bilaterais (comprar ou vender propriedades).

Figura 17 - Gráfico dos RPGs de acordo com os tipos de tarefas

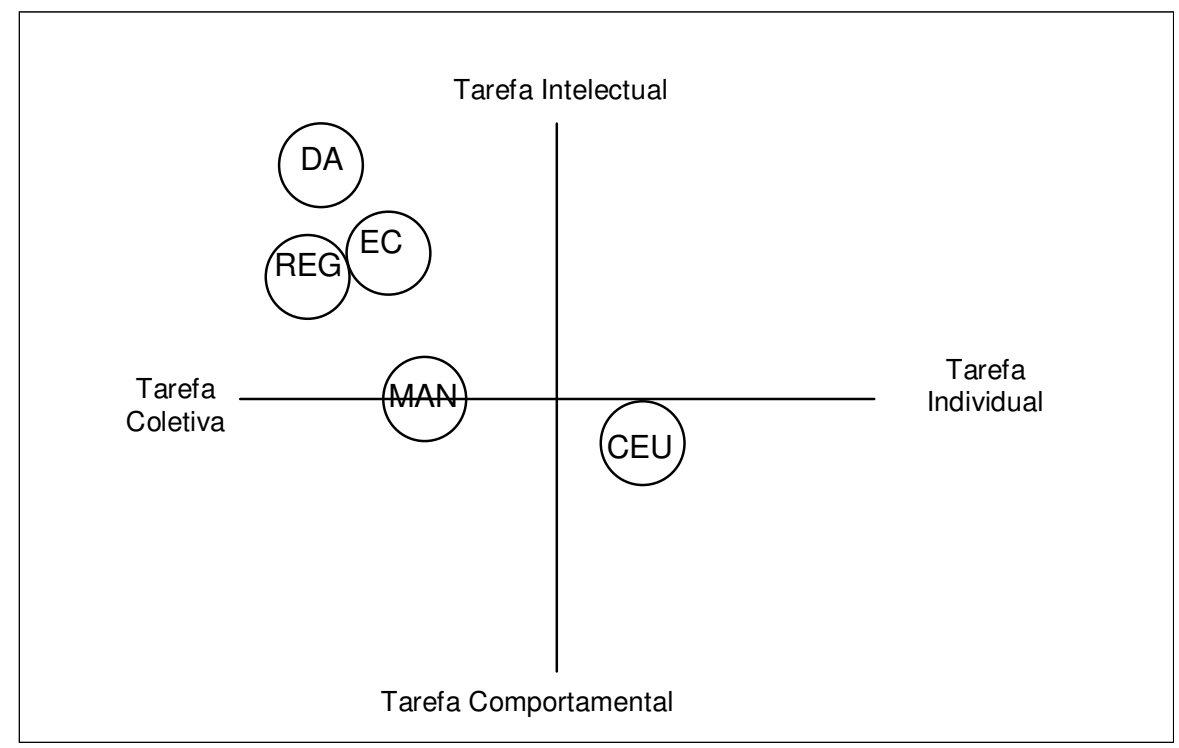

Fonte: elaborado pela autora

No final de cada rodada há uma discussão coletiva que simula uma reunião do comitê de bacia, da qual participam os vários atores. Esta sucessão de eventos permite a discussão da articulação das estratégias individuais com as coletivas tomadas de decisão, bem como explicita as dificuldades de implementação dos acordos coletivos. O monitoramento de sessões deste jogo demonstrou que nas primeiras rodadas, os jogadores se concentram nas ações individuais, a medida que o jogo se desenvolve a discussão coletiva e as negociações em grupos intensificam-se. 


\section{Características dos papéis / personagens do jogo}

Quadro 13 - Tipos de papéis nos jogos analisados

\begin{tabular}{|c|l|l|}
\hline Jogo & Tipo de papéis & $\begin{array}{l}\text { Informações disponíveis na descrição dos } \\
\text { papéis }\end{array}$ \\
\hline (MAN) & $\begin{array}{l}\text { Prefeito, proprietários de terra, Secretaria } \\
\text { do Meio Ambiente, técnico da empresa } \\
\text { de água }\end{array}$ & $\begin{array}{l}\text { Descrição completa do cargo e funções, } \\
\text { saldo bancário, possibilidades de ação no } \\
\text { jogo }\end{array}$ \\
\hline
\end{tabular}

Fonte: elaborado pela autora.

Em todos os jogos um papel é exclusivo de um determinado jogador, exceto no (MAN), que compreende poucos tipos de papéis (prefeito, proprietário, Secretaria do Meio Ambiente, e representantes dos movimentos sociais), mas que podem ser desempenhados por vários jogadores como por exemplo: 3 prefeitos, 9 proprietários, 2 representantes de movimentos sociais. As estratégias de cada ator podem ser analisadas e comparadas posteriormente ao final da rodada.

\section{Formas de avaliação}

Todos os jogos de papéis descritos apresentam uma avaliação final, no entanto apenas o jogo (MAN) distingue claramente a avaliação do jogo propriamente dito, que corresponde às estratégias e ações dos jogadores durante a sessão de jogo, do processo de aprendizado proporcionado pelo jogo, de forma mais ampla.

No jogo (MAN) a fase de síntese ou avaliação final (debriefing) foi sistematicamente realizada, uma vez que analisar o jogo era o foco da intervenção.

A avaliação do Jogo dos Mananciais está descrita abaixo:

Quadro 14 - Formas de avaliação no Jogo dos Mananciais em relação ao público-alvo

\begin{tabular}{|l|l|l|}
\hline Jogo & \multicolumn{1}{|c|}{ Forma de avaliação } & Público-alvo \\
\hline MAN & $\begin{array}{l}\text { O material de jogo inclui um roteiro de questões para o “debriefing”ou } \\
\text { avaliação final com duas orientações possíveis: uma com foco na gestão } \\
\text { dos recursos hídricos em seus aspectos mais técnicos e outra com foco nos } \\
\text { aspectos mais sociais, referents ao processo de negociação de conflitos. Há }\end{array}$ & $\begin{array}{l}\text { Jogador } \\
\text { Facilitador } \\
\text { Observadores } \\
\text { (equipe de }\end{array}$ \\
\hline
\end{tabular}




\begin{tabular}{|l|l|l|}
\hline $\begin{array}{l}\text { ainda um questionário de avaliação dirigido aos participantes e um roteiro } \\
\text { de questões para os observadores da sessão (membros da equipe) que } \\
\text { auxiliam no monitoramento da sessão (em anexo). }\end{array}$ & suporte) \\
\hline
\end{tabular}

Fonte: elaborado pela autora.

No (MAN) existem ainda observadores da equipe de suporte que ajudam na avaliação do jogo, realizando o que se poderia denominar de uma “observação participante”.

Quando analisado em comparação com os outros jogos, percebemos algumas possibilidades e muitas das limitações do Jogo dos Mananciais. O fato deste jogo possibilitar a simulação de cenários faz com tenha um nível maior de complexidade, as rodadas ficam mais dinâmicas, no entanto a grande discussão que os jogos anteriores promovem, no (MAN) é limitada à reunião simulada do Comitê de Bacia. Em relação à situação-problema verificamos algumas incoerências no modelo que podem levar a uma realidade equivocada. Da mesma forma, os papéis, principalmente dos movimentos sociais de luta por moradia (os "sem-teto") aparecem um tanto equivocados quando confrontados com a realidade. Nestes problemas verificados no Jogo dos Mananciais, percebemos os desafios de elaborar um jogo de papéis complexo, mas que faça sentido aos moradores e atores locais de determinada região que se pretende explorar. A existência de uma avaliação sistematizada da sessão de jogo é um dos pontos positivos do (MAN) em relação aos anteriores, no entanto, vale ressaltar que o Jogo foi aplicado isoladamente e não como parte de um curso, conforme os outros selecionados.

A existência de tarefas individuais e coletivas é algo que torna o Jogo dos Mananciais diferente dos outros. Com exceção do (CEU) que apresenta tarefas individuais como forma de demonstrar uma lógica de exclusão urbana, os outros jogos baseiam-se em grandes tarefas coletivas, discussões para a construção de acordos que muitas vezes não abordam os aspectos individuais de uma negociação de conflitos. Nos outros jogos, o caráter individual da ação dos jogadores é dado apenas pelas características psicológicas que acabam por criar estereótipos. No Jogo dos Mananciais, os jogadores são livres para ações individualistas e estas são mais visíveis através da implementação no sistema informatizado. Esta é uma das possibilidades de um jogo com simulação que ressalta a dificuldade em conciliar interesses individuais e coletivos, da lógica da negociação. 
A partir da análise mais aprofundada das sessões de teste do Jogo dos Mananciais, as características deste jogo serão evidenciadas e as diferenças e semelhanças em relação aos jogos de papéis tradicionais tornar-se-ão mais claras.

\subsection{ANÁLISE DAS SESSÕES-TESTE DO JOGO DOS MANANCIAIS (MAN): RESULTADOS OBTIDOS E DISCUSSÃO}

Conforme mencionado no capítulo anterior referente à metodologia da pesquisa, nesta parte apresentaremos os resultados obtidos com as sessões- teste do Jogo dos Mananciais (MAN). As sessões de jogo foram realizadas com estudantes de graduação de cursos de Ciências Biológicas e de pós-graduação de cursos interdisciplinares da área ambiental. No total realizamos cinco sessões de teste e aprimoramento do jogo nas respectivas datas e universidades descritas no quadro abaixo:

Quadro 15 - Relação das sessões-teste do Jogo dos Mananciais

\begin{tabular}{|c|l|l|c|}
\hline \multicolumn{1}{|c|}{ Data } & \multicolumn{1}{|c|}{ Local } & \multicolumn{1}{c|}{ Nível } & N.de participantes \\
\hline $22 / 10 / 04$ & Universidade de Santo Amaro - Unisa & Graduação & 19 \\
\hline $29 / 10 / 04$ & $\begin{array}{l}\text { Programa de Pós-graduação em Ciência } \\
\text { Ambiental- Procam /USP }\end{array}$ & Pós-graduação & 9 \\
\hline $11 / 11 / 04$ & Faculdades Integradas Guarulhos - FIG & Graduação & 13 \\
\hline $25 / 02 / 05$ & Faculdade de Saúde Pública - USP & Pós-graduação & 16 \\
\hline $02 / 04 / 05$ & Universidade Mogi das Cruzes - UMC & Pós-graduação & 20 \\
\hline \multicolumn{2}{|c|}{ Total de participantes } & $\mathbf{7 7}$ \\
\hline
\end{tabular}

A análise das sessões deu-se a partir de vários aspectos: (1) análise dos questionários preenchidos pelos participantes ao final do jogo; (2) análise do "debriefing" ou síntese final, discussão considerada a cada sessão; (3) observação participante por parte do facilitador e (4) observação de alguns membros da equipe quando possível. A análise que trazemos aqui é uma síntese desses vários aspectos observados ao longo das sessões de jogo juntamente com os aspectos mais quantificáveis das respostas dos questionários aplicados para uma melhor visualização. Vale ressaltar que os aspectos mais destacados na análise buscaram a percepção dos jogadores em relação ao jogo e seu conteúdo através da observação das sessões, das discussões em grupo e das respostas dos questionários aplicados ao final e, em alguns casos, no início do jogo. 
Figura 18 - Foto ilustrativa de uma sessão do Jogo dos Mananciais

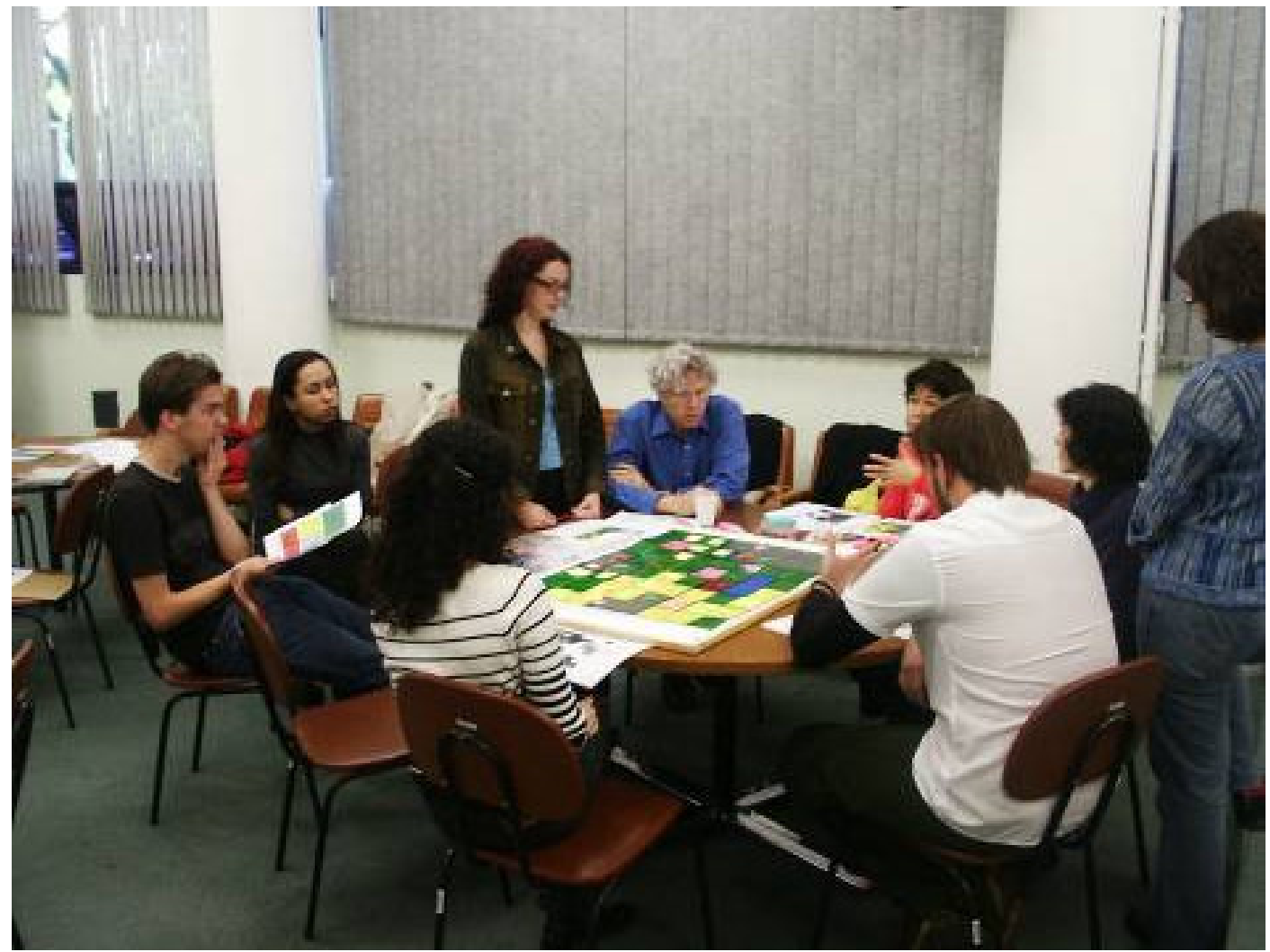

Fonte: R.Ducrot, 2004

Os questionários apresentavam-se não só como um registro das impressões que os participantes tiveram como jogadores durante a sessão, mas também como uma forma de perceber críticas e sugestões para o aprimoramento do jogo como ferramenta didática ao longo das várias sessões de teste (vide questionário em anexo).

Nas sessões de jogo realizadas com os estudantes da pós-graduação das faculdades Saúde Pública da UPS (FSP-USP) e Universidade de Mogi das Cruzes (UMC) aplicamos questionários iniciais, antes do início do jogo, para saber o grau de conhecimento dos alunos em relação a esse tipo de dinâmica e também suas expectativas em relação aos mesmos. No total de questionários iniciais respondidos tivemos 36. Na tabulação dos dados para a elaboração dos gráficos foram registrados o número de ocorrências de determinada resposta. Apresentamos os resultados a seguir: 


\subsubsection{Resultados obtidos nas sessões de jogo}

Foram aplicados questionários finais em todas as cinco sessões realizadas para os participantes responderem depois de participarem da sessão do jogo, num total de 74 questionários respondidos. As questões deste instrumento de avaliação do jogo versavam sobre as impressões em relação ao jogo (aspectos do jogo); as dificuldades e desafios percebidos durante a dinâmica; os aprendizados em relação à gestão dos recursos hídricos; os aprendizados em relação à negociação; aspectos da vivência de uma reunião do Comitê de Bacia e finalmente críticas e sugestões referentes ao jogo. Cada uma dessas variáveis pode ser visualizada nos gráficos. Em relação aos resultados, dividimos os participantes em dois grupos: (1) os estudantes de graduação e (2) os de pós-graduação, pois estes últimos apresentavam uma maior familiaridade com o assunto, uma vez que os problemas sócio-ambientais, de um modo geral, são temas tratados ao longo dos cursos.

- Aspectos do jogo

Figura 19 - Gráfico "Aspectos do Jogo"(Graduação e Pós -Graduação)

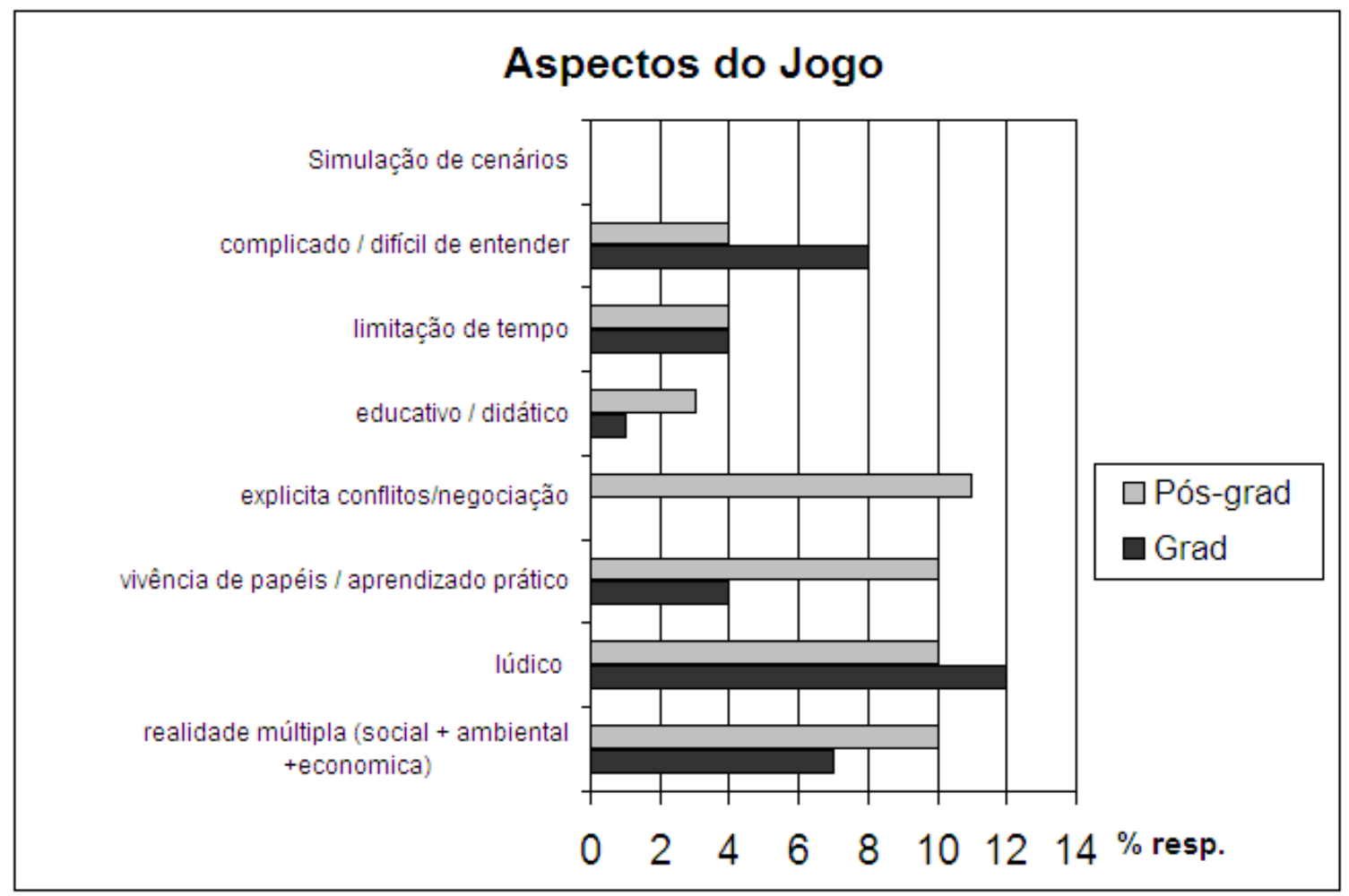

Fonte: elaborado pela autora. 
Sobre os aspectos do jogo, os resultados podem ser visualizados no grafico anterior.A tabulação dos resultados está dividida nos questionários respondidos pelo grupo de estudantes da pós-graduação e pelo grupo de estudantes da graduação. A maioria dos comentários dos estudantes da graduação (34\%) cita os aspectos lúdicos do jogo, dizendo que se divertiram ao jogar. Em, seguida, está o fato do jogo ser complicado e difícil de entender (22\%), a capacidade do jogo em mostrar a realidade em seus múltiplos aspectos (19\%). A possibilidade da vivência de papéis e a limitação de tempo de jogo foram mencionados por $11 \%$ dos participantes e $3 \%$ mencionaram o fato do jogo ser educativo e didático.

Já os estudantes da pós-graduação notaram em sua maior parte $(21 \%)$ a capacidade do jogo explicitar os conflitos e a negociação necessária à discussão dos mesmos. A existência de uma realidade múltipla nos seus vários aspectos: econômicos, políticos, sociais e ambientais foi também algo percebido por $19 \%$ dos participantes. Assim como os aspectos lúdicos e a vivência de papéis também foram citados pela mesma porcentagem de jogadores. $\mathrm{O}$ aspecto complicado e de difícil compreensão do jogo foram mencionados por $8 \%$ dos participantes, assim como a limitação do tempo do jogo; $6 \%$ citaram os aspectos educativos e didáticos do jogo.

Algumas falas dos participantes valem a pena de serem mencionadas para exemplificar como os jogadores perceberam o jogo, de um modo geral:

“Gostei do jogo porque treina o "Sair de si”, de suas seguras opiniões e enxergar os outros. Queria jogar para aprender mais a arte da negociação construtiva"

"A vivência de forma lúdica sendo mais interessante para percebermos o que acontece no dia a dia."

"Achei o jogo interessante, porque foi envolvente e muito prático, justamente pelo fato de no jogo termos atuado como cidadãos mesmo"

"Mostrou como o conflito de interesses pode afetar o desenvolvimento de uma área, notou-se que o conceito de sustentabilidade nem sempre era observado" 
'O jogo retrata bem as desigualdades no acesso a recursos (era muito cômodo e fácil enriquecer como proprietário de terras que não comprei, praticamente tomando conta do município), os órgãos públicos sofriam com a muita demanda e poucos recursos para atendê-las, num jogo de empurra-empurra de competências; as pessoas estavam confusas em relação ao seu papel dentro do comitê e somente informavam sobre as ações já realizadas. $O$ órgão ambiental não conseguia cumprir seu papel, dentro ou fora do comitê por falta de recursos financeiros e humanos."

- Dificuldades e Desafios

Figura 20 - Gráfico ‘Dificuldades e Desafios do Jogo”(Graduação e Pós -Graduação)

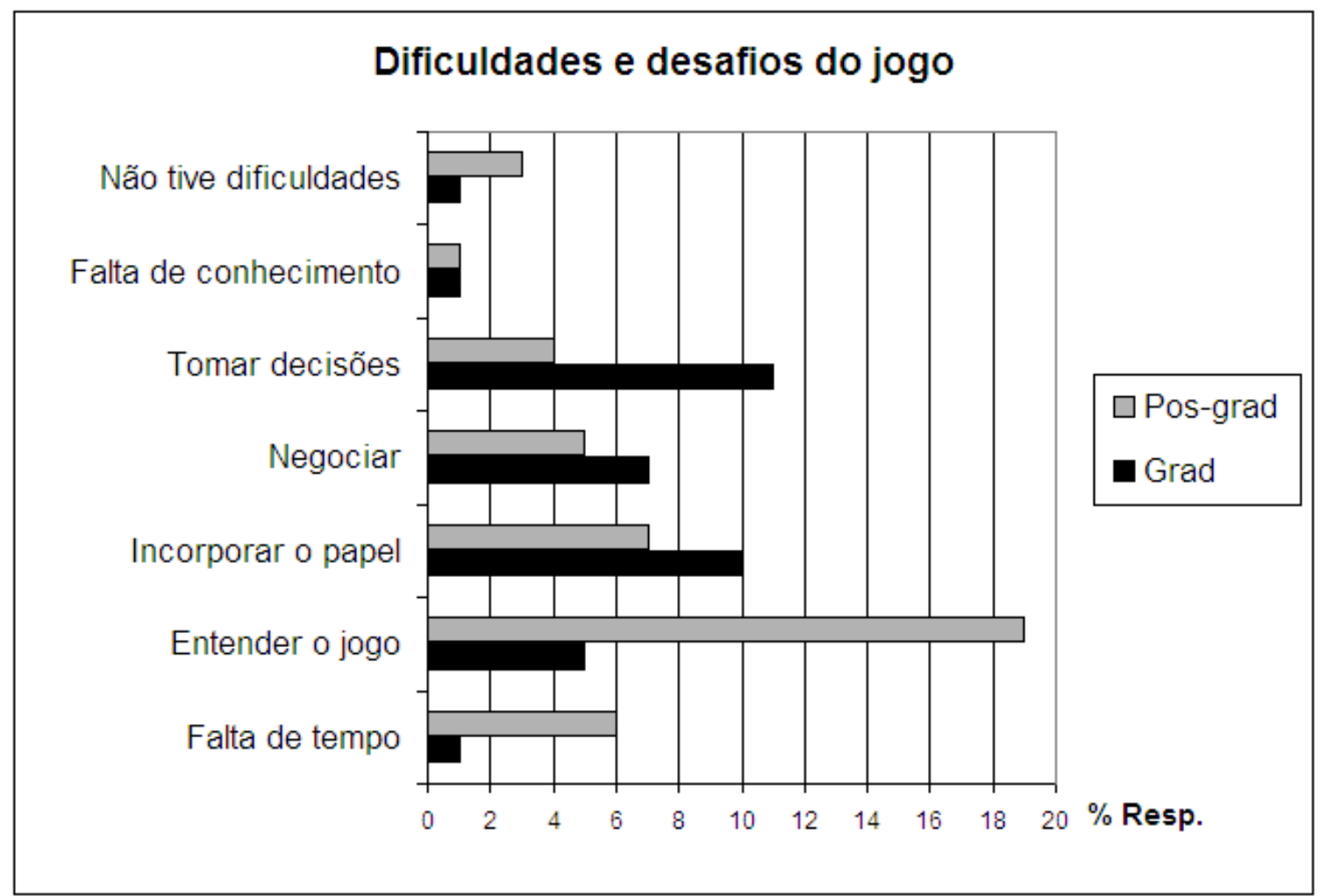

Fonte: elaborado pela autora.

Os estudantes da graduação perceberam o processo de tomada de decisões como uma dificuldade, $30 \%$ dos participantes citaram este aspecto, em seguida incorporar o papel do personagem foi citado por $28 \%$ do grupo. A dificuldade em negociar e entender o jogo, de forma geral foram aspectos citados por 19 e $14 \%$ dos participantes, respectivamente. Apenas 3\% do grupo mencionou a falta de tempo, a falta de 
conhecimento como dificuldades e desafios do jogo e a mesma porcentagem citou que não teve qualquer dificuldade em relação ao jogo.

Em relação às dificuldades e desafios propostos pelo jogo, a grande maioria dos estudantes de pós-graduação (42\%) citaram a dificuldade em entender o jogo, incluindo as regras de funcionamento, as possibilidades de ação e a dinâmica, depois que entenderam como o jogo funcionava, ficou fácil jogar. Incorporar o papel, o que significa pensar e agir como um dos atores da situação proposta também foi uma dificuldade sentida por $16 \%$ dos participantes, seguida da falta de tempo (13\%), da necessidade de negociar $(11 \%)$ e da tomada de decisões considerando o maior número de aspectos envolvidos (9\%). Apenas $7 \%$ dos jogadores disseram não ter tido nenhuma dificuldade com o jogo e $2 \%$ citaram a falta de conhecimento do assunto como uma das dificuldades.

As dificuldades do jogo são também exemplificadas nas frases dos participantes:

'No início as regras não ficaram claras, entendi a dinâmica depois da primeira reunião (do comitê) ...Tinha uma bomba no colo e não podia deixá-la cair! Tive que estudar para participar"

"No início por não entender as regras nem o meu papel no jogo, mas a partir da segunda rodada ficou cada vez mais claro"

"Apesar de achar que seria simples, me enganei e percebi que é muito difícil ser dona de certos lotes e saber utilizá-los corretamente, não esquecendo de preservar o meio ambiente, atender 'as minhas necessidades e as dos outrő̉

"Foi bastante angustiante, o município tinha muito pouco recurso financeiro, não tinha rede de esgoto e paralelamente, estava sendo invadido pelo movimento dos sem-teto."

“Incorporar o papel de proprietário e fazer negócios, sou péssima administradora de bens."

Verificamos que na pós-graduação houve maior dificuldade em entender o jogo do que na graduação, talvez pelo fato do público apresentar um conhecimento mais complexo 
sobre os conflitos relativos ao tema e estar de alguma forma mais ligado ao processo. Por outro lado, o público da graduação, por estar mais afastado da realidade, apresenta menor dificuldades em entender o jogo. No entanto, para tarefas mais complexas como negociar e tomar decisões os estudantes da graduação têm mais dificuldades.

Vale ressaltar ainda que apresentar dificuldades na primeira rodada, é comum a qualquer jogo, os participantes precisam de um tempo mínimo para entender as regras e a dinâmica do jogo.

Os comentários ressaltam também a distinção entre visões individuais e coletivas do problema, o jogo desperta emoções:'foi angustiante ", trazidas pela própria vivência de jogo e da possilidade de incorporar o papel e atuar plenamente na situação proposta.

Alguns estudantes tiveram maiores dificuldades para incorporar o papel, neste caso, informações complementares são fornecidas para facilitar a caracterização. Entretanto, esta estratégia não é viável para atores mais experientes como técnicos ou especialistas, pois pode direcionar demasiado as estratégias do jogador. Este é um dos aspectos que mostra como o público que participou das sessões não corresponde aos atores locais que por vivenciarem a situação diariamente, talvez estivessem mais familiarizados com a problemática. 


\section{- Aprendizados sobre recursos hídricos}

Figura 21 - Gráfico “Aprendizado sobre Recursos Hidricos”(Graduação e Pós -Graduação)

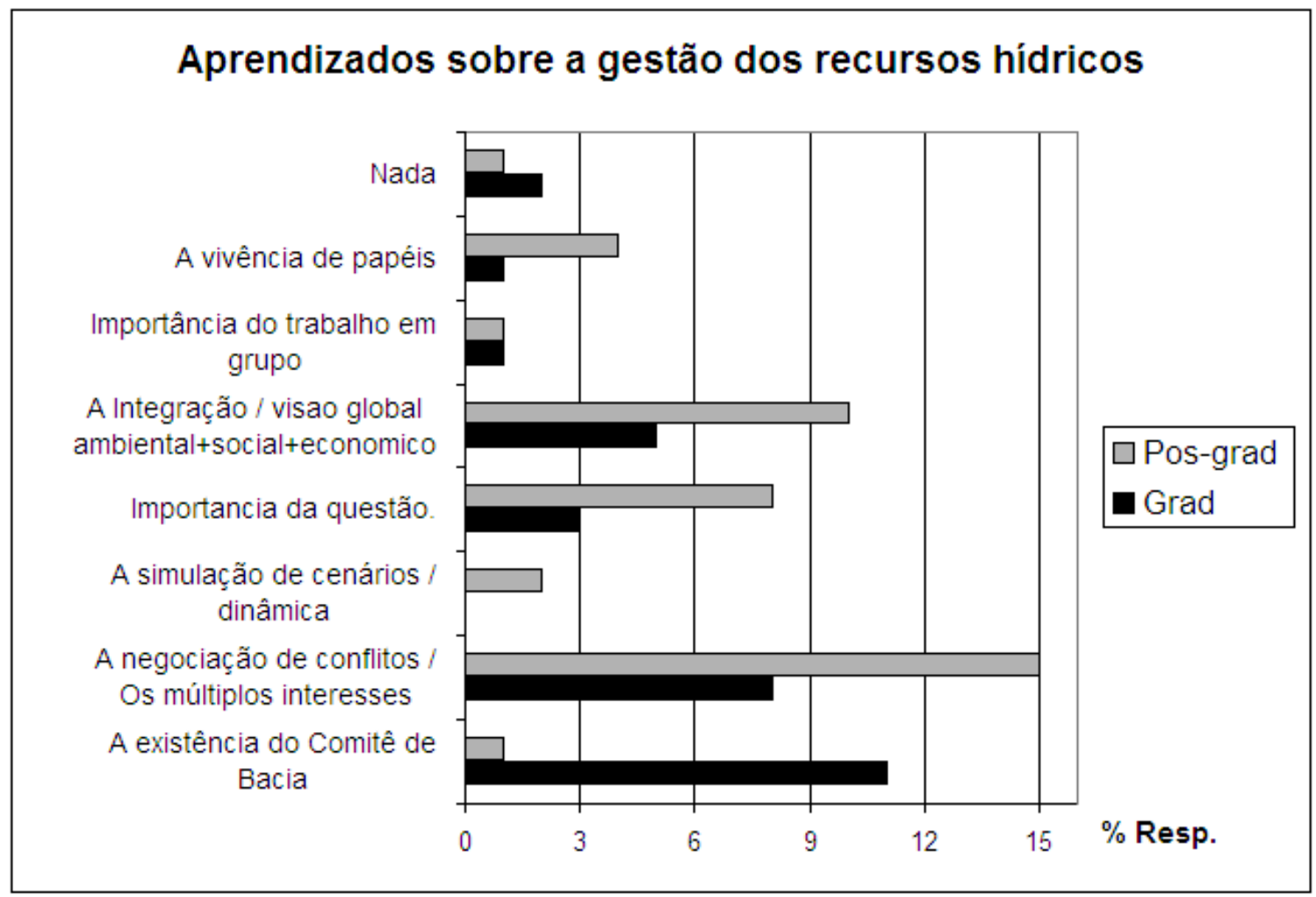

Fonte: elaborado pela autora.

Sobre o aprendizado proporcionado pelo jogo em relação à temática da gestão dos recursos hídricos, 36\% dos estudantes da graduação ressaltaram o conhecimento do Comitê de Bacia, órgão responsável pela gestão integrada, descentralizada e participativa dos recursos hídricos através do jogo. Em seguida, 26\% mencionou a necessidade de negociação devido à existência de múltiplos interesses em torno do mesmo recurso; $16 \%$ citou que o jogo possibilita uma integração dos vários fatores da realidade (aspectos social, ambiental e econômico) numa visão global da problemática.

Os estudantes da pós-graduação pareciam estar mais familiarizados com o tema da gestão dos recursos hídricos, uma vez que apenas $2 \%$ citou o conhecimento do Comitê de Bacia através do jogo. Ao contrário, $36 \%$ mencionaram a existência de múltiplos interesses em 
torno da questão e a necessidade de negociar, 24\% disseram ter aprendido sobre os diversos fatores da realidade que possibilitam uma visão global da questão e 19\% perceberam a importância e relavância da questão. A vivência de papéis foi um aprendizado do jogo citado em 10\% dos questionários respondidos e 5\% ainda mencionaram a simulação e a possibilidade de mudança de cenários, como importante na compreensão da dinâmica do processo. Trata-se de algo específico de um jogo com simulação informatizada, como o Jogo dos Mananciais (MAN).

Sobre os aprendizados em relação à gestão dos recursos hídricos numa bacia peri-urbana, citamos alguns dos comentários dos participantes:

"Aprendi que não é apenas instalar redes de saneamento, mas sim ter uma responsabilidade maior pois os recursos naturais não aumentam."

"Aprendi que cada aumento de povoamento e indústrias sem projetos, o tratamento fica mais difícil"

"Que a questão social tem muita importância" 


\section{- Aprendizados sobre negociação}

Figura 22 - Gráfico “Aprendizado sobre Negociação”(Graduação e Pós -Graduação)

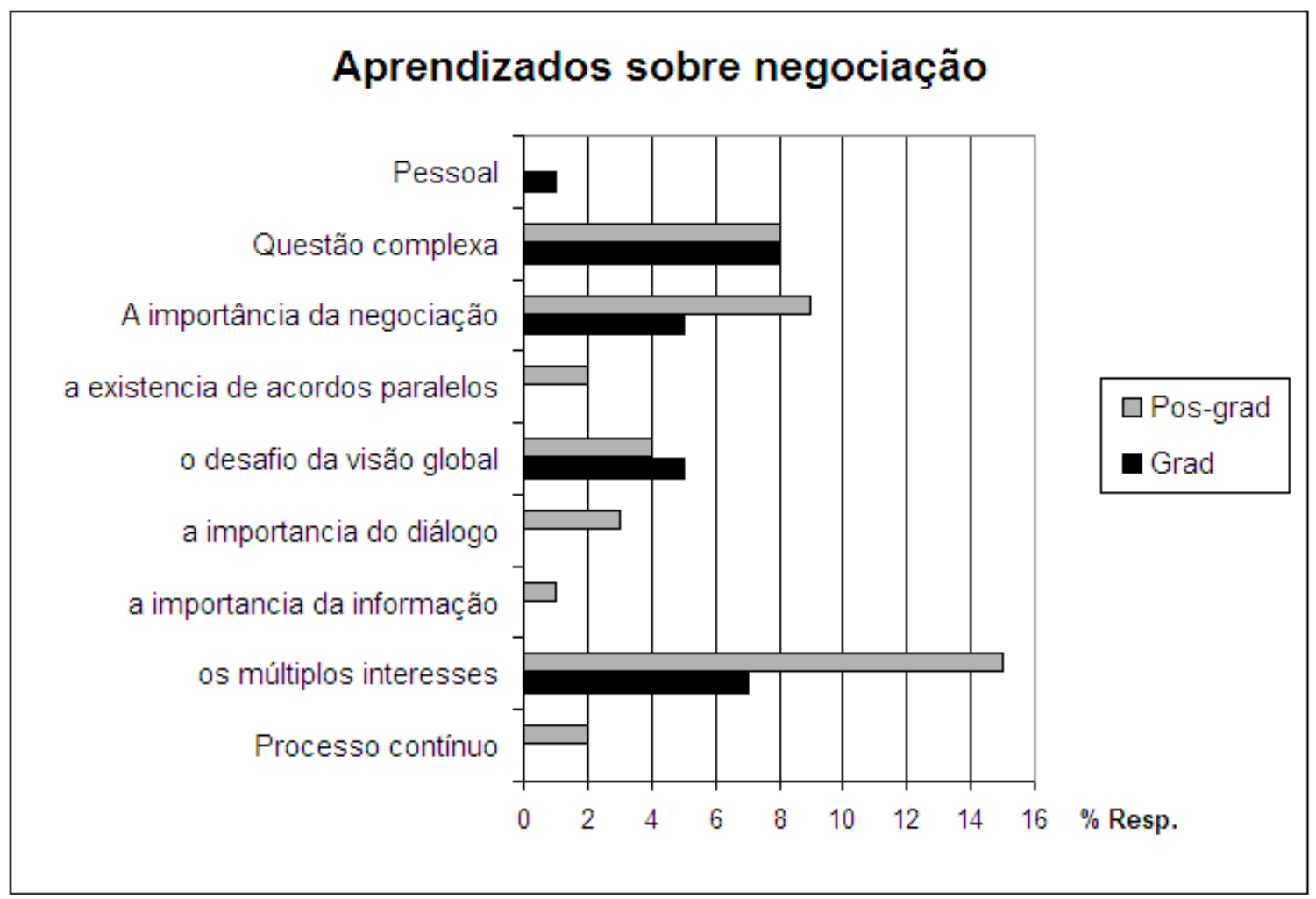

Fonte: elaborado pela autora.

Os estudantes de graduação perceberam através do jogo que a negociação é um processo bastante complexo (32\% apontaram a complexidade da questão), seguidamente, $28 \%$ indicaram a existência de interesses múltiplos no processo de negociação, 20\% apontaram o desafio da visão global, no que diz respeito aos obetivos mais coletivos em âmbito socioambiental e outros $20 \%$ dos participantes disseram perceber a importância da negociação na discussão da quastão dos recursos hídricos, especificamente no que concerne à problemática dos mananciais.

Os estudantes de pós-graduação perceberam, em sua maioria (34\%) os múltiplos interesses presentes no processo de negociação, $20 \%$ citaram a importância do processo e $18 \%$ notou a complexidade da questão. Com menos ocorrências foram registradas com 9\% o desafio da visão global, com 7\% a importância do diálogo e com 5\% a existência de acordos paralelos fora da negociação específica no Comitê de Bacia e também 5\% a negociação como um processo contínuo. 
A frase seguinte ilustra os aprendizados percebidos em relação à negociação de conflitos, construção de acordos e interações:

'Foi bom sentir na pele como é ser enganado, não me informar direito (ex: comprei terras que estavam sendo invadidas), a impotência diante de uma postura imprevista do prefeito e como é difícil ter uma visão global das coisas (ex:lucro com agricultura irrigada e qualidade da bacia)”

Percebe-se nos estudantes de graduação uma visão mais simplificada do processo de negociação, o que pode ser identificado pela menor diversidade de aspectos enumerados nas respostas, já o público de estudantes de pós-graduação apresenta uma visão mais complexa do processo de negociação, uma vez que os fatores e categorias citados adquirem maior variação nas respostas deste grupo. 


\section{- Aspectos da vivência de reunião do comitê de bacia}

Figura 23 - Gráfico “Vivência em reunião do Comitê de Bacia”(Graduação e Pós -Graduação)

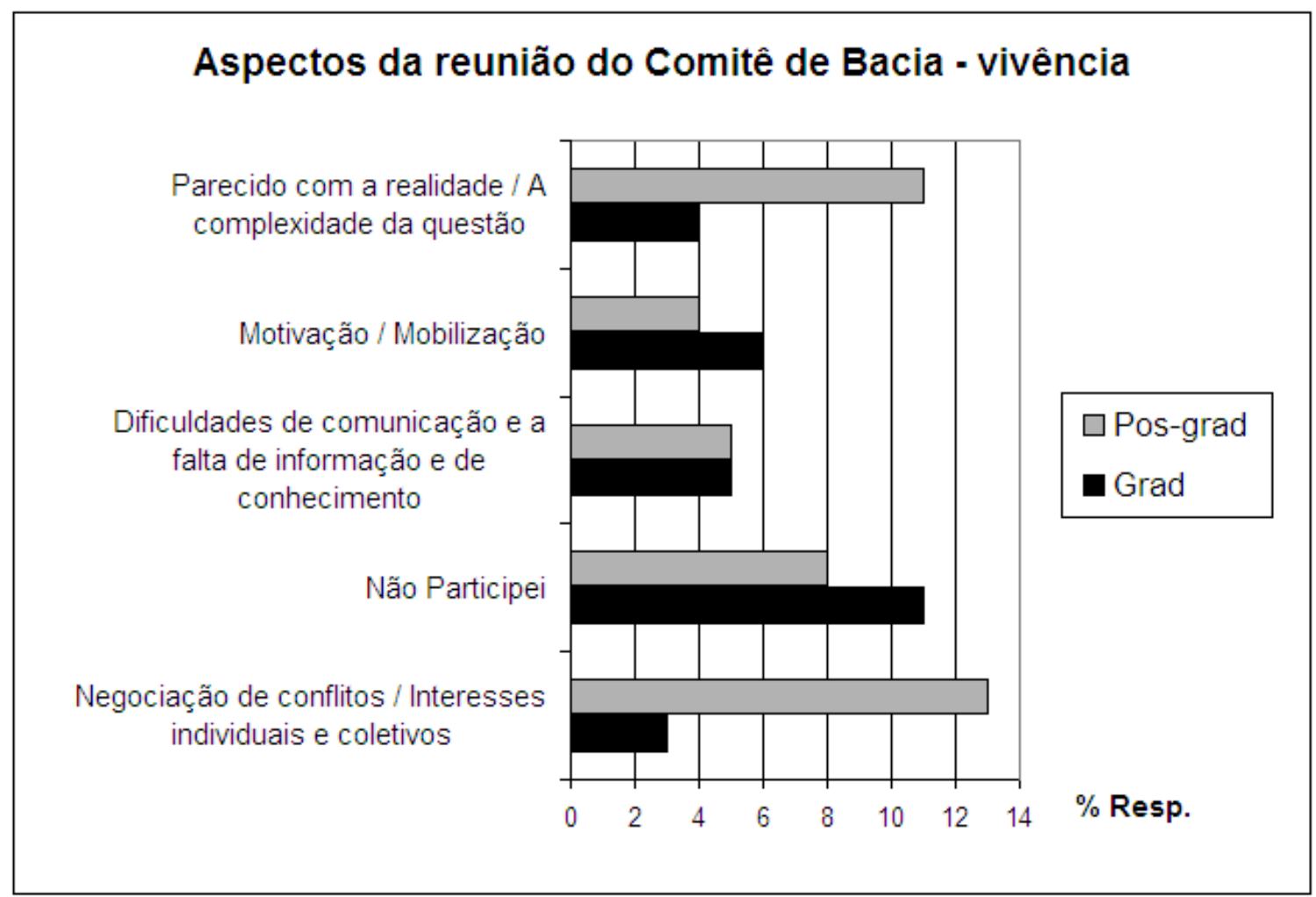

Fonte: elaborado pela autora.

Do grupo de estudantes de graduação, alguns admitiram que nunca tinham participado de uma reunião do comitê de bacia e, a partir do jogo, puderam ter uma idéia do funcionamento da mesma, o que foi positivo para estimular a participação e o conhecimento destes fóruns de discussão na temática da gestão dos recursos hídricos. No entanto, $38 \%$ dos jogadores disseram não ter tomado parte nas discussões da reunião simulada do Comitê de Bacia, ao passo que $21 \%$ manifestaram motivação e mobilização para participar da reunião e $17 \%$ citaram dificuldades de comunicação no fórum assim como a falta de informação e conhecimento necessários. Ainda neste grupo $14 \%$ citaram as semelhanças existentes com uma reunião de Comitê de Bacia verdadeira, principalmente no que concerne a complexidade das questões tratadas. 
Do grupo de estudantes de pós-graduação, $31 \%$ dos participantes disseram que durante a reunião foi necessário a negociação de conflitos, principalmente entre os interesses individuais e coletivos buscando acordos; $27 \%$ citaram as semelhanças existentes em relação à realidade; $20 \%$ disseram não ter participado diretamente da reunião do Comitê; $12 \%$ citaram dificuldades relativas à falta de comunicação e informação e $10 \%$ perceberam uma certa motivação e mobilização ao participarem da reunião do Comitê de Bacia. Exemplificamos a seguir o que mostram os gráficos com algumas frases dos participantes sobre a vivência de uma reunião do Comitê de bacia:

"A maior diferença é aprender na prática, fator importante que facilita o entendimento da

$$
\begin{array}{r}
\text { situação" } \\
\text { "Adrenalina e elucidativo" } \\
\text { "Foi uma experiência interessante, o 'fazer -de-conta'trouxe para o grupo a } \\
\text { oportunidade de se colocar no lugar do outro" }
\end{array}
$$

'Parecido com o que acontece na realidade: a velocidade da mudança na dinâmica das cidades, os interesses de cada participante e a diiculdade de pensar em algo comum” 'O que me chamou atenção foi perceber a imperfeição nas relações e acordos, sentir como em uma bacia ocorrem tantas mudanças em tão pouco tempo (de uma rodada para outra) e a necessidade de tomar decisões de forma rápida e muitas vezes sem muito embasamento, porque muita burocracia acaba deixando a questão em pauta desatualizada." 


\section{- Críticas e sugestões}

Figura 24 - Gráfico “Críticas e sugestões ao jogo”(Graduação e Pós -Graduação)

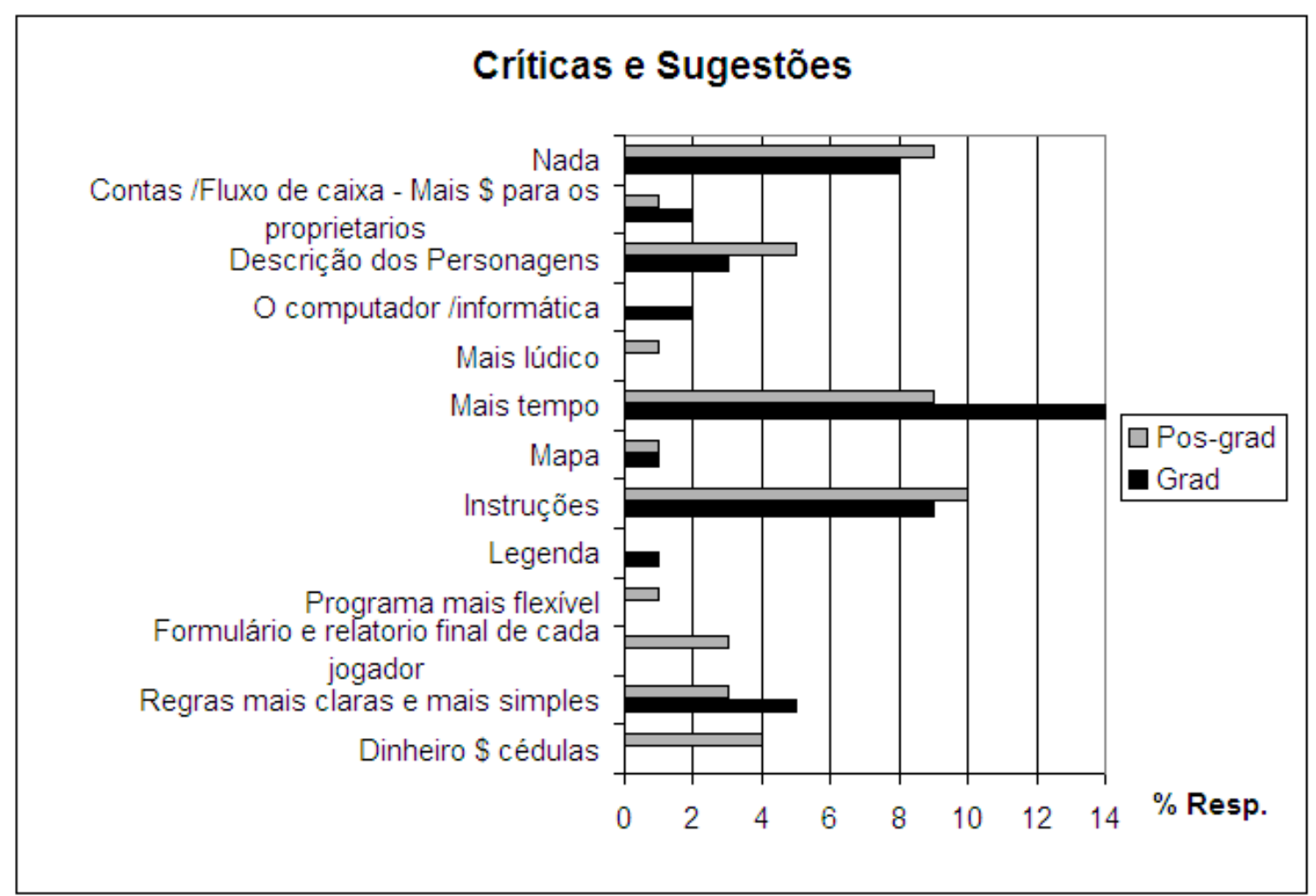

Fonte: elaborado pela autora.

As últimas questões dos questionários de avaliação versavam sobre as críticas e sugestões dos participantes em relação ao Jogo dos Mananciais. A quantidade de críticas e sugestões foi bastante elevada, destacamos aqui as que apareceram em maior número de ocorrências e as que foram consideradas de maior relevância para a análise do jogo.

A grande maioria dos estudantes de graduação (38\%) acharam que seria pertinente haver mais tempo de jogo, 24\% ressaltaram a necessidade de regras mais claras e instruções para o entendimento do jogo, todos afirmam que depois que entenderam a dinâmica do jogo, a discussão flui tranquilamente, ainda neste grupo, $14 \%$ citou a possibilidade de regras mais claras e mais simples que facilitassem a dinâmica de jogo.

As críticas e sugestões apontadas pelos estudantes de pós-graduação foram na mesma direção: instruções de jogo mais claras (25\%) e mais tempo de jogo(23\%), 13\% ressaltou 
ainda alterações na descrição dos personagens de jogo de forma a compreender melhor as características e personalidades de cada papel, $11 \%$ citou a possibilidade de cédulas representando dinheiro para facilitar a visualização.

As frases dos participantes trazem algumas das sugestões e críticas apontadas ao jogo:

'Regras mais claras, uma agenda didática para nos organizar melhor”

"Se o jogo será aplicado em diversos tipos de comunidade, co m alto, médio ou baixo grau de escolaridade, as dinâmicas de esclarecimento e propósitos do jogo precisariam ser mais clarificadas desde o início, mais didáticas.... Seria necessário ampliar o tempo para que houvesse momentos de reflexão conjunta do grupo sobre as dificuldades em cada etapa, para que as decisões fossem “amadurecendo”ao longo das sessões e, ao final, também houvesse mais tempo para a avaliação conjunta de todos os processos durante as dinâmicas, individuais e coletivas, contribuindo para ampliar a percepção da importância de se analisar posturas, hábitos, valores, políticas, interesses, enfim os fatores que podem facilitar ou dificultar a construção de processos integrados e participativos na gestão dos recursos hídricos."

"A falta de tempo, meio período é muito pouco tempo para um jogo dessa complexidade”

'O software é a grande novidade, ele nos mostra como ficariam os cenários de degradação da bacia caso os atores jogassem da forma como jogamos."

Alguns apontam ainda a necessidade de acessórios que tornem as ações mais concretas, menos abstratas, tais como cédulas de dinheiro ou "feijões" para simbolizar a venda de lotes, que poderia também servir para o controle do saldo de cada jogador.

De um modo geral, a grande maioria também mencionou o tempo escasso para um jogo tão complexo, quando estavam começando a entender, o tempo de jogo já se encerrava.

Alguns mencionaram a possibilidade de atribuir características mais pessoais e personalizadas aos atores no sentido de facilitar a incorporação do papel, no entanto, 
como verificado nos outros jogos estudados, isto pode também levar a estereótipos, reduzindo a possibilidade dos jogadores se projetarem no papel de acordo com suas representações sobre o papel.

Nas duas últimas sessões de jogo, houve a oportunidade de aplicarmos questionários iniciais aos participantes do jogo. Estes questionários tinham como objetivo verificar os conhecimentos prévios dos participantes em relação à temática dos jogos de papéis (RPG) e dos conflitos relativos à gestão dos recursos hídircos nas bacias peri-urbanas.

Apresentamos abaixo estes resultados como um complemento da análise, buscando perceber algumas diferenças sobre as impressões dos participantes antes e depois do jogo.

\section{- Grau de conhecimento dos jogos de papéis (RPG)}

Figura 25 - Gráfico 'Grau de conhecimento de jogos - RPG”

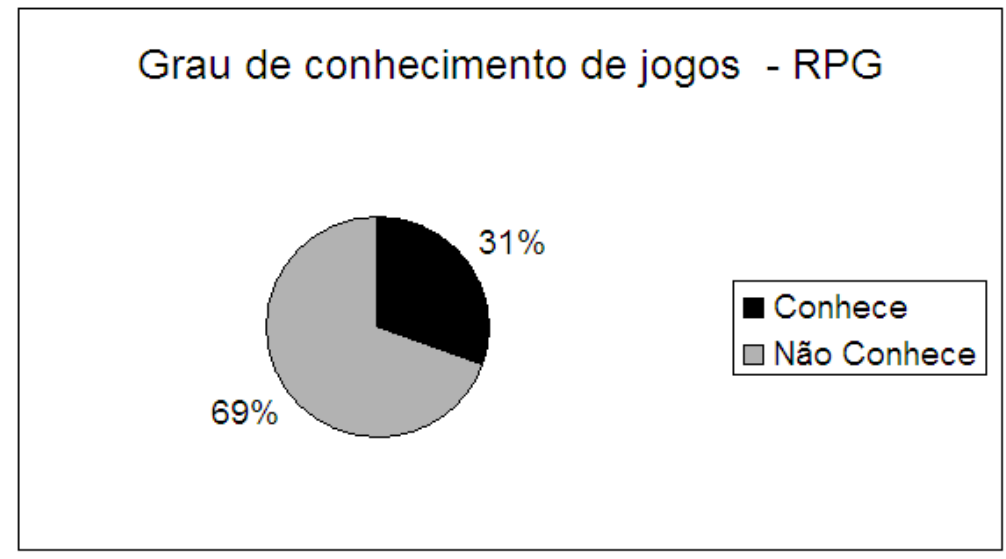

Fonte: elaborado pela autora.

Sobre o grau de conhecimento de jogos de papéis (RPGs), os estudantes em sua maioria não conheciam especificamente este tipo de jogos ou então nunca haviam jogado. Já $31 \%$ dos estudantes relataram alguns exemplos de jogos de papéis que tiveram contato. Dentre os exemplos citados apareceram: "Simulado de Conselho de Meio Ambiente", "Master", 'D\&D”, 'Vampiros”, 'Dragon Quest”, 'Magic', jog os famosos do universo do RPG. 


\section{- O que entende por jogo de papéis (RPG)}

Figura 26 - Gráfico 'O que entende por jogo de papéis - RPG"

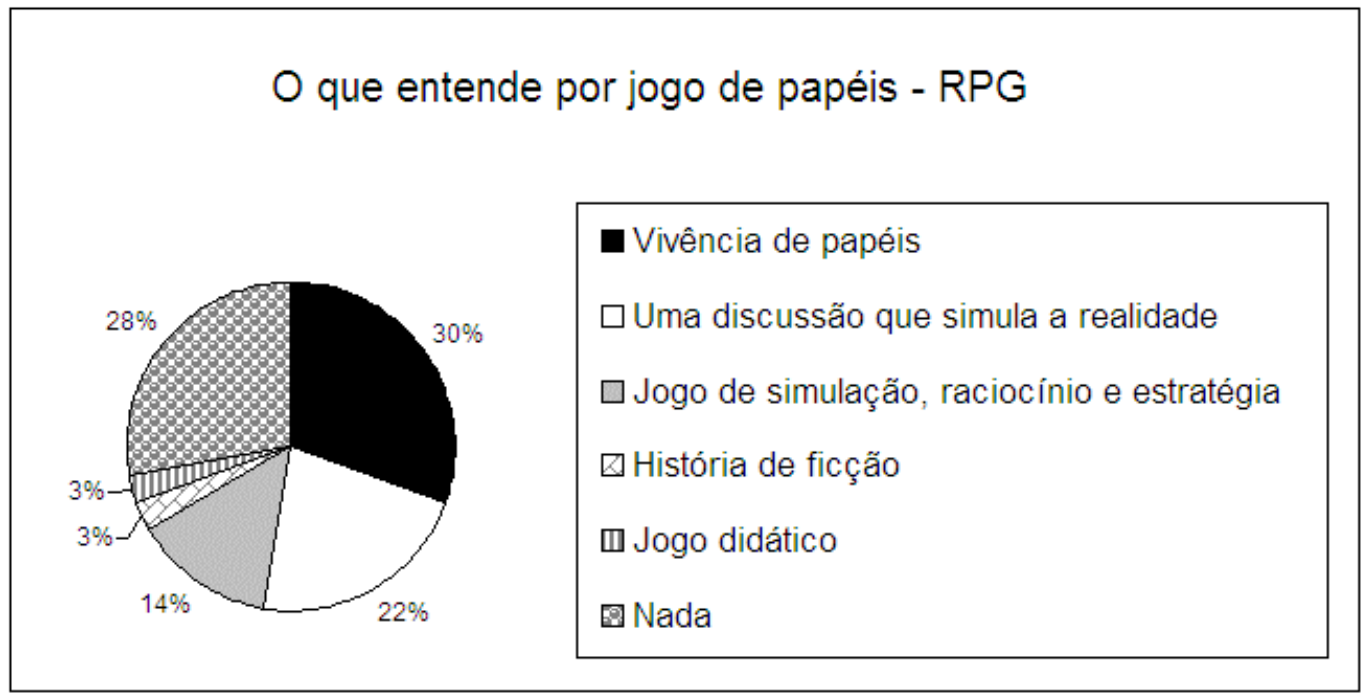

Fonte: elaborado pela autora.

Ainda neste questionário inicial, perguntamos o que os participantes entendiam por "jogos de papéis", os resultados aparecem a seguir. Nota -se como elementos principais citados a vivência de papéis, a simulação de uma discussão ou conflito da realidade, um jogo de simulação, raciocínio e estratégia. Um número significativo de participantes $(28 \%)$ disseram nada a respeito.

\section{- Expectativas}

Figura 27 - Gráfico 'Expectativas”

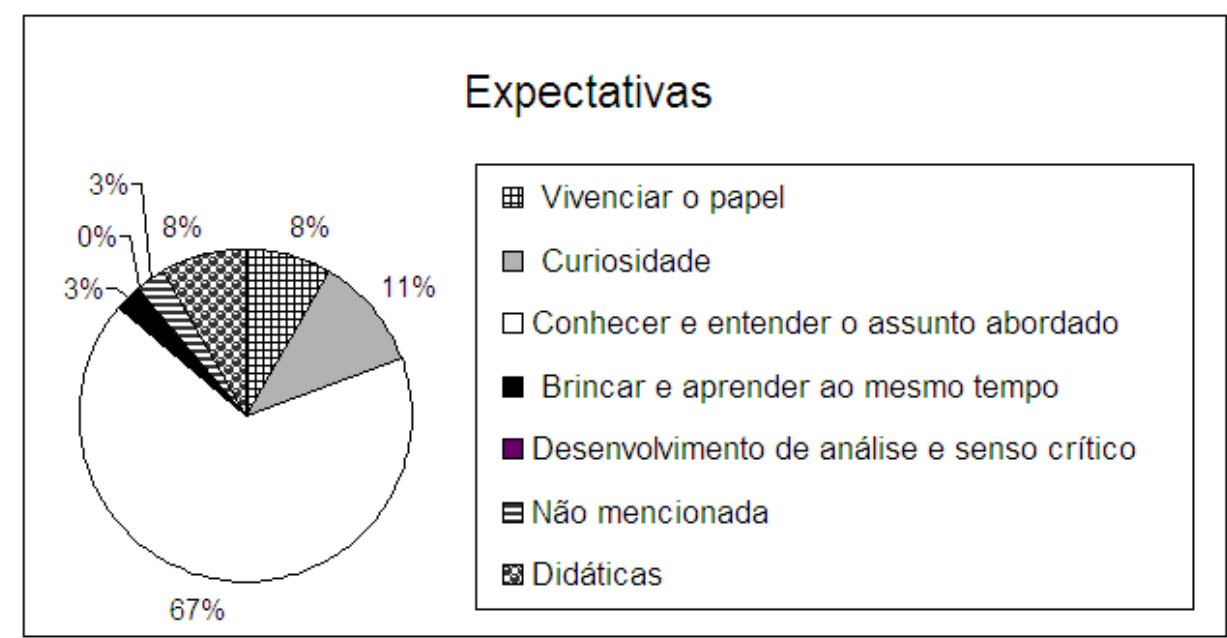

Fonte: elaborado pela autora. 
Em relação às expectativas dos participantes em relação ao jogo de papéis, aparecem conhecer o assunto, em grande maioria, seguido de curiosidade e da possibilidade de vivenciar o papel.

\section{- Conhecimento do Comitê de Bacia}

Sobre o grau de conhecimento do Comitê de Bacia, órgão responsável pelo gerenciamento participativo e integrado dos recursos hídricos, a relação é aproximadamente similar: $47 \%$ desconhecem a sua existência, enquanto $53 \%$ conhecem.

Figura 28 - Gráfico "Conhece o Comitê de Bacia"

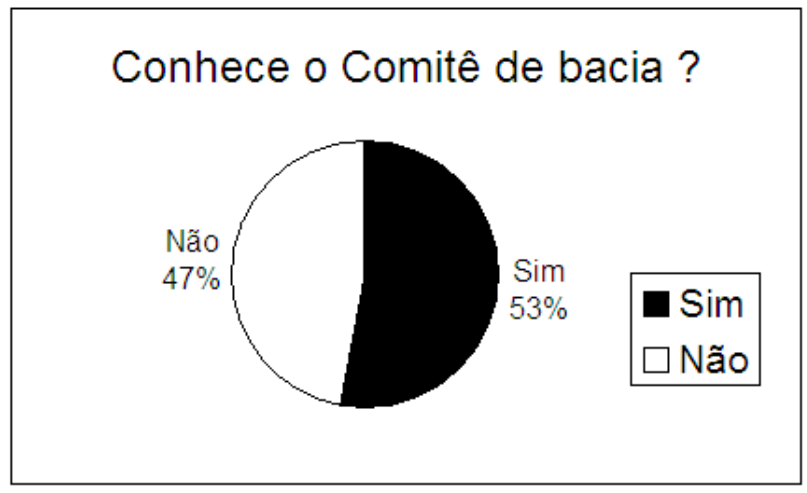

Fonte: elaborado pela autora. 
- Problemas da gestão dos recursos hídricos nas bacias peri-urbanas

Figura 29 - Gráfico "Problemas da gestão de Recursos Hídricos”

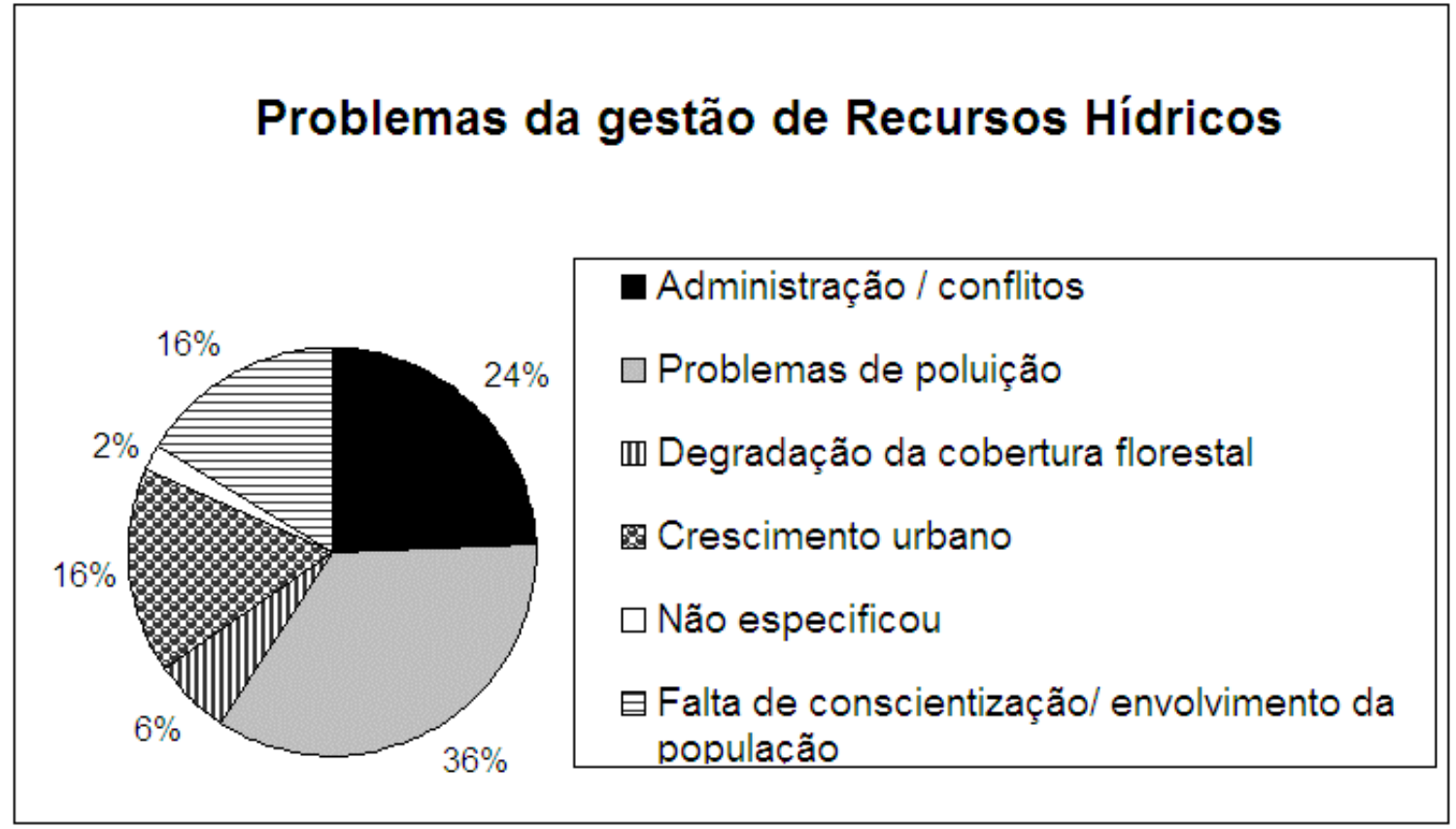

Fonte: elaborado pela autora.

Em relação aos conhecimentos prévios dos participantes em relação à problemática da gestão dos recursos hídricos, a maior parte aponta problemas de poluição das águas, problemas de administração das bacias hidrográficas e conflitos de conservação em relação à crescente ocupação. 
- Fatores de sucesso de uma negociação na área ambiental

Figura 30 - Gráfico 'Fatores de sucesso de uma negociação ambiental"

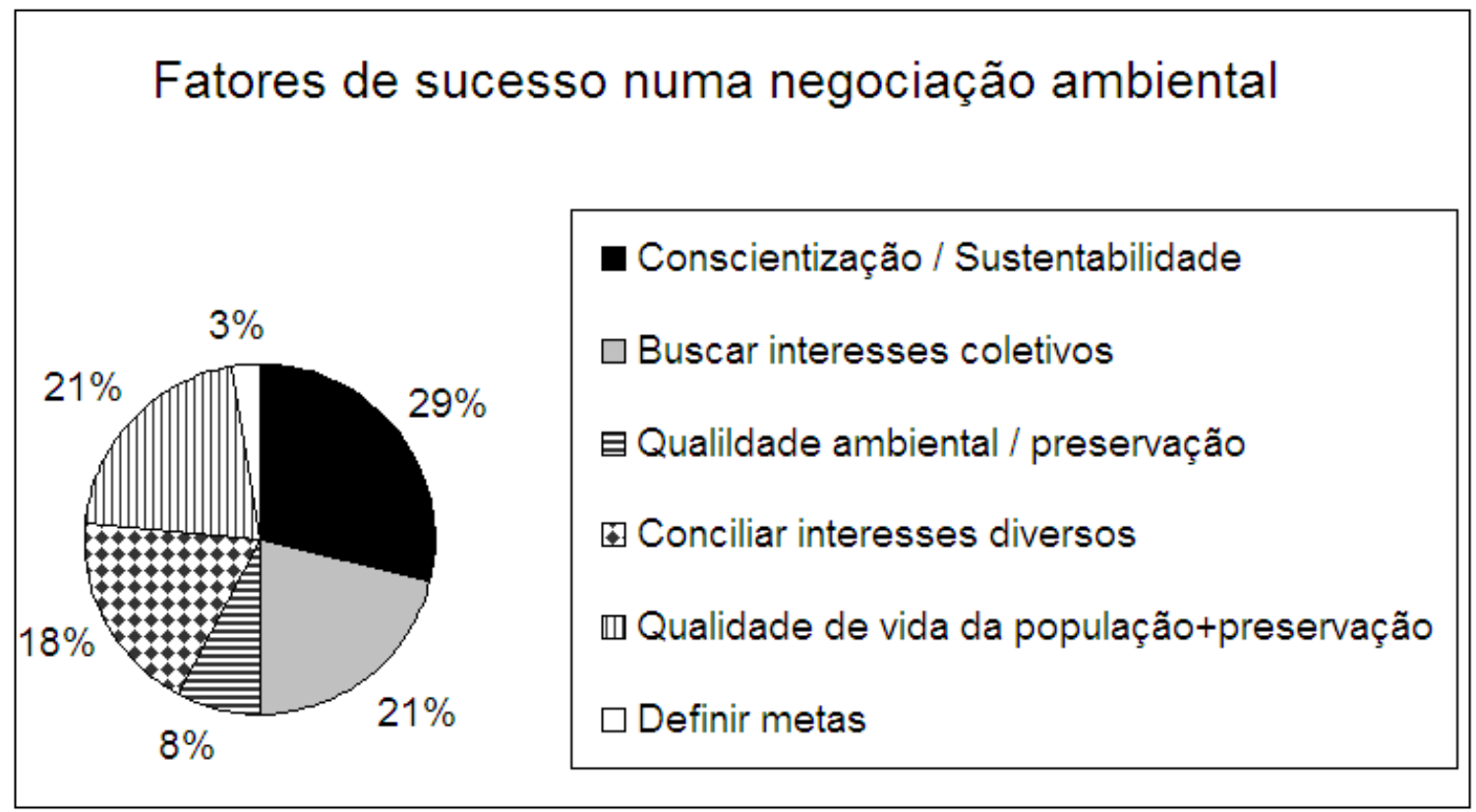

Fonte: elaborado pela autora.

Ainda sobre os conhecimentos prévios (questionário inicial) dos fatores de sucesso de uma negociação na área ambiental, os participantes citaram em primeiro lugar a conscientização sobre a problemática dos recursos hídricos, seguido da busca de interesses coletivos e do "respeito às comunidades locais", aliando a preservação à qualidade de vida. 


\subsubsection{Discussão : Possibilidades e limites de um jogo de papéis com simulação computadorizada}

Os pontos de discussão da análise do Jogo dos Mananciais em muito se assemelham aos tópicos levantados anteriormente na comparação dos vários jogos de papéis. Os aspectos comuns aos jogos de papéis já se apresentam contemplados acima e não vamos repeti-los nesta parte. $\mathrm{O}$ que trazemos aqui são alguns aspectos relativos às especificidades de um jogo de papéis com simulação computadorizada, neste sentido achamos pertinente considerar alguns tópicos nesta discussão.

Da mesma forma apresentada anteriormente, iniciamos a discussão pelas possibilidades deste tipo de ferramenta entendida como metodologia participativa de formação no âmbito da Educação Ambiental Crítica.

\section{- Possibilidades}

A explicitação da complexidade da situação através da visualização da mudança de cenários e da simulação

A visualização da mudança de cenários esclarece bastante sobre a complexidade da situação que envolve a rapidez da dinâmica de mudança, os acordos, as negociações, os interesses individuais sobre os coletivos, a falta de planejamento, a pressão urbana por moradia.

Nestes aspectos um jogo com um programa de simulação de cenários auxilia a explicitar a rapidez da alteração dos usos do solo numa área urbana de grande pressão por moradia, trazendo para o jogo muito da dimensão da realidade em questão. Na ausência do programa de computador seria muito mais difícil uma simulação de cenários que representasse bastante do que acontece na realidade.

A possibilidade de simular cenários esperados ou desejados pode também apresentar-se como um potencial recurso didático, os jogadores poderiam pensar em estratégias de ação, implementá-las e depois discutir os impactos gerados e o nível de conservação ou 
de degradação ambiental alcançado. Outros indicadores sociais disponibilizados no jogo também poderiam ser testados através da simulação de cenários. A aprendizagem seria bastante dinâmica e mais significativa à medida que as pessoas fossem verificando o impacto de suas ações na região onde se inserem.

\section{A possibilidade de integrar aspectos ambientais, sociais e econômicos numa} mesma plataforma de simulação

Os jogos de papéis tradicionais selecionados neste estudo já apresentam a capacidade de integrar os diversos aspectos de uma realidade e portanto conseguem explicitar a complexidade dos assuntos relativos à gestão socioambiental urbana.

No entanto, num jogo de papéis com simulação é possível visualizar a interação e as interrelações existentes entre os vários aspectos da realidade em questão. Num jogo com simulação, como o Jogo dos Mananciais, a pressão por moradia é nitidamente percebida pelos proprietários de terra, poder público, empresa de água enfim, por todos os agentes envolvidos na discussão em torno da problemática da bacia.

Neste sentido, jogos de papéis deste tipo explicitam a complexidade da situação, a medida que não abordam apenas os aspectos ecológicos ou naturais do problema, mas também os aspectos sociais, políticos e econômicos.

\section{- Limites}

Em relação aos limites apresentados por tais metodologias, também aparecem as que correspondem às especificidades destes jogos com simulação computadorizada

A necessidade de abstração por parte dos jogadores que pode traduzir-se numa dificuldade de entendimento do jogo

A representação do mapa de jogo de forma modelizada a partir de parcelas ou lotes representados por células já exige por parte de jogador um certo nível de abstração. Depois, à medida que o jogo vai se desenrolando, verificamos que é preciso uma certa lógica abstrata para compreender e visualizar as mudanças ocorridas no local a partir da 
visualização do mapa simulado. Este nível de abstração nem sempre é óbvio entre os participantes, e muitas vezes pode trazer dificuldades no entendimento e na própria dinâmica de jogo. O que talvez possa ser superado se os jogadores forem atores locais já familiarizados com a problemática e o jogo consiga trazer a discussão pertinente à realidade dos mesmos

\section{O público-alvo}

Um outro aspecto a ser considerado como um possível fator limitante deste tipo de jogos de papéis, que envolve simulação de cenários é o público-alvo a quem se destina.

Nesta primeira análise testamos o jogo com um público de estudantes universitários que de certa forma, já manifestaram algumas dificuldades no entendimento e na compreensão total do jogo. Ao longo dos testes percebemos que o jogo está afastado da realidade e apresenta uma visão acadêmica em relação aos conflitos de uso do solo e da água em regiões de mananciais peri-urbanos. No entanto, se for desenvolvido de forma mais próxima aos participantes, com um bom estudo de campo para aproximar-se bem da realidade em questão, a tendência será uma compreensão mais facilitada do jogo.

Se por um lado, as populações residentes em áreas de mananciais, temática do jogo, possuem uma visão mais próxima da realidade e uma maior clareza das questões inerentes à problemática, o fato de ser necessário um bom domínio de leitura e escrita para se conseguir jogar pode ser um fator limitante, é preciso encontrar alternativas de

apresentação do jogo e das fichas dos personagens que não necessitem de uma alta capacidade de leitura.

Neste caso, a presença fundamental do facilitador, como orientador e "mestre de jogo"é imprescindível. Considerar a formação de facilitadores para o desenvolvimento de um jogo como esse é algo que pode minimizar os problemas de compreensão do jogo pelas comunidades de baixa escolaridade e baixo grau de instrução.

É importante inserir um jogo de papéis com simulação num contexto de formação mais amplo, trabalhando as expectativas e dificuldades do grupo a cada momento. Materiais 
didáticos mais próximos como maquetes, cartazes, mapas podem ser úteis para introduzir o jogo, tornando-o mais inteligível para o público.

\subsection{CONSIDERAÇões RELEVANTES SOBRE OUTRO JOGO DE PAPÉIS COM ENFOQUE NA modelagem de aCompanhamento: O Processo Teraguas, Perspectivas do Projeto Negowat}

Como uma continuidade do processo iniciado com o Jogo dos Mananciais, buscando superar as dificuldades percebidas durante o processo e desenvolver um jogo de papéis realmente baseado na modelagem de acompanhamento, o Projeto Negowat está desenvolvendo um outro jogo de papéis, neste caso mais próximo à problemática local, levantada a partir de uma pesquisa diagnóstica e intitulado TerAguas.

O processo de construção do TerÁguas difere do Jogo dos Mananciais, por ter sido desenvolvido a partir de uma pesquisa com atores locais da região de Parelheiros, localizada na sub-bacia da Guarapiranga, bacia do Alto Tietê na região metropolitana de São Paulo. A pesquisa foi realizada no âmbito do Projeto Negowat pelo "Instituto Pólis"

- Instituto de Estudos, Formação e Assessoria em Políticas Sociais - organização não governamental (ONG) de referência, que desenvolve projetos sociais de apoio a políticas públicas e desenvolvimento local. O Instituto Pólis é uma das instituições parceiras do Projeto Negowat que atua diretamente na articulação e envolvimento dos atores locais. A pesquisa realizou-se com as associações de moradores do bairro de Parelheiros e a partir da devolutiva da mesma, foi organizado um grupo de trabalho e discussão local que serviu de base para a construção do processo TerÁguas.

O jogo faz parte de um processo mais amplo que compreende um processo de intervenção para a construção de um jogo de papéis em nível local sobre o uso e a ocupação da água e do solo na sub-bacia da Guarapiranga, SP. Deve-se ressaltar que a aplicação deste jogo de papéis ainda não havia sido realizada até a conclusão desta dissertação, no entanto, a trajetória de construção do jogo pode trazer diversos elementos fundamentais na análise das perspectivas dos jogos de papéis com enfoque da modelagem de acompanhamento e suas inflexões em relação à Educação Ambiental. 
Para a elaboração do jogo TerÁguas, foram somadas as representações locais provenientes da pesquisa com atores locais e as representações e dados dos pesquisadores envolvidos no projeto. Formou-se então um grupo de pesquisadores de diversas áreas tais como: ciências ambientais, ciências sociais, economia, hidrologia, saúde pública, agronomia, dentre outras que compuseram os indicadores do jogo, os atores importantes, os diversos usos do solo presentes na região e a situação-problema.

O processo de construção do Jogo TerÁguas foi dividido em duas etapas: na primeira fase houve reuniões com um grupo de pesquisadores das diversas áreas e instituições envolvidas no Projeto Negowat. Essas reuniões tiveram como objetivo a identificação dos atores essenciais e suas formas de interação, assim como a definição dos tipos de usos do solo possíveis de acordo com a escala de representação do modelo e dos conflitos em relação à ocupação do solo e da água abordados na região em questão. Um grupo mais específico, foi encarregado de definir e identificar a dinâmica dos recursos hídricos na área selecionada para o estudo.

$\mathrm{Na}$ segunda fase, um pequeno grupo aprimorou a modelagem de base focando especialmente na dinâmica de uso do solo, mudanças de usos do solo, aspectos fundiários e interações entre o uso do solo e da água. Nesta fase, foi analisado mais em detalhe os interesse potenciais de cada um dos grupos de atores, a definição da base espacial do jogo, dos jogadores, dos tipos de ações em detalhe e da concepção final do jogo.

A partir dessas discussões, foi elaborado um modelo informatizado que servirá de base para o jogo, desta forma, haverá a simulação de cenários a partir da implementação das ações dos jogadores. O processo TerÁguas prevê ainda uma primeira fase, anterior ao jogo com simulação computadorizada, em forma de maquete a fim de evidenciar os diferentes processos de poluição e integrar os atores locais na discussão relativa à problemática ambiental.

Atualmente o jogo TerÁguas está em fase inicial de teste, portanto o acompanhamento e a análise aprofundada das sessões não serão contemplados nesta pesquisa. 


\section{CONCLUSÕES E CONTRIBUIÇÕES DA PESQUiSA PARA NOVOS ESTUDOS}

Percebemos ao longo da pesquisa realizada, um grande potencial dos jogos de papéis para serem utilizados como ferramentas didáticas em projetos de Educação Ambiental.

Estes trazem diversas possibilidades que a vertente mais crítica da Educação ambiental apresenta como princípios. Um dos recursos deste tipo de ferramenta, é o potencial de integrar aspectos sociais, econômicos e ambientais, mostrando a complexidade da questão. Desta forma, ampliamos a discussão saindo de uma explicação mais conservacionista da questão ambiental para uma vivência mais reflexiva e crítica sobre o assunto abordado.

Conseguimos perceber através de um jogo de papéis que só o conhecimento técnico não basta para solucionar as questões socioambientais. É preciso negociar interesses e para isso, perceber os múltiplos interesses e pontos de vista envolvidos no processo. Neste sentido, o jogo de papéis pode ser também um bom instrumento de sensibilização, que traga um outro olhar sobre a problemática e os diversos pontos de vista dos atores mais envolvidos.

Por ser lúdico, o jogo desperta sentimentos que uma dinâmica de grupo comum ou uma reunião cotidiana de discussão podem não mobilizar. Ficamos surpresos com a disposição das pessoas para jogar novamente e continuar jogando quando o tempo acabava, isto é uma característica bem particular do jogo, dificilmente verificada em outras dinâmicas de grupo. À medida que as pessoas entendiam melhor as regras do jogo e tinham maior domínio sobre a situação proposta estavam dispostas a continuar jogando para melhorar as suas ações, talvez neste sentido estejam os aspectos competitivos inerentes mesmo num jogo cooperativo, a vontade de superar a si mesmo, sendo o jogo um exercício para tal prática. Talvez esta disposição para jogar seja também um traço da cultura do povo brasileiro que gosta do jogo, de uma maneira geral.

Isto aliado à possibilidade de vivência de um personagem mobiliza as pessoas, e pode ser muito útil para desenvolver uma certa empatia, que consiste na capacidade de se colocar 
no lugar do outro, percebendo os seus pontos de vista e as perspectivas dos outros agentes envolvidos no processo. O jogo ainda é capaz de explicitar fatores básicos da negociação como a existência de múltiplos interesses que nem sempre correspondem ao papel definido de cada agente. De acordo com o nível de complexidade do jogo de papéis, a negociação de conflitos proposta pode ser mais ou menos próxima à realidade, dependendo da interação e da interdependencia de fatores que se pretenda explorar.

Os jogos de papéis, desde os tradicionais utilizados em projetos de formação até os que apresentam algum tipo de simulação de cenários são metodologias didáticas em potencial, à medida que, possibilitam uma discussão coletiva e uma troca de visões e representações sobre uma mesma realidade.

As possibilidades destas metodologias são grandes, no entanto, seus limites também o são. O entendimento do jogo pode se tornar um fator limitante se não forem criadas condições de mediação que facilitem o processo e que estejam adaptadas ao público a quem se destina.

A simulação de cenários num jogo de papéis informatizado impõe alguns limites óbvios no que concerne ao equipamento necessário e aos conhecimentos básicos de interpretação de legendas e gráficos que nem sempre estão disponíveis à grande maioria da população.

No entanto, tais obstáculos podem ser facilmente superados, se os facilitadores ou educadores desenvolverem um trabalho de formação voltado às necessidades e demandas do público, reconhecendo os limites e superando as dificuldades, num processo mais longo e continuado de Educação Ambiental.

Os jogos de papéis selecionados neste estudo apresentam uma preocupação de estarem sempre vinculados a um curso ou projeto de formação mais amplo e, neste sentido, as suas características educativas e promissoras podem ser potencializadas.

Em relação a uma educação para a participação, que busque formar membros da sociedade civil para entender melhor assuntos técnicos e participar de forma mais qualificada dos fóruns específicos, o jogo de papéis pode ser um potencial instrumento. 
Neste contexto, os jogos de papéis aparecem como uma ferramenta didática de formação que, além de permitir um maior conhecimento técnico sobre os conflitos, podem promover também um aprendizado social sobre os processos de negociação inerentes à mobilização dos atores envolvidos no processo, a fim de potencializar a sua participação.

Verificamos que é necessário haver um equilíbrio constante entre o nível de complexidade e a inteligibilidade do jogo, quanto mais complexos são os processos do jogo, a dinâmica e a compreensão por parte dos participantes acaba ficando comprometida.

Uma das possibilidades para superar tal obstáculo, seria a participação dos atores durante todo o processo de elaboração do jogo. Desta forma, os jogadores tomariam parte na elaboração das regras e na construção do jogo de forma bem participativa, assim, certamente as dificuldades de compreensão seriam minimizadas, uma vez que, as informações, regras e toda a dinâmica do jogo seriam definidas previamente pelos próprios jogadores, de forma que haveria uma apropriação da situação proposta.

Ainda sobre a questão do entendimento do jogo, e por toda a sua complexidade, os jogos de papéis, principalmente os que envolvem a modelagem multi-agente devem prever uma formação de multiplicadores. No processo de aplicação do jogo, a formação de educadores ambientais deve também ser contemplada, uma vez que, tais metodologias, mais do que um instrumento direto de intervenção na comunidade local, precisam de um mediador, que seria o educador ambiental e estaria apto a potencializar a discussão esclarecendo as dúvidas sobre o funcionamento e a dinâmica de jogo.

O tempo dedicado e o esforço necessário à elaboração de um jogo de papéis, seja este tradicional ou pautado na modelagem de acompanhamento, é por vezes excessivo, o que nos leva a considerar a pertinência e a relevância do uso de tais ferramentas em processos de curta duração e, sobretudo, nos quais o público-alvo não se constitui como atores locais. No caso do público acadêmico, especialmente os da graduação, que corresponde a um público não tão próximo à realidade da problemática da gestão dos recursos hídricos, em particular dos mananciais, o alcance de um jogo de papéis ou de uma ferramenta de 
tal complexidade parece limitado. Já para os estudantes de pós-graduação em cursos da área ambiental, que estão mais próximos da discussão de tal problemática, o jogo de papéis teria maior alcance.

Vale lembrar que ao fim desta pesquisa fica a conclusão de que o jogo de papéis pode ser uma potencial metodologia ou ferramenta didática de educação ambiental por todas as características e possibilidades que apresenta. Entretanto como qualquer outra ferramenta didática sempre será apenas uma metodologia e, como tal, deve estar integrada num processo de formação continuada que contemple os princípios de uma educação problematizadora, pautada na troca e no diálogo, que respeite as diferenças e, sobretudo, acredite na possibilidade de cada educando como sujeito de transformação do seu ambiente. O jogo de papéis deve ser entendido como uma atividade-meio, complexa e com toda a sua amplitude, mas que não pode se encerrar em si mesma. Desta forma, deve estar sempre embasada por um objetivo maior do que se pretende despertar nos educandos, pautada numa intencionalidade e inserida num contexto.

Esperamos que esta pequisa seja uma contribuição à realização de trabalhos posteriores sobre o tema, uma vez que a análise de metodologias e ferramentas didáticas, de um modo geral, ainda é limitada na área da Educação Ambiental.

Com as mais recentes conquistas no campo da gestão dos recursos hídricos, como a publicação da Lei específica da Guarapiranga (Lei $\mathrm{n}^{\circ}$ 12.233, de 16 de janeiro de 2006) pelo governo do Estado que define estabelece zonas de ocupação dirigida e de restrição à ocupação de acordo com o diagnóstico local, a população residente nesta área deverá participar ativamente da discussão e do planejamento urbano da região. Para tanto é necessário uma formação e um envolvimento dos vários segmentos da sociedade civil, principalmente os de baixa renda, que constituem grande parte da população local.

Da mesma forma, a Cobrança pelo uso da água (Lei no 12.183 de 29/12/2005) exige uma discussão ampla que envolve todos os usuários na gestão dos recursos hídricos e não pode estar restrita apenas alguns setores. 
Metodologias participativas apresentam bastante relevância no cenário atual principalmente na gestão dos recursos hídricos, esperamos que sirvam de apoio à negociação de conflitos e que sejam integradas num processo de Educação Ambiental, contribuindo para uma participação mais qualificada dos movimentos da sociedade civil, de forma que estes possam dicutir ativamente e participar em condições de equidade nos fóruns específicos. 
8. APÊNDICES E ANEXOS 


\subsection{EDUCAÇÃo AMBIENTAL, UM BREVE HISTÓRICO}

A Educação ambiental (EA) foi um conceito que sutilmente começou a ser incorporado pelo movimento ambientalista na temática ambiental a partir de 1968 no "Clube de Roma”. Nesta reunião, vários cientistas dos países desenvolvidos preocupados com as reservas naturais e o crescimento da população mundial apontavam a necessidade de se investir numa mudança radical na mentalidade de consumo e procriação, afirmavam que “o homem deve examinar a si próprio, seus objetivos e valores” (REIGOTA, 1994).

O Clube de Roma, com a publicação 'Os Limites do Crescimento “, colocou então o problema ambiental em nível planetário e conseqüentemente, a ONU - Organização das Nações Unidas organizou a Primeira Conferência Mundial de Meio Ambiente Humano em 1972. Este grande evento, realizado em Estocolmo na Suécia, teve como um dos temas principais de discussão a poluição industrial e as consequiências da industrialização principalmente nos países em desenvolvimento como o Brasil.

Posteriormente, em Belgrado na Iugoslávia, houve uma reunião de especialistas de diversas áreas para a definição dos objetivos da Educação Ambiental no ano de 1975. O documento elaborado ficou conhecido como a "Carta de Belgrado", o qual enfatizava os seguintes princípios da EA: 1) a conscientização sobre os problemas ambientais, 2) o conhecimento relativo à compreensão do meio ambiente global, 3) a mudança de comportamentos e valores, 4) a competência técnica necessária à resolução dos problemas ambientais, 5) a capacidade de avaliação de programas ambientais a partir do entendimento da linguagem técnico-científica utilizada pelos especialistas e 6) a participação das pessoas para a construção de uma cidadania ativa (REIGOTA, 1994).

Em 1977, foi realizado o Primeiro Congresso Mundial de Educação Ambiental em Tbilisi, na Geórgia. Este adotava um discurso bastante semelhante ao da Carta de Belgrado, enfatizando a perspectiva interdisciplinar, como pode ser verificado a seguir: 
"Ao adotar um enfoque global, sustentado em uma ampla base interdisciplinar, a EA cria uma perspectiva dentro da qual se reconhece a existência de uma profunda interdependência do meio natural com o meio artificial, demonstrando a continuidade dos vínculos dos atos do presente com as consequiências do futuro, bem como a interdependência das comunidades nacionais e a solidariedade necessária entre os povos" (Declaração da Conferência Intergovernamental de Tbilisi sobre EA, 1977 apud CASCINO,1999).

Dos princípios básicos da EA discutidos em Tbilisi, Dias destaca o entendimento das múltiplas dimensões do meio ambiente (econômica, social, tecnológica, política, histórica e cultural); o desenvolvimento de um processo contínuo e permanente em todos os níveis de ensino formal e não - formal; o enfoque interdisciplinar para uma visão global e a complexidade das questões ambientais (DIAS,1992):

No Brasil é instituída, em 1981 a Política Nacional de Meio Ambiente através da Lei 6938 de 31/08/1981, que em seu artigo $2^{\circ}$, inciso X destaca a promoção da EA em todos os níveis de ensino, inclusive a educação da comunidade objetivando capacitá-la para a participação ativa na defesa do meio ambiente. Alguns anos mais tarde, a própria Constituição federal de 1988 reforça a importância da EA. Em seu Capítulo VI - Do meio ambiente, Artigo 225, inciso VI: promover a EA em todos os níveis de ensino e a conscientização pública para a preservação do meio ambiente (SORRENTINO, 1998).

No âmbito internacional, em 1987 realiza-se o $2^{\circ}$ Congresso Internacional de treinamento e Educação Ambiental em Moscou, reunindo 300 especialistas de mais de 100 países para discutir os avanços e dificuldades da EA naquele momento. Este encontro veio reforçar os princípios de Tbilisi, considerando que a EA deve enfatizar a abordagem de resolução de problemas ambientais relacionados à comunidade com enfoque interdisciplinar (DIAS, 1992).

Em 1988, a UNESCO através do Programa das Nações Unidas para o Meio Ambiente (PNUMA) organiza um Seminário Latino Americano de Educação Ambiental com recomendações especificas para a América Latina. Deste encontro surgiu a necessidade de elaborar um Manual latino-americano de Gestão ambiental com a comunidade. Depois de várias dificuldades, o Conselho de Educação de Adultos da América Latina, através de 
seu Programa de Educação Popular Ambiental, encarregou-se de desenvolver o material (VIEZZER, 1994).

$\mathrm{Na}$ década de 90, com a Conferência Internacional sobre Meio Ambiente e Desenvolvimento da ONU, no Rio de Janeiro, em 1992 (Rio-92), é elaborado o "Tratado de Educação Ambiental para Sociedades Sustentáveis e Responsabilidade Global”, durante o II Fórum de EA. O documento citado considera a EA como um processo de aprendizagem permanente, uma educação que afirma valores e ações que contribuem para a transformação humana e social e para a conservação ecológica (CASCINO,1999).

Leonardi destaca um dos princípios do Tratado, o qual afirma que a EA deve ser "crítica e inovadora e que não é neutra, mas sim um ato político voltado para a transformação social" (LEONARDI, 1996). O Tratado de EA entende a problemática ambiental como resultante de uma crise não apenas ambiental, mas também civilizatória, incluindo as questões sociais, causadas por um desenvolvimento insustentável que não tem considerado a finitude e a escassez dos recursos naturais.

Ainda na Rio-92, há uma reorientação da EA para o desenvolvimento sustentável com as orientações de promover a conscientização popular e o treinamento. Na elaboração do documento da Agenda 21, a EA aparece em quase todos os capítulos, com o destaque para o Capítulo 36.3, que diz que para ser efetiva, a EA deve lidar com as dinâmicas físico-biológicas e socioeconômicas do ambiente e do desenvolvimento humano (DIAS, 1992).

Em 1994 é aprovado o PRONEA - Programa Nacional de EA - que vem a ser instituído somente em 1999 com a aprovação da Lei 9597 / 99 que institui a Política Nacional de EA e mais tarde, em 2002, o decreto 4281 regulamenta tal legislação. Da primeira destacamos a seguir os dois primeiros artigos que definem a EA:

Art. $1^{\underline{o}}$ Entendem-se por educação ambiental os processos por meio dos quais o indivíduo e a coletividade constroem valores sociais, conhecimentos, habilidades, atitudes e competências voltadas para a conservação do meio ambiente, bem de uso comum do povo, essencial à sadia qualidade de vida e sua sustentabilidade. 
Art. $2^{\underline{0}}$ A educação ambiental é um componente essencial e permanente da educação nacional, devendo estar presente, de forma articulada, em todos os níveis e modalidades do processo educativo, em caráter formal e não-formal.

Em 1999, o tema "Meio Ambiente" é incluído, pelo MEC, como tema transversal nos Parâmetros Curriculares Nacionais (PCNs). Alguns consideram tal proposta um avanço, embora, segundo Reigota, este tenha sido um projeto elaborado por especialistas sem a participação dos educadores que já participavam do processo histórico de construção das teorias e práticas da EA (REIGOTA, 1999). 


\subsection{ROTEIRO DE QUESTÕES PARA ENTREVISTA COM AUTORES DOS JOGOS SELECIONADOS}

Nome do jogo

Autores

Ano de publicação

O Material de jogo

Quem desenvolveu? Por quê? Qual foi a demanda? Como foi o processo?

A aplicação e testes do jogo

Como o jogo foi utilizado? Com que público? Como este foi selecionado?

O jogo no processo de formação

Especificar os objetivos do jogo

O processo de jogo - Dinâmicas, regras, papéis

Avaliação final do jogo- Como é realizada?

Quais os maiores problemas e desafios encontrados no jogo desenvolvido?

Como vê o jogo de papéis no processo de participação e mobilização popular?

Como vê o jogo de papéis (RPG) na Educação Ambiental? 


\subsection{QUeSTIONÁRIOS Jogo dos MANANCIAIS}

Nome e-mail

1. Ficou satisfeito (a) com o jogo? Gostou de jogar? Por quê? As suas expectativas foram alcançadas?

2. Gostaria de jogar ou trabalhar com esse grupo de novo? Por quê?

3. O que você aprendeu de novo no jogo em relação à gestão dos recursos hídricos?

4.O que você aprendeu de novo no jogo em relação às interações com os outros e à construção de acordos?

5.Quais foram as suas maiores dificuldades? Foram resolvidas ao longo do jogo? De que forma?

6. Como foi participar de uma reunião do "Comitê de Bacia'?

7.O que você mudaria no material de jogo?

8.Para você, o que o jogo trouxe de diferente de outras dinâmicas de grupo como grupo focal, aulas, debates, palestras, etc ? Dê suas críticas e esugestões. 
Nome e-mail

1. Você conhece algum jogo de papéis (RPG)? Qual? Já jogou?

O que você entende por jogo de papéis?

2. Quais são as suas expectativas em participar dessa sessão de jogo? Explique.

3. Na sua opinião, quais são os maiores problemas da gestão dos recursos hídricos nas bacias peri-urbanas? Especifique.

4. Você conhece o papel dos Comitês de Bacia? Como?

5. Para você quais são os fatores de sucesso de uma negociação na área ambiental? 


\section{REFERÊNCIAS BIBLIOGRÁFICAS}

ALVES, A. J. (1991) O Planejamento de Pesquisas Qualitativas em Educação Faculdade de Educação/ UFRJ Cadernos de Pesquisa, São Paulo 77, p. 53-61.

ANCONA, A.L.(2002) Direito ambiental, direito de quem? Políticas públicas do meio ambiente na metrópole paulista. São Paulo, Tese de doutorado: FAU-USP

ARNSTEIN, S. (1969) Uma escada da participação cidadã. Traduzido por Markus Brose. Journal of the American Planning Association. "A ladder of citizen participation", v. 35, n. 4 , p.216-224

AVANZI, M.R. (2004) Ecopedagogia. In: LAYRARGUES, P.P. (coord) Identidades da educação ambiental brasileira. Brasília, MMA. 156p.

AZEVEDO, L.G.T.et al. (2003) Água, Redução da pobreza e desenvolvimento sustentável. Brasília. Banco Mundial (Série Águas Brasil)

BARBIER, R.(2002) A pesquisa-ação. Brasília, Plano Editora. 159p. (Série pesquisa em educação, v. 3).

BARRETEAU, O. (2003) The joint use of role-playing games and models regarding negotiation processes: characterization of associations. Journal of Artificial Societies and Social Simulation, U.K., v.6, n. 2.

BARRETEAU, O. et al (2003) Our Companion Modelling Approach. Journal of Artificial Societies and Social Simulation, U.K.,v.6,n.1,p.1-6.

BARRETEAU, O.; BOUSQUET, F.; ATTONAY, J.M. (2001) Role-playing games for opening the black box of multi-agent systems: method and teachings of its application to Senegal River Valley irrigated systems. Journal of Artificial Societies and Social Simulation, U.K., v.4, n. 2.

BIDERMAN, C. (2001) Forças de atração e expulsão na grande São Paulo. São Paulo, Tese de doutorado Fundação Getúlio Vargas (FGV)

BOISSAU, S; CASTELLA,J.C.(2003). Constructing a common representation of local institutions and land use systems through simulation-gaming and multiagent modeling in rural areas of Northern Vietnam: The SAMBA-Week methodology. Simulation \& Gaming, [S.I.],v.34,n.3,p.342 - 357

BRANDÃO, C.R. (1995) Em campo aberto: escritos sobre a educação e a cultura popular. São Paulo, Cortez, 229p.

BRANDÃO, C.R. (1981) Pesquisa participante. São Paulo, Brasiliense. 
BROTTO, F.O. (2001) Jogos cooperativos: o jogo e o esporte como um exercício de convivência. Santos, Projeto Cooperação.

BROSE, M. (org) (2001) Metodologia participativa: uma introdução a 29 instrumentos. Porto Alegre, Tomo Editorial. 312p.

CAILLOIS, R. (1958) Os jogos e os homens. Lisboa, Ed. Cotovia, 1990.228p.

CARVALHO, I.C.M. (2004) Educação Ambiental Crítica: idéias para este outro mundo possível In: LAYRARGUES, P.P. (coord) Identidades da educação ambiental brasileira. Brasília, MMA. 156p.

CARVALHO, I.C.M. (2002) O "ambiental"como valor substantivo: uma reflexão sobre a identidade da educação ambiental. In: SAUVÉ, L.; ORELLANA, I.; SATO, M. Textos escolhidos em Educação Ambiental: de uma América à outra. Montreal, Publications ERE-UQAM, Tomo I, p.85-90

CARVALHO, I.C.M. (1998) Em direção ao mundo da vida: interdisciplinaridade e educação ambiental. Brasília, IPÊ - Instituto de Pesquisas Ecológicas.102p.

CASCINO, F. (1999) Educação ambiental: princípios, história, formação de professores. São Paulo, Senac.

CATUNDA, C. (2000) Conflitos da expansão urbana na Bacia Hidrográfica de Guarapiranga: a ocupação urbana e o papel desempenhado pelos instrumentos de planejamento urbano ambiental na configuração do espaço, São Paulo, Dissertação de mestrado.Procam - Programa de Pós-graduação em Ciência Ambiental USP.

CECCHINI, A.;RIZZI, P. (2001) Is urban gaming simulation useful? Simulation \& Gaming, v. 32, n. 4, p 507-521.

COLL,C. (1996) Os professores e a concepção construtivista. In: COLL,C et al.(1996) $O$ construtivismo na sala de aula. São Paulo, Ática.

COVRE, M.L.M.(1991) O que é cidadania, São Paulo, Brasiliense.

CRAPS, M. (2003) Social Learning in River Basin Management Harmonicop WP2 Reference Document K.U. Leuven Centre for Organizational and Personnel Psychology

D’AQUINO, P. et al (2003) Using Self-Designed Role-Playing Games and a Multi-Agent System to Empower a Local Decision- Making Process for Land Use Management: The SelfCormas Experiment in Senegal. Journal of Artificial Societies and Social Simulation, U.K., v.6, n.3. 
DARÉ, W. (2005) Comportements des acteurs dans le jeu et dans la réalité : indépendance ou correspondance? Analyse sociologique de l'utilisation de jeux de rôles en aide à la concertation. Paris, 332p. Tese de Doutorado - ENGREF, CEMAGREF.

DARÉ,W. (2003) A role-playing game in irrigated system negotiation: between play and reality. Journal of Artificial Societies and Social Simulation, U.K., v. 6, n.3.

DASGUPTA, S. (2003) The role of controlled dynamic process environments in group decision making: an exploratory study. Simulation \& Gaming, v.34, n.1, p.54-68.

DEMO, P. (2001) Participação é conquista: noções de política social participativa.5ed. São Paulo, Cortez. 176p.

DIAS, G.F.(1992) Educação Ambiental: Princípios e Práticas. São Paulo, Gaia.

DORN, D.S. (1989) Simulation Games: one more tool on the pedagogical shelf. Teaching Sociology, U.K. v.17, p. 1-18.

ELLIOT, J. (1991) A practical guide to action research In: Elliot, J. Action research for educational change Open University Press, p. 69-89.

ETIENNE, M. (2003) Sylvopast: a multiple target role-playing game to assess negotiation processes in sylvopastoral management planning. Journal of Artificial Societies and Social Simulation, [S.I.] v.6, n. 2,p.1-27.

FAIRCHILD, T. (2004) O discurso de escolarização do RPG. São Paulo, Dissertação de mestrado - Faculdade de Educação USP.

FISHER, R.;URY, W.(1994) Como chegar ao sim: negociação de acordos sem concessões. 2ed. Rio de Janeiro, Imago. 216p.

FJERMESTAD, J. (1997) Proceedings of the 30th Hawaii International Conference on System Sciences: Information Systems Track-Collaboration Systems and Technology. IEEE Computer Society. Washington DC, EUA Experimental studies of group decision support systems: an assessment of variables studied and methodology. v.2, 45p.

FREIRE, P. (2005) Pedagogia do oprimido.41 ed. Rio de Janeiro, Paz e Terra.213p.

FREIRE, P. (2002) Extensão ou comunicação ?.12 ed. Rio de Janeiro, Paz e Terra. 93p.

FREIRE, P. (1996) Pedagogia da Autonomia, saberes necessários à prática educativa. São Paulo, Paz e Terra.

FREIRE, P. (1992) Pedagogia da esperança: um reencontro com a pedagogia do oprimido.11ed. Rio de Janeiro, Paz e Terra. 245p. 
FUSP (2002) Plano da Bacia do Alto Tietê. Mapa do crescimento demográfico da RMSP. Comitê de Bacia do Alto Tietê. São Paulo. Fundação Universidade de São Paulo.

FUSP (2002). Plano da Bacia do Alto Tietê, Fusp: Sao Paulo.

GUIMARÃES, M. (2004) Educação Ambiental Crítica. In: LAYRARGUES, P.P. (coord) Identidades da educação ambiental brasileira. Brasília, MMA. 156p.

HUIZINGA, J.(2001) Homo ludens o jogo como elemento da cultura. 5ed. São Paulo, Editora Perspectiva, 243p.

INSTITUTO PÓLIS (2002) Estatuto da Cidade guia para implementação pelos municípios e cidadãos: Lei n. 10.257, de 10 de julho de 2001, que estabelece diretrizes gerais da política urbana. 2ed. Brasília 273p. (Série fontes de referência.Legislação, n.46)

JACOBI, P.; KECK, M.(2003) Alto Tietê In: JOHNSSON, R.M.F. (org) Projeto Marca d'Água: seguindo as mudanças na gestão das bacias hidrográficas do Brasil: caderno 1: retratos $3 \mathrm{X} 4$ das bacias pesquisadas.Brasília.Finatec, 212p.

JACOBI, P.(2001) Gestão participativa de Bacias Hidrográficas no Brasil e os desafios do fortalecimento de espaços públicos colegiados. Revista Organização e Sociedade.São Paulo,v.8,n.22,p. 91-106

JACOBI, P. (2000) Cidade e meio ambiente: percepções e práticas em São Paulo. São Paulo, Annablume, 191p.

JACOBI, P.(1996) Ampliação da Cidadania e Participação- desafios da democratização da relação Poder Público- Sociedade Civil no Brasil.Tese de Livre Docência Parte I - cap. 1- FE-USP

JOLLIVET, M.; PAVÉ,A. (1997) O meio ambiente: questões e perspectivas para a pesquisa. In: Vieira, P.F.; Weber, J. (orgs) Gestão de recursos naturais renováveis e desenvolvimento: novos desafios para a pesquisa ambiental. São Paulo, Cortez

JUNQUEIRA, R. (1999) Desafio das Águas: articulando a agenda XXI do pedaço. Trabalho apresentado em ISTR - LAC Chile

KISHIMOTO, T.M. (1993) Jogos tradicionais infantis: o jogo, a criança e a educação. 2ed. Petrópolis, Vozes. 127p.

LAYRARGUES, P.P. (1999) A resolução de problemas ambientais locais deve ser um tema-gerador ou a atividade-fim da educação ambiental? In: REIGOTA, M. (1999) (org) Verde cotidiano: o meio ambiente em discussão. Rio de Janeiro, DP\&A 152p.

LEONARDI, M.L. (1996) Educação Ambiental e teorias econômicas: primeiras aproximações In: ROMEIRO, A.; REYDON, B.P.; LEONARDI, M.L. (orgs). Economia 
do meio ambiente: teoria, políticas e a gestão de espaços regionais. Campinas, Unicamp IE.384p.

LIMA, G. (2005) Formação e dinâmica do campo da educação ambiental no Brasil: emergência, identidades, desafios. Tese de doutorado.UNICAMP

LIMA, G. F.C.(2002) Crise ambiental, educação e cidadania: os desafios da sustentabilidade emancipatória. In: LOUREIRO, C.F.B.; LAYRARGUES, P.P. (orgs) Educação ambiental: repensando o espaço da cidadania. 2ed. São Paulo, Cortez.

LOUREIRO, C.F. (2004) Educação Ambiental Transformadora In: LAYRARGUES, P.P. (coord) Identidades da educação ambiental brasileira. Brasília, MMA. 156p.

LUDKE, M.(1986). Pesquisa em educação: abordagens qualitativas. São Paulo, EDU, 1986.

MACEDO, L. et al (2005) Os jogos e o lúdico na aprendizagem escolar. Porto Alegre, Artmed. 110p.

MACEDO, L. et al (2000) Aprender com jogos e situações-problema. Porto Alegre, Artmed.

MACEDO, L. et al (1997) Quatro cores, senha e dominó: oficinas de jogos em uma perspectiva construtivista e psicopedagógica. São Paulo, Casa do Psicólogo.

MARCATTO, A. (1996) Saindo do quadro. São Paulo, Marcatto.

MARTINS, C. E. (2001). A gestão da água em São Paulo - O feito e o a fazer. Apresentado no I Congresso Estadual de Comitês de Bacias Hidrográficas de São Pedro, SP.

MATURANA, H.; VARELA, F. (2001) A árvore do conhecimento: as bases biológicas da compreensão humana. São Paulo, Palas Athena.288p.

MAUREL, P.(2003) Some Methodological Concepts to analyse the role of IC-tools in Social Learning Processes. IEMSS www.iemss.org/iemss2004/pdf/dss2/maursome.pdf

MAYER, I. DEJONG, M. (2004) Combining GDSS and Gaming for Decision Support. Group Decision and Negotiation, Netherlands,v.13, p.223-241.

MORIN, E. (2004) A religação dos sabers: o desafio do século XXI. 4 ed. Rio de Janeiro, Bertrand Brasil. 588p.

MORIN, E. (1989) Ciência com consciência. Madrid, Anthropos Editorial

MOTA, S.R.(1997) Roleplaying game: a ficção enquanto jogo. Rio de Janeiro, 364p. Tese de doutorado - PUC-Rio, Departamento de Letras. 
PAHL-WOSTL, C.; HARE, M. (2004) Processes of Social Learning in Integrated Resources Management. Journal of Community \& Applied Social Psychology, [S.I.]. v.14, p.193-206.

PAHL-WOSTL, C.(2002) Towards sustainability in the water sector - the importance of human actors and processes of social learning Aquatic Sciences, Dubendorf Alemanha, v. 64 p.394-411.

PAVÃO, A, (2000) Aventura da leitura e da escrita entre mestres de Roleplaying Games $(R P G)$. São Paulo, Devir. 231p.

PETERS, V., VISSERS,G (2004) A simple classification model for debriefing simulation games. Simulation \& Gaming, [S.I.] v.35, n.1, p.70 - 84

PIAGET, J. (1930) Os procedimentos da educação moral, V Congresso Internacional de Educação Moral In: Macedo, L. (org) (1996) Cinco estudos de Educação Moral São Paulo, Casa do Psicólogo (Coleção psicologia e educação).

PON (1995) Program On Negotiation at Harvard Law School, www.pon.org

PORTO,M.(2003) Recursos hídricos e saneamento na região metropolitana de São Paulo: um desafio do tamanho da cidade. Brasília: Banco Mundial (Série Águas Brasil, v. 3)

REIGOTA, M. (1999) (org) Verde cotidiano: o meio ambiente em discussão. Rio de Janeiro, DP\&A 152p.

REIGOTA, M. (1994) O que é educação ambiental. São Paulo, Brasiliense

ROLNIK, R. (2003) A cidade e a lei: legislação, política urbana e territórios na cidade de São Paulo. 3.ed. São Paulo, Studio Nobel: FAPESP. 242 p.

ROLNIK,R.(2002)Estatuto da cidade: guia para implementação pelos municípios e cidadãos: Lei n.10257 de 10 de julho de 2001, que estabelece diretrizes gerais da política urbana. Brasília: Câmara dos Deputados, Coordenação de Publicações .

SAITO, C.H.(2002) Política nacional de educação ambiental e construção da cidadania: desafios contemporâneos In: Ruscheinsky, A.(org) Educação ambiental: abordagens múltiplas. Porto Alegre.

STEINWACHS, B. (1992) How to facilitate a Debriefing. Simulation \& Gaming, v.32, n.2, p.186-195

SILVA, D.J. (2000) Método da Educação Ambiental Brasileira. In: Pelicioni, M.C.; Philippi Jr, A. (eds) Educação ambiental: desenvolvimento de cursos e projetos. São Paulo, Signus editora. 
SORRENTINO, M. (2002) Desenvolvimento sustentável e participação: algumas reflexões em voz alta. In: LOUREIRO, C.F.B.; LAYRARGUES, P.P. (orgs) Educação ambiental: repensando o espaço da cidadania. 2ed. São Paulo, Cortez.

SORRENTINO, M. (1998) De Tbilisi a Thessaloniki, a educação ambiental no Brasil. In: CASCINO, F; JACOBI, P., OLIVEIRA, J.F. (orgs) Educação, meio ambiente e cidadania. Reflexões e experiências. São Paulo, SMA/CEAM. 122p.

TASSARA, E.T. (2001) Propostas para a instrumentalização de uma educação ambiental transformadora. In: COSTA, L.; TRAJBER, R. (orgs) Avaliando a educação ambiental no Brasil: materiais audiovisuais, São Paulo, Peirópolis: Instituto Ecoar para a Cidadania.

THIOLLENT, M. (1986) Metodologia da pesquisa-ação. São Paulo, Cortez.

TRAJBER, R.(1996) Avaliando a Educação Ambiental no Brasil: materiais impressos. São Paulo, Gaia. 225p.

TUNG, L.; TURBAN, E. (1998) A proposed research framework for distributed group support systems. Decision Support Systems, [S.I.], v.23, p.175 - 188.

ULRICH, M. (1997) Games / Simulations about environmental issues existing tools and underlying concepts. In: Gaming/Simulation for Policy Development and Organizational Change. Proceedings of the 28th Annual International Conference of the International Simulation and Gaming Association (ISAGA) Tilburg pp. 301-311

VIEZZER, M. (org) (1994) Manual Latino-americano de Educ-Ação ambiental. São Paulo, Gaia.

WECHSLER, M.P.F. (1999) Psicodrama e construtivismo: uma leitura psicopedagógica. São Paulo, Annablume. 256p. 